\title{
التفسير الصوتي لبعض مظاهر اللحن في العربية المعاصرة
}

\author{
الاكتور \\ عمر عبد المعطي أبو العينين \\ أستاذ العوم اللنوية المساء المعاد \\ كلية التربية - جامعة المنصورة
}


$-00 .-$ 


\section{المقدمة}

الحمد لله رب العالمين والصلاة والسلام على سيدنا محمد النبى وآله أجمعين، وبعد.

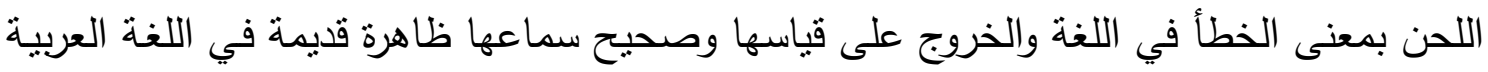

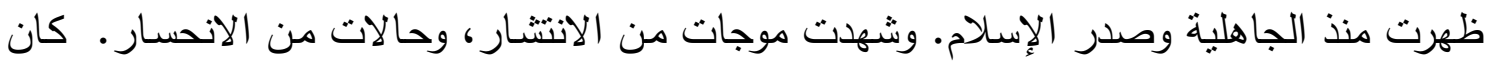

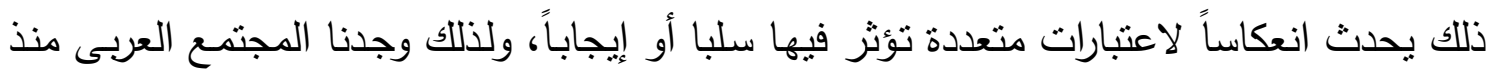

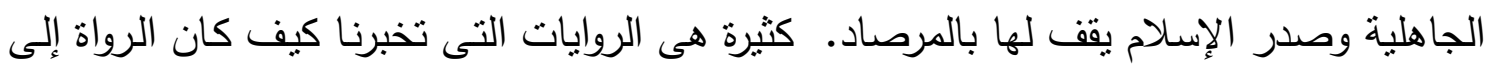

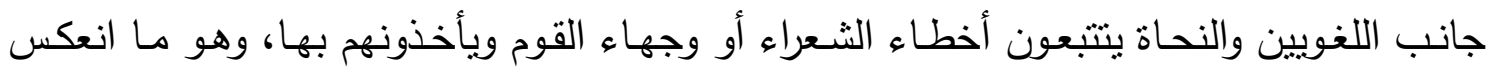

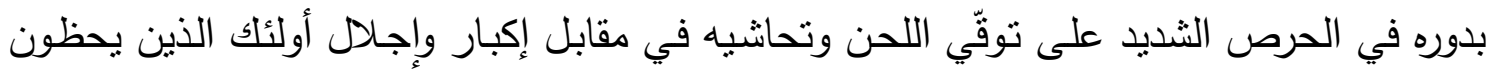

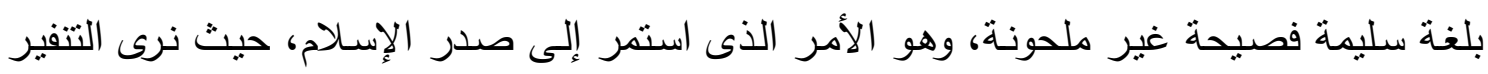

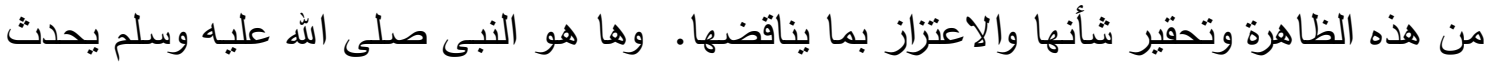

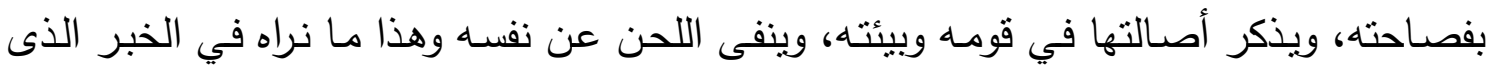

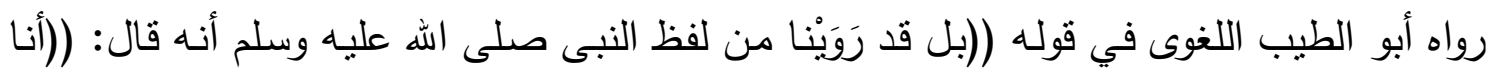

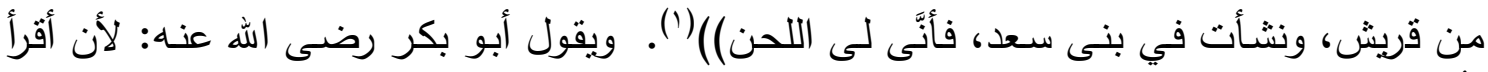

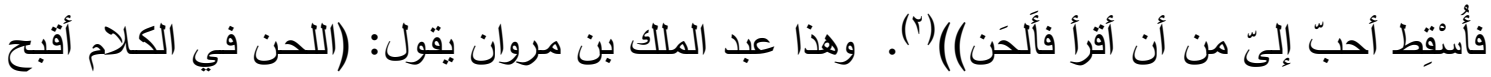

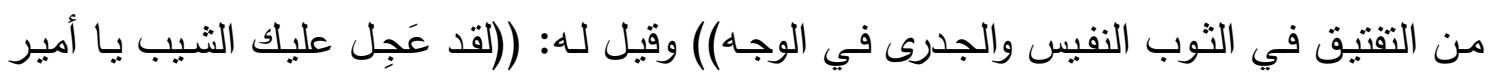

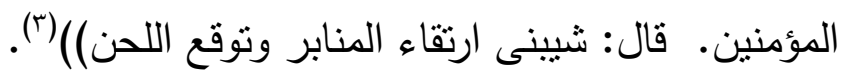

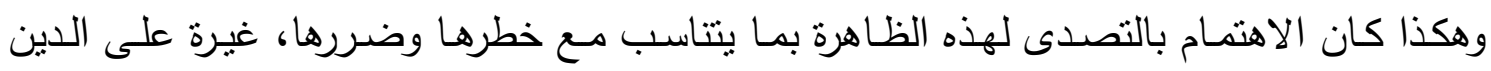

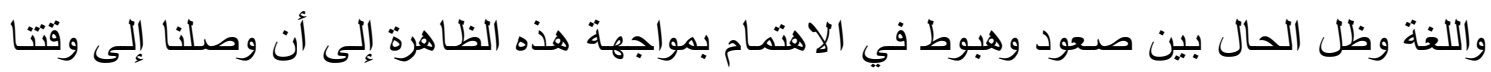

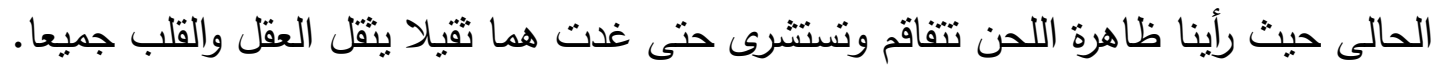

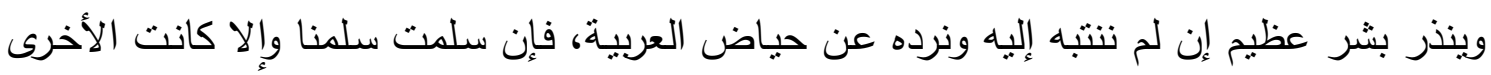

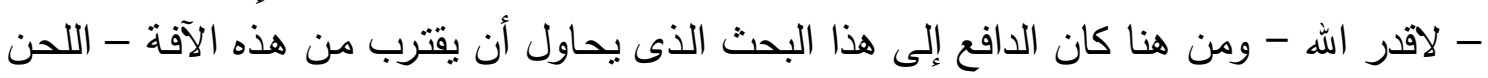

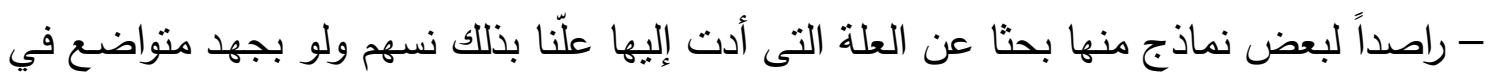

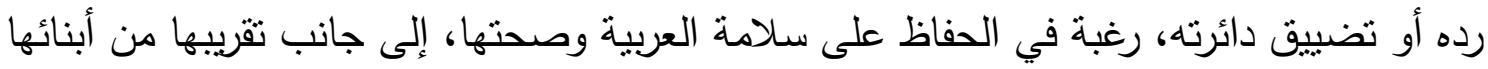

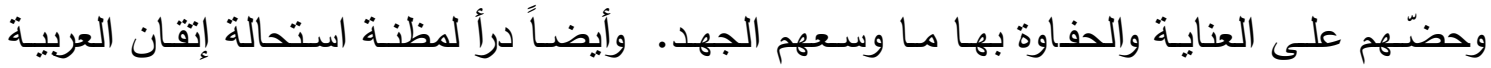

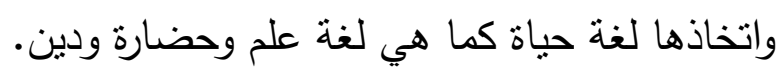

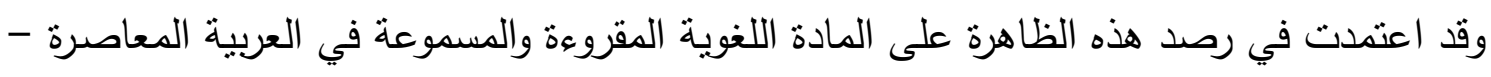

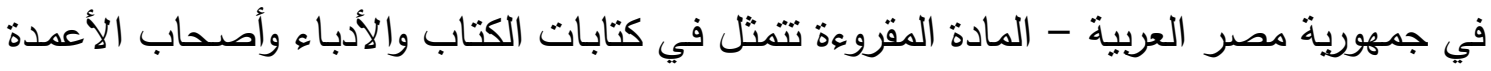

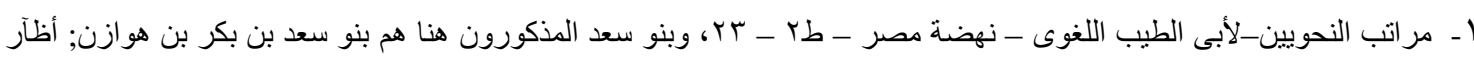

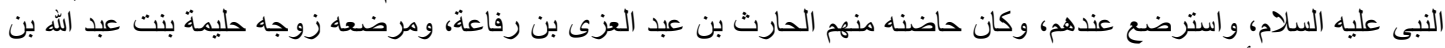

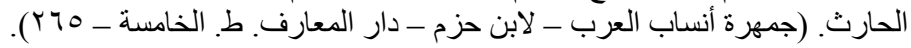

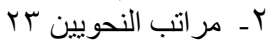

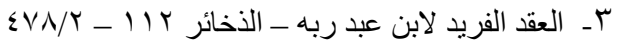




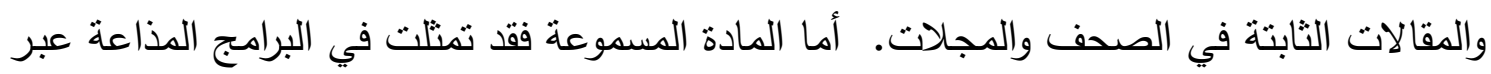

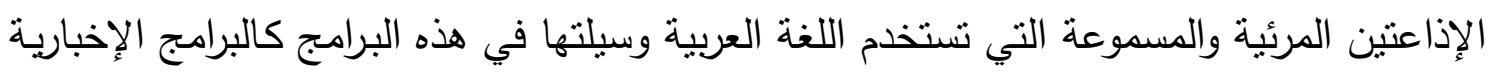

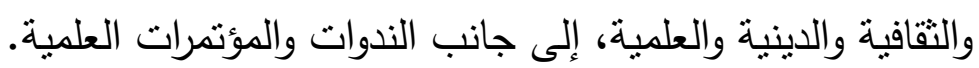

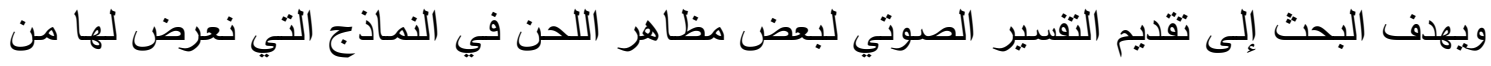

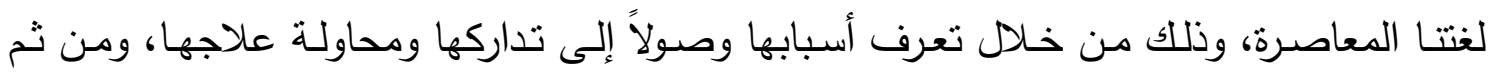

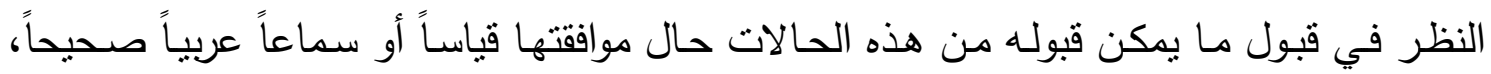

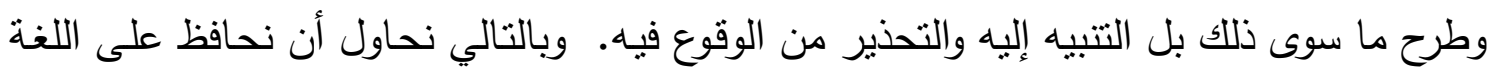

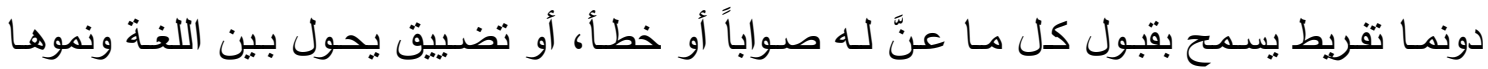

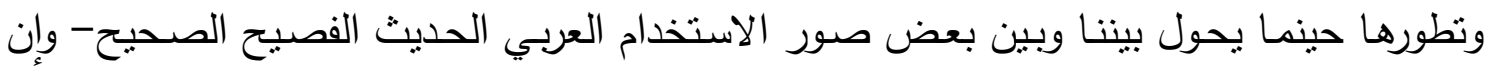

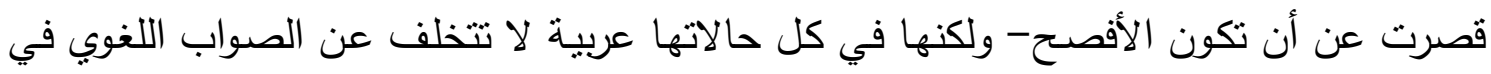

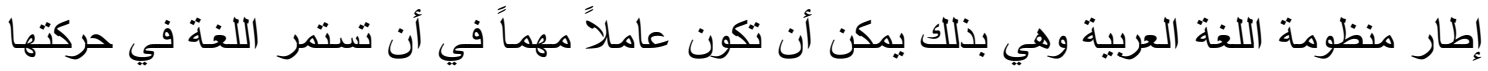
النشطة نحو النمو والتطور . وقد قامت خطة البحث على تتاول محاور ثلاثة هي:

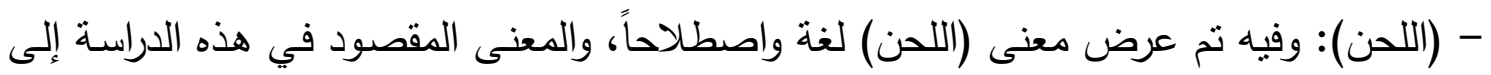
جانب مناقثة كيف بدأ اللحن وكيف كان حتى انتهى إلينا الآن.

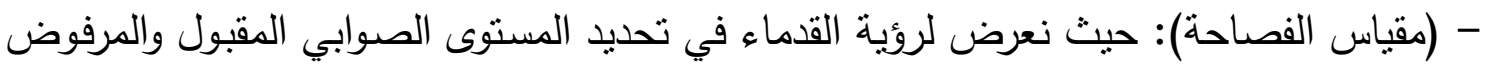

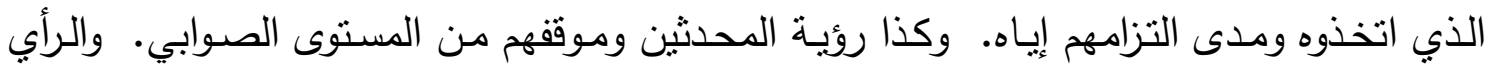
الذي نراه في ذلك.

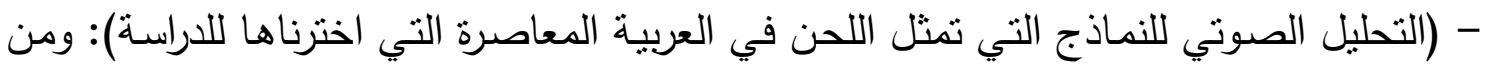

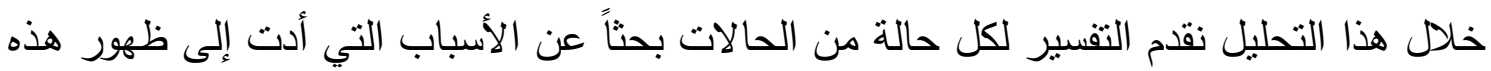

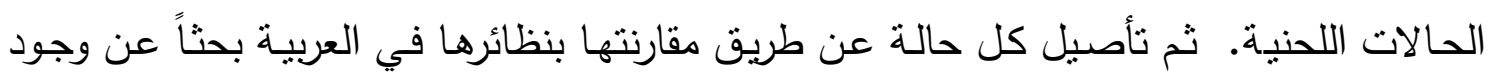

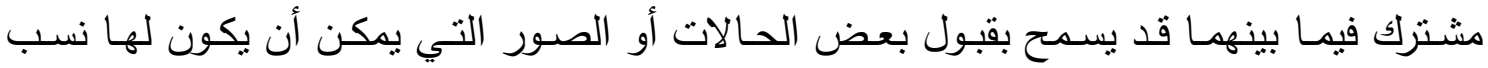

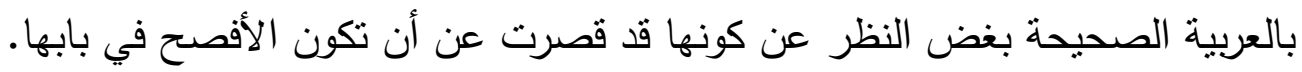

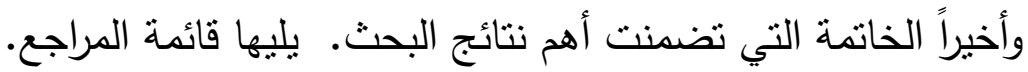
واله ولي النوفيق إنه ولي ذللك والقادر عليه. ولله الحمد في الأولى والآخرة. 


\section{اللحن}

يتتاول هذا البحث التفير الصوتي لبعض مظاهر اللحن في العربية المعاصرة وهو ما يستدعي بداية تحديد مفهوم (اللحن) المقصود في هذه الدراسـة، وبخاصـة إذا علمنا أن لكلمة (اللحن) عدة معان ودلالات. وهو ما أثنار إليه صاحب اللسان فيما رواه عن ابن بري في قوله: "قال ابن بري

وغيره للحن ستة معان الخطأ في الإعراب واللغة والغناء والفطنة والتعريض والمعني". ( ) ولعله من المفيد أن نقف أمـام كل معنى من هذه المعاني بشـئ من الإيضـاح وذلك على النحو الآتي:

ا- اللحن بمعنى الغنـاء والتطريب!: وفيـه يقول ابن فـارس: "إزالـة للكـلام عن جهته الصـحيحة بالزيادة والنقصان في الترنم".(؟) ومما بروي من شواهد هذا المعنى قول جهم بن خلف:

تنَغنَّت عليه بلحنٍ لهان ومنه أيضاً قول يزيد بن النعمان:

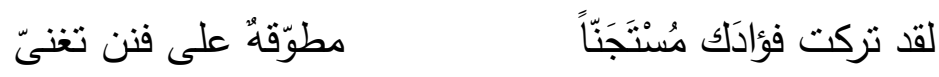

يميل بها وتركبُه بِلحنِ ץ- اللحن بمعنى التعريض والإيماء: ومن شواهد هذا المعنى قول القتّال الكلابي:

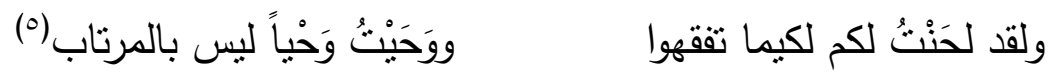
ومنه كذلك قول مالك بن أسماء بن خارجة الفزارى في جارية له:

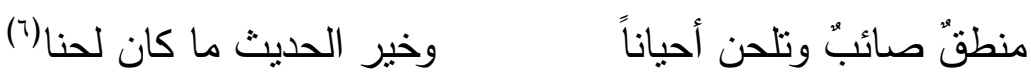

r- اللحن بمعنى اللغة أو اللهجة الخاصـة: يقول الزمخشري: "يقال هذا ليس من لحني، ولا من لحن قومي، أي من نحوي وميلي الذي أميل إليه وأتكلم به، يعني لغته" (V) ومن شواهد هذا المعنى قول الأعرابية الكلبية:

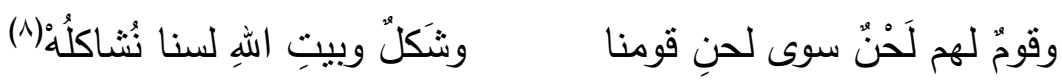
ومنه كذلك قول شريك عن أبى إسحق عن أبى ميسرة في تفسير (العرم) في قوله تعالى:

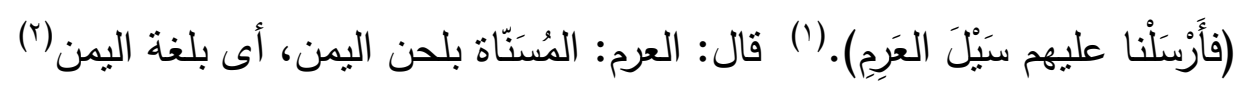

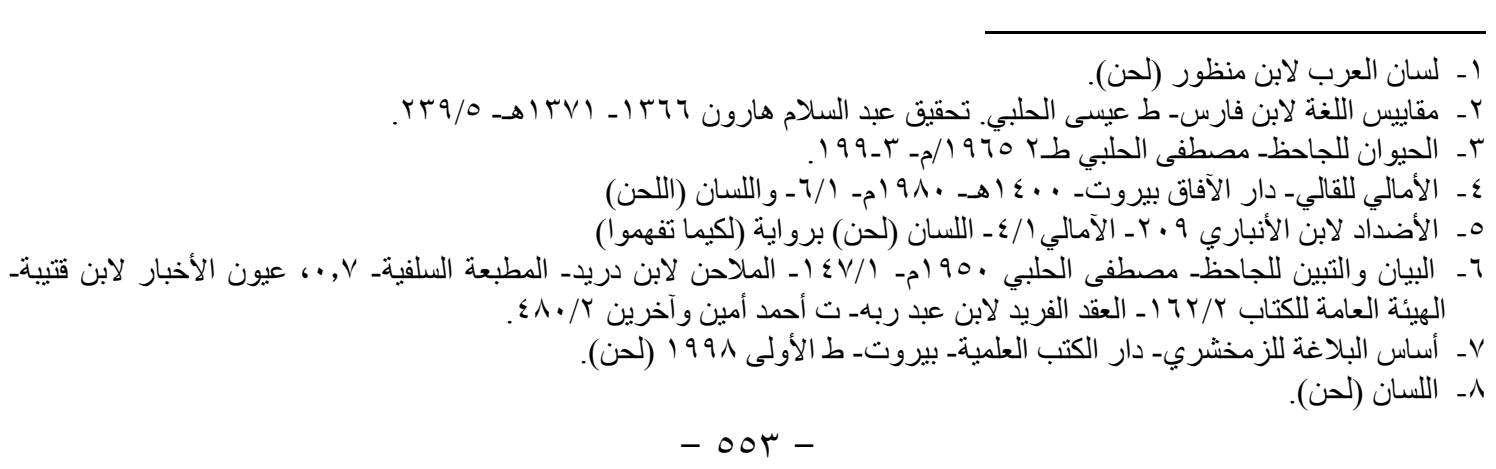


ع- اللحن بمعنى الفطنة والصواب: ومن ذلك ما جاء في أضداد ابن الأنبارى: (وقال عمر بن

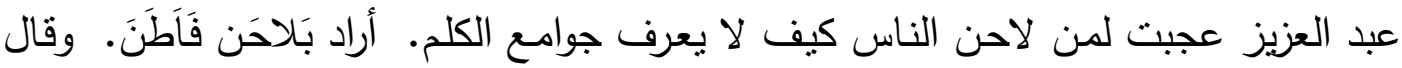
أبو العالية كان ابن عباس يعلمنا لحن الكلام وقال لبيد:

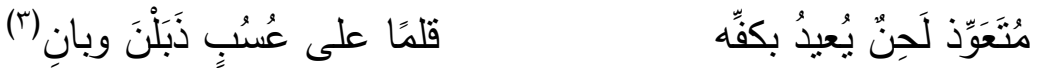

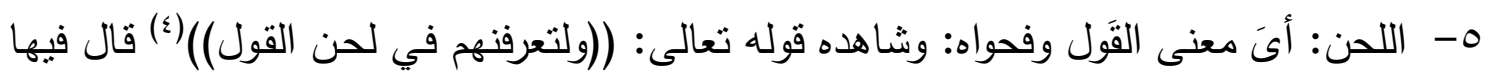

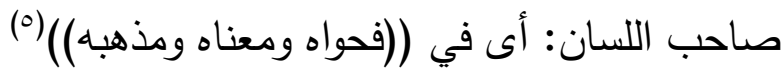

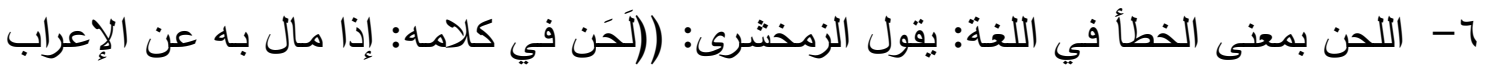

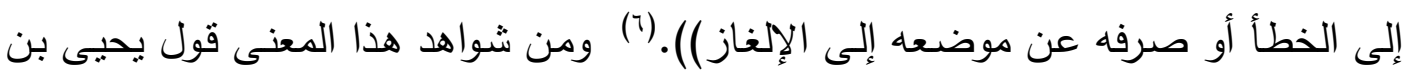

نوفل الحميرى في هجاء خالد بن عبد الله القسرى والى العراق (• ب ا-ه ـ (هـ):

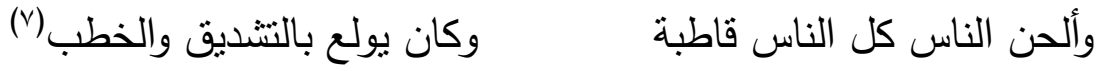

ومنه قول رؤبة بن العجاج في أرجوزته التى مدح بها بلال بن أبى بردة:

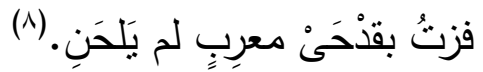

وبعد ماتقدم أقرر أن معنى اللحن المقصود في هذه الدراسة هو دلالة اللحن على الخطأ في اللغة فئة سواء أكان هذا الخطأ في أصوات اللغة أو مفرداتها أو تراكيبها أو معانيها. يقول ابن فارس: ((فأما اللحن بسكون الحاء فإمالة الكلام عن جهته الصحيحة في العربية، ويقال:

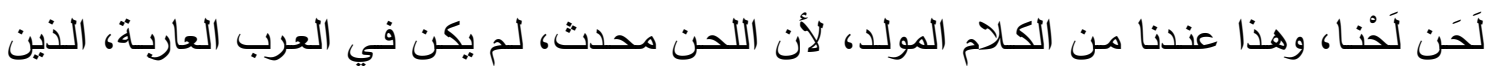

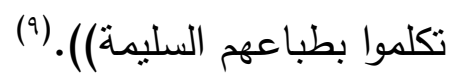

أمَّامتى انتقلت دلالة لفظ اللحن للالالة على معنى الخطأ في اللغة أو الخطأ في الكلام فهو مـا

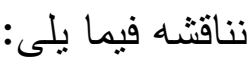
يقول يوهان فلك: "وهذا اللفظ القديم: اللحن، الذى يطلقه علماء اللغة والنحو اصطلاحا على الخطأ في اللغة، إنما اكتسب هذا المدلول نتيجة لاتفاق عرفى على تغيير معناه الأصلي في وقت متأخر

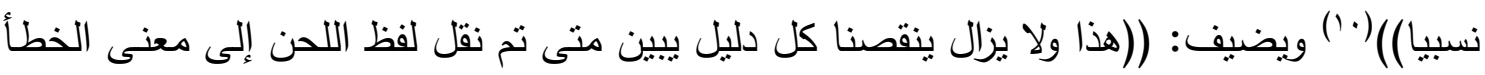

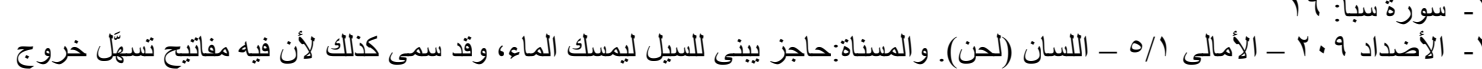

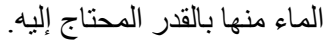

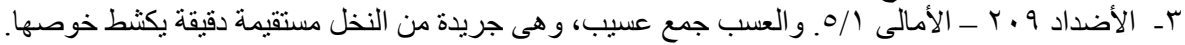

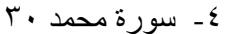

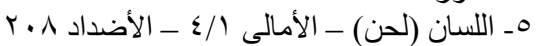

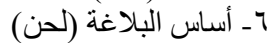

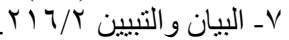

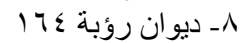

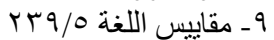

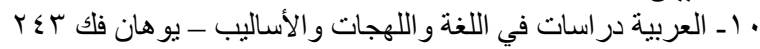


في الكلام. وأغلب الظن أنه استعمل لأول مرة بهذا المعنى عندما تتبه العرب بعد اختلاطهم

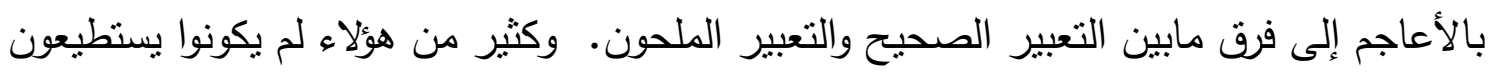
إخراج حروف الحلق والإطباق بالدقة المعروفة في العربية من مخارجها، فاستعاضوا عنها بحروف أخف على ألسنتهم وأسهل على طباعهم. وكان من أثثر هذا إلى جانب الثراء العظيم في ألفاظ

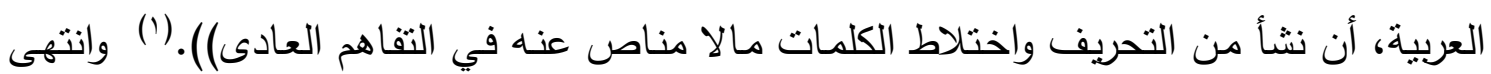

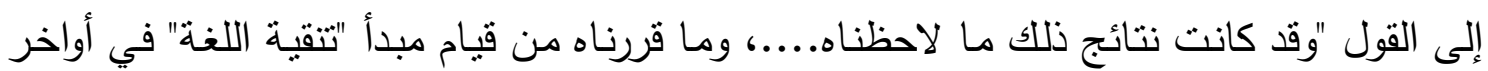

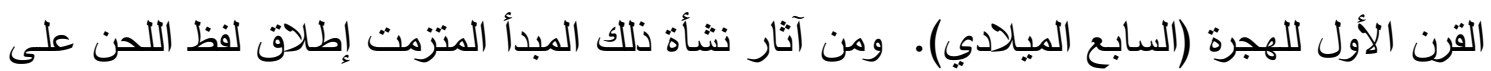

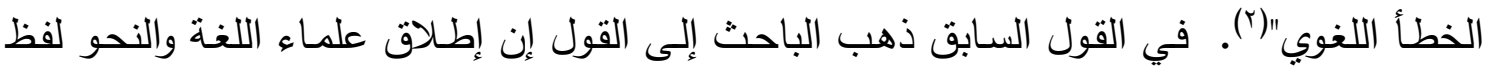

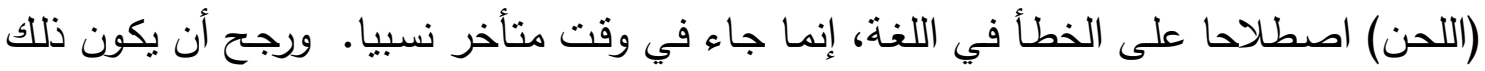

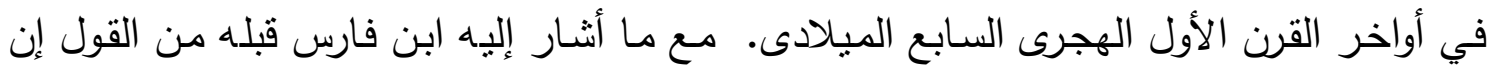

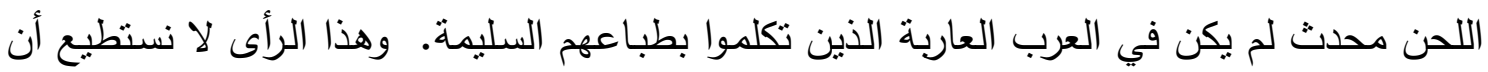
نسايره أو أن نتفق معه للأسباب الآتية: - ما ذكره أبو الطيب اللغوى في مراتب النحويين من قوله ((بل قد روينا من لفظ النبى صلى الله

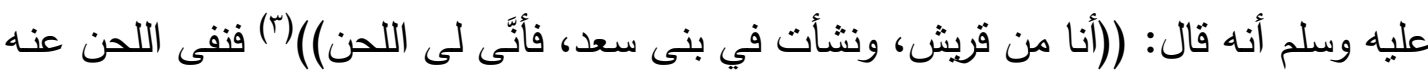

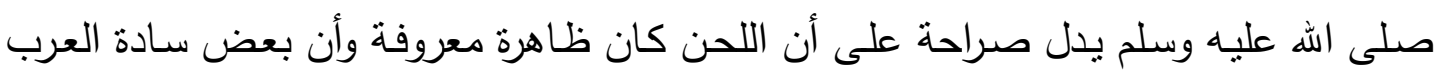

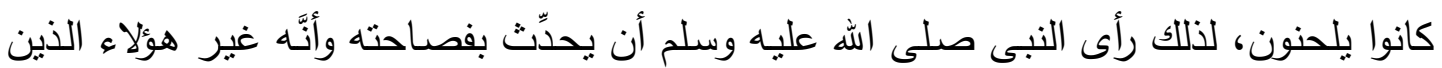
يصدر اللحن عنهم. ويقول أبو الطيب كذلك (واعلم أن أول ما اختل من كلام العرب فأحوج إلى التعلم الإعرابُ،

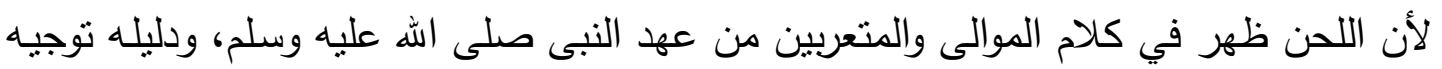

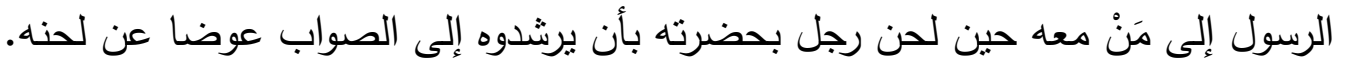

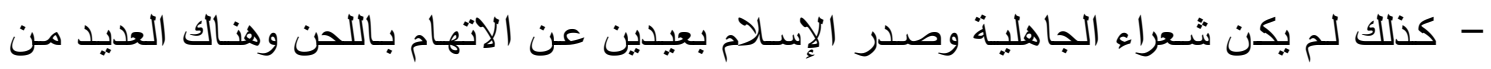

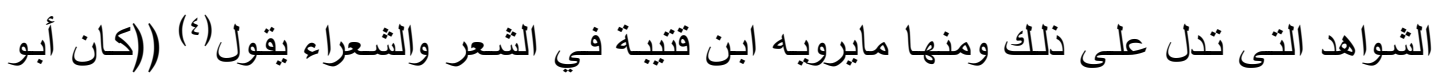
عمرو بن العلاء بذكر أن الإقواء هو اختلاف الإعراب في القوافى وذلك أن تكون قافية مرفوعة وأخرى مخفوضة، كقول النابغة في قصيدنه التى أولها: عجلان ذا زاد وغيرَ مزوَّدِ

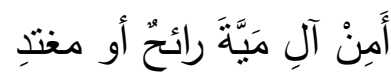




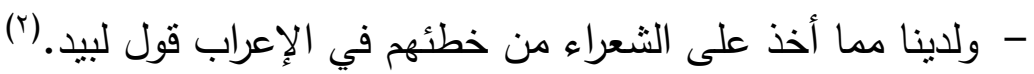

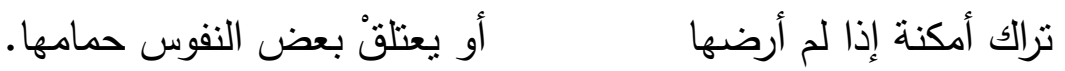
يريد: أترك المكان الذى لا أرضاه إلى أن أموت، ولا أزال أفعل ذلك. و (أوْ) هاهنا بمنزلة (حتى). وقول امرئ القيس:(四)

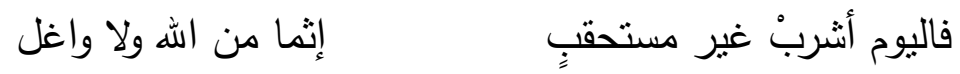
يذكرون هذا البيت ويحتجون به في تسكين المتحرك لاجتماع الحركات.

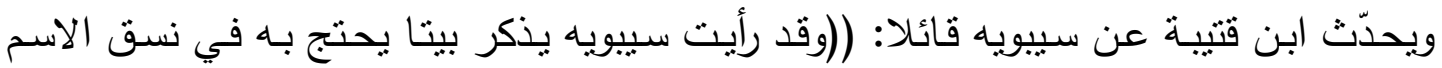

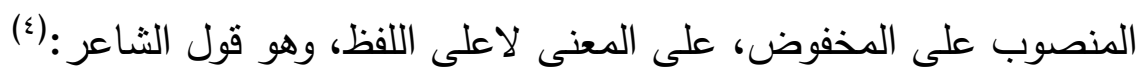

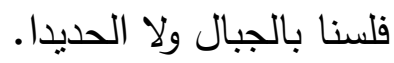

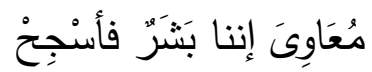

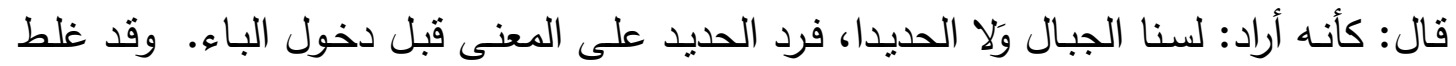

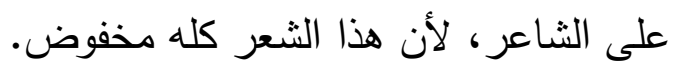
- ومن ذلك أيضا قول الفراء:

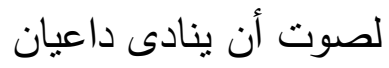

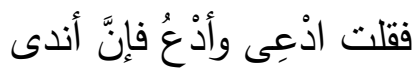
إنما هو : فقلت ادعى وأدعوَ إنّ أندى.

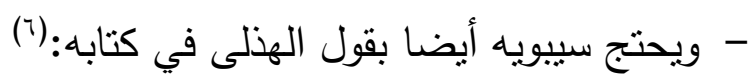

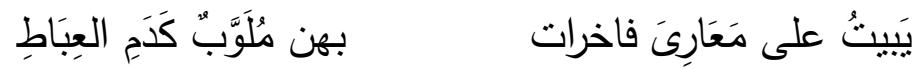

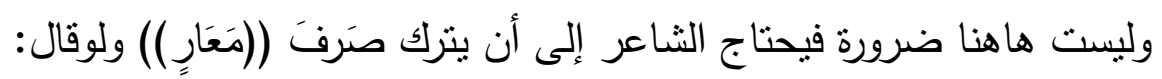

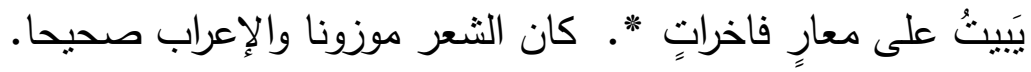

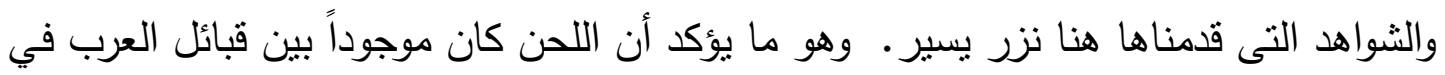

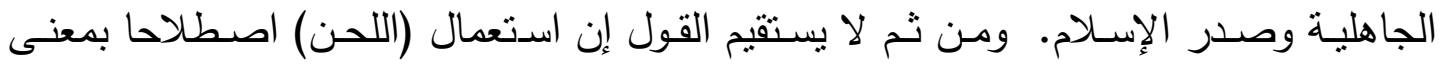
الخطأ إنما تأخر إلى نهاية القرن الأول الهجرى. أو أنه لم يكن في العرب العابع العاربة فهو قول

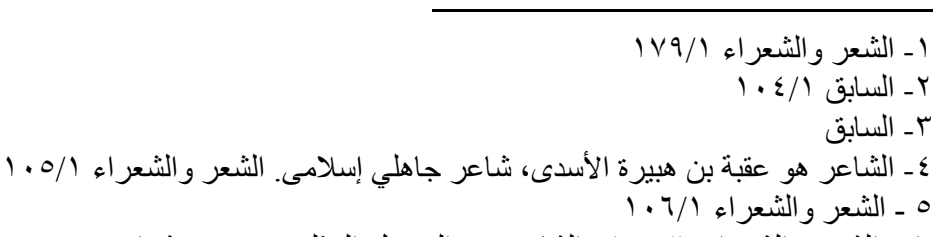

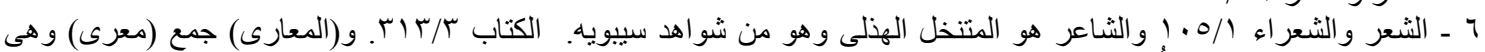

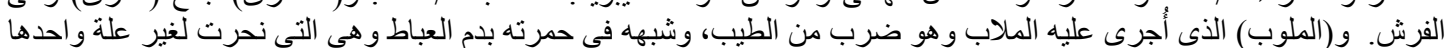


تبطله الثواهد وتتبئ بغيره ; ذلك أن قدم الظاهرة ورصدها والتتفير منها يستدعى وجود اللفظ

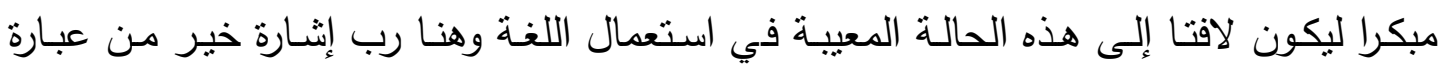

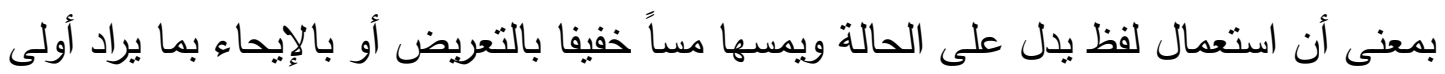
من التعبير الصارم (أخطأت). ولان ننسى أن للعرب مذاهبهم في ذلك فالدفازة بجانب البيداء.

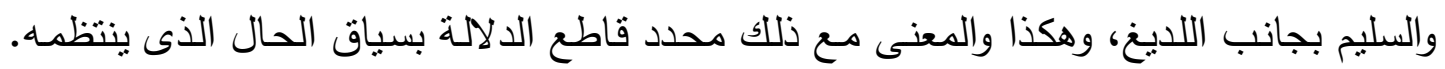

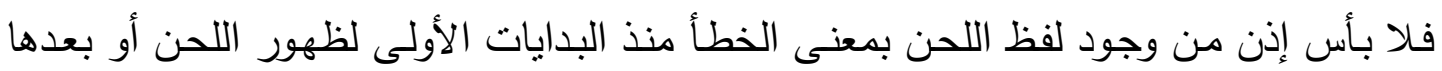
بمدى زمني قصير ، دون حاجة تدعو إلى الانتظار قرابة قرن أو يزيد حتى نستعمل اللفظ بمعناه الاصطلاحى: (الخطأ) فليس لذلك ما يبرره.

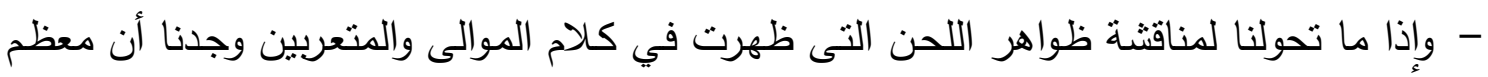

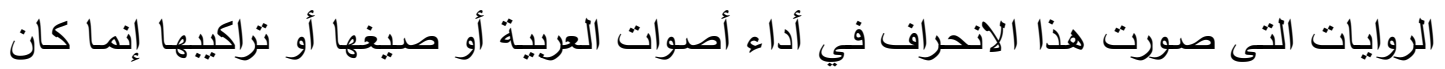
من قبل هؤلاء الموالى، ومن ذلك ما يرويه ابن قتيبة:(') (وقال فيل مولى زياد لزياد:

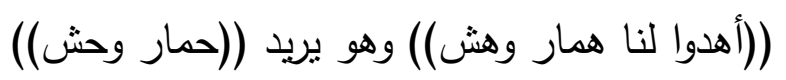

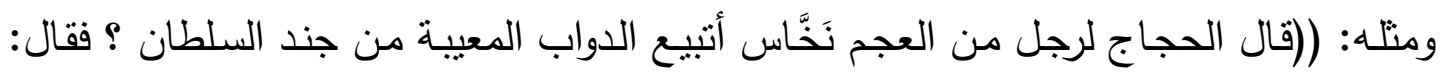

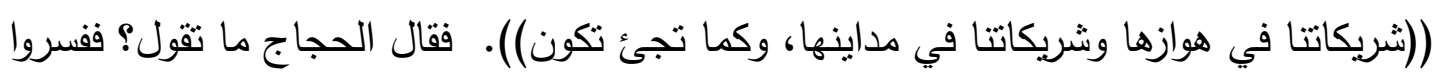

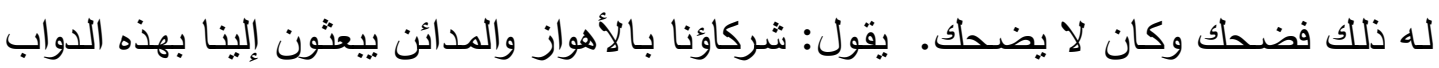

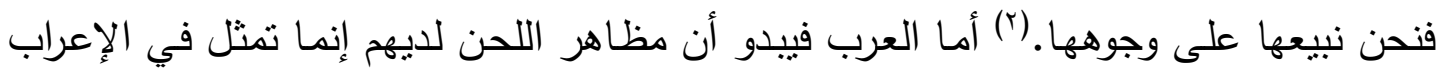

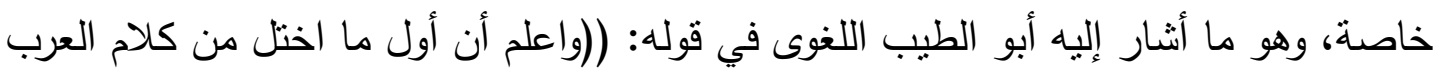

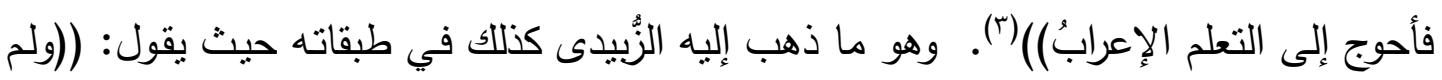
تزل العرب تتطق على سجيتها في صدر إسلامها وماضى جاهليتها، حتى أظهر الله الإنسام

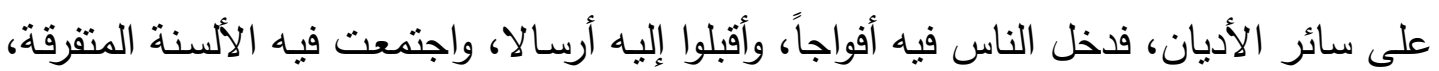

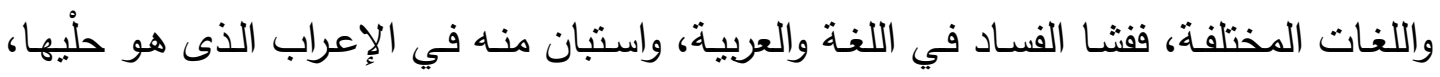

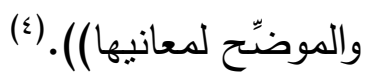
- ويروى الجاحظ: ((قالوا: وأول لحن سُمِع بالبادية: هذه عصداتى، وأول لحن سمع بالعراق حَيّ

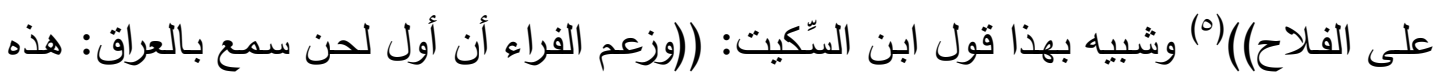

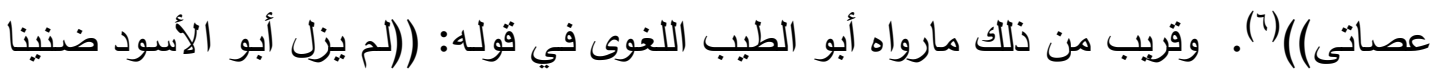


بما سمع عن عليّ عليه السلام حتى قال له زياد: قد فسدت ألسنة الناس، وذلك أنهما سمعا

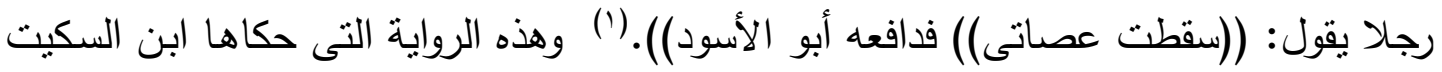

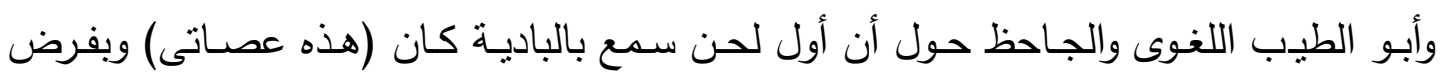
صحتها فإنها لا تحمل دليلا على أن هذا هو (أول) لحن قد سمع لأسباب نجملها في الآتى:

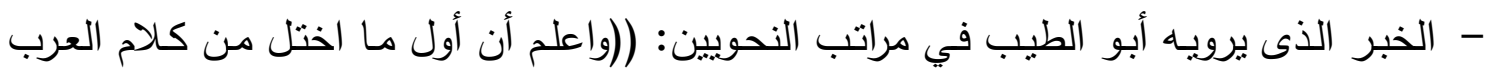
فأحوج إلى التعلم الإعرابُ.لأن اللحن ظهر في كلام الموالى والهتعربين من عهد النبى صلى الهـ

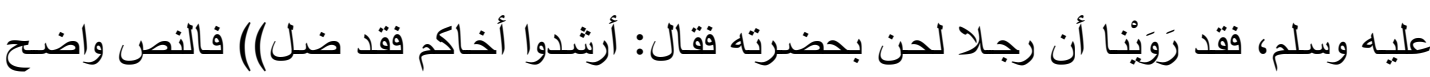
الدلالة في كون اللحن قد ظهر من ((عهد)) النبى صلى الله عليه وسلم.

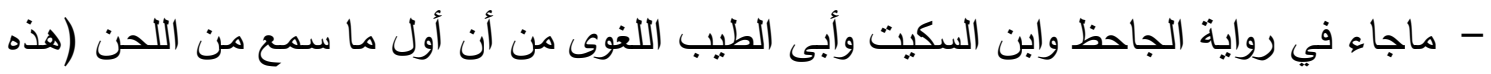

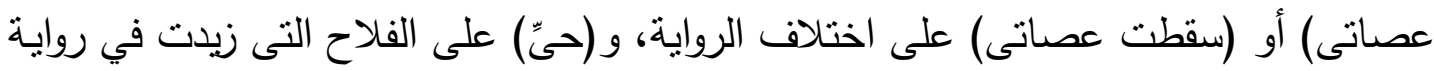

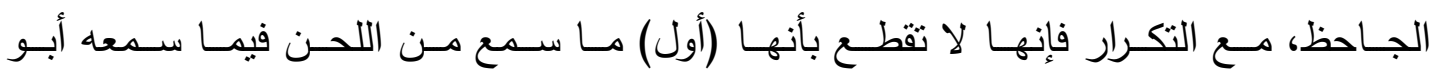

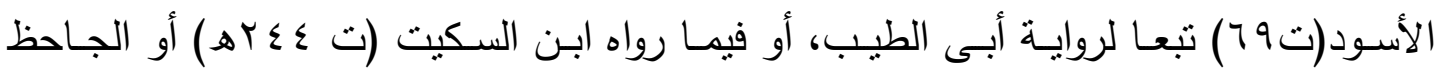

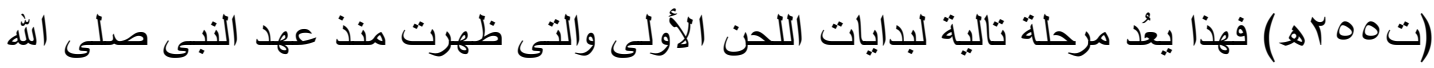

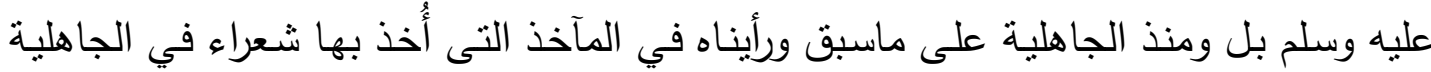

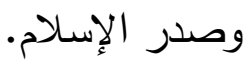

ونلحظ أيضا أن اللحن هنا في هذه الرواية لم يكن على المجمع عليه والمشهور الذى أشنارت إليه

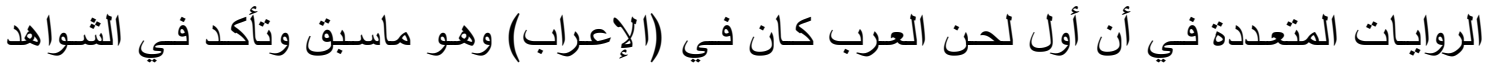

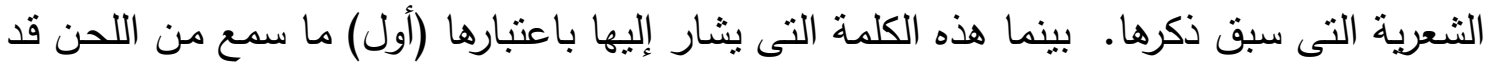

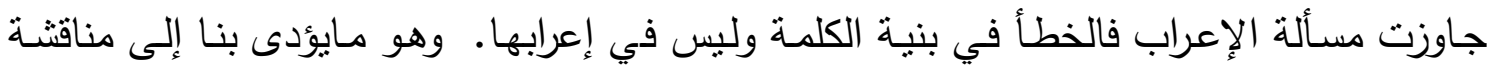

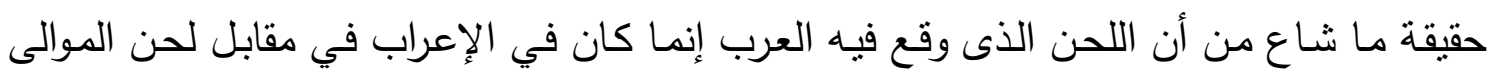

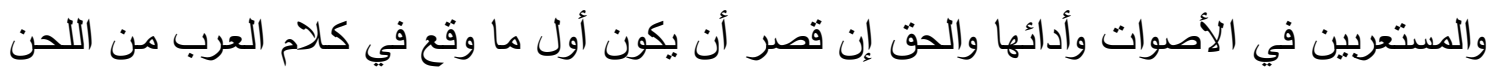

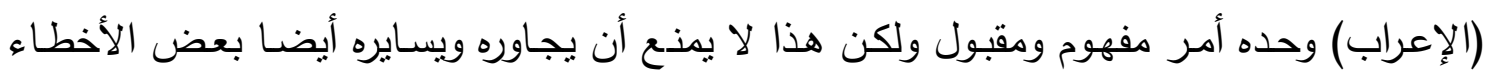
الأخرى في الأصوات وطريقة نطقها أو في عدم فهم فحوى الخطاب وهو ما يمكن أن ندلانل عليه

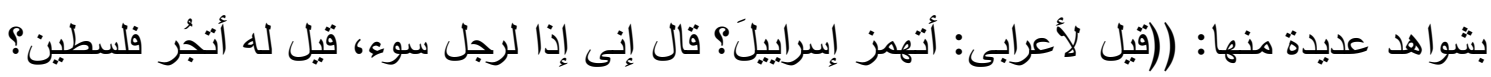
قال إنى إذاًا لقوى.

وقيل لآخر : أتهمز الفأرة؛ فقال: الهرَّة تهمزها. (؟) 


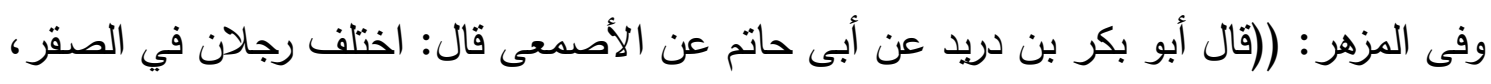

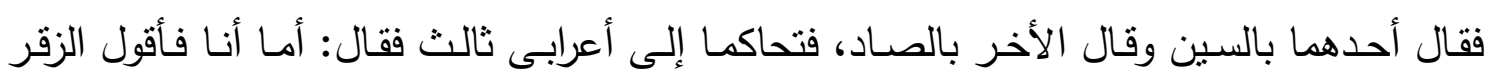

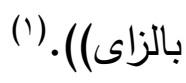

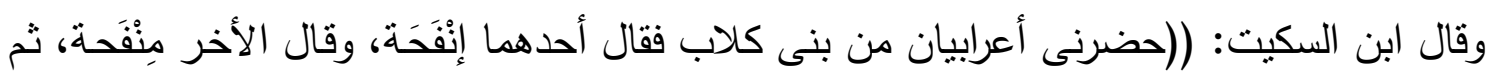

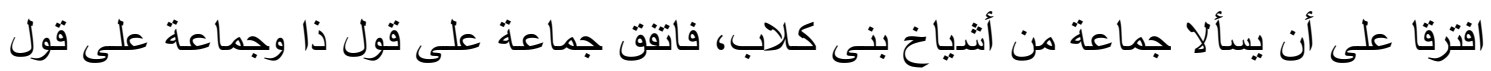

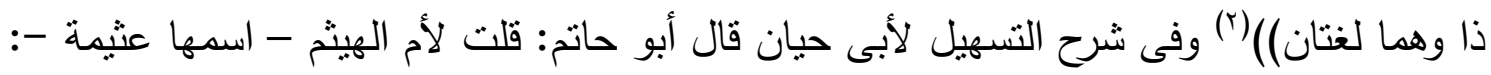

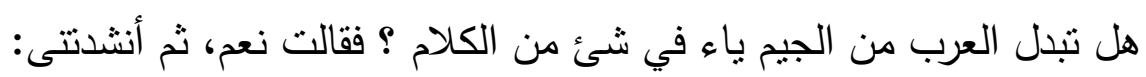

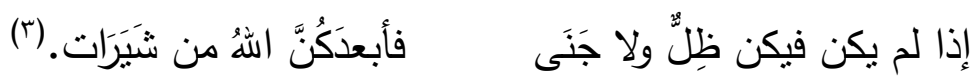

أما شواهد اللحن في الإعراب التى وقع فيها العرب فهى بدورها متعددة نذكر منها:

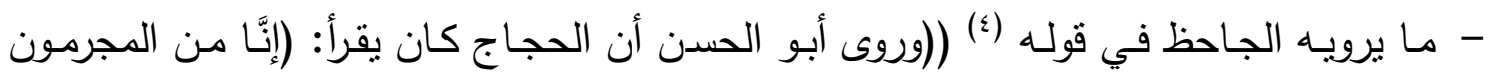

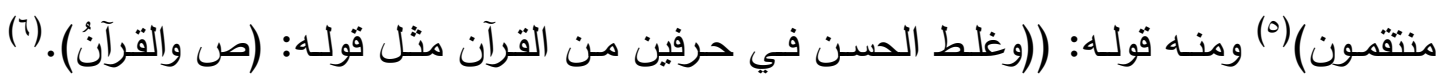

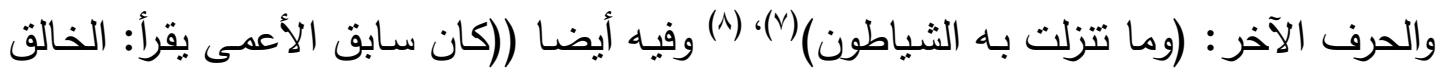

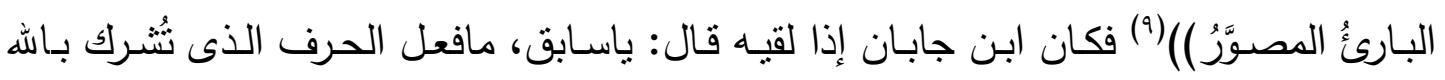

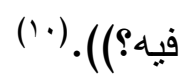
وفى عيون الأخبار يروى ((سمع أعرابى مؤذنا يقول: أثهُهُ أن محداً رسولَ الهُ بنصب رسول،

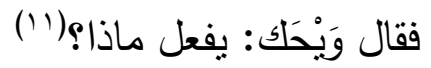
وغير ذلك كثير كثير . وما قدمته هنا قصدت من ورائه الإثارة إلى عدم دقة القول إن لحن

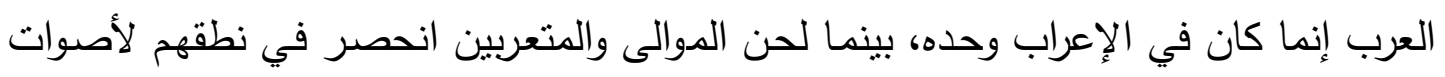

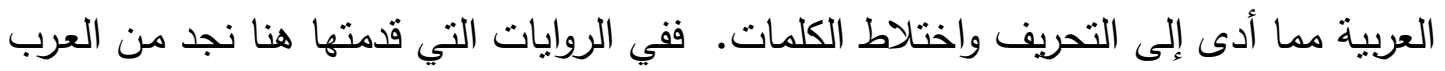

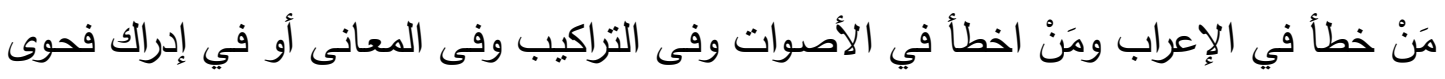

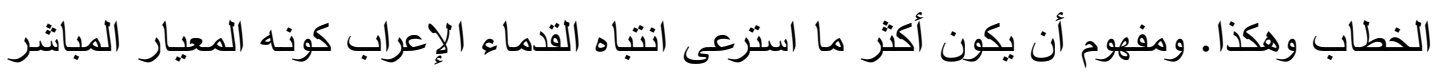

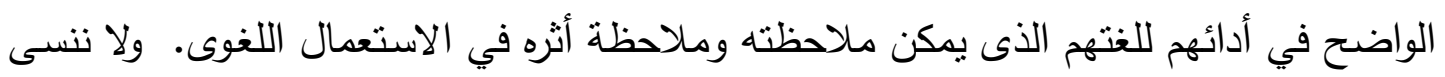

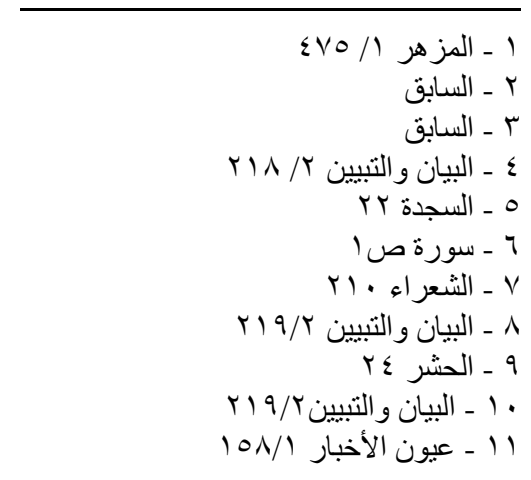




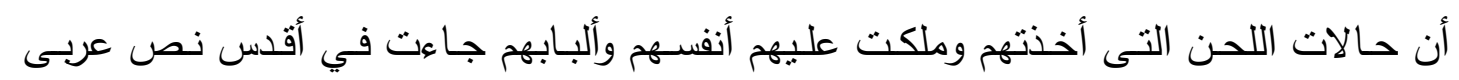

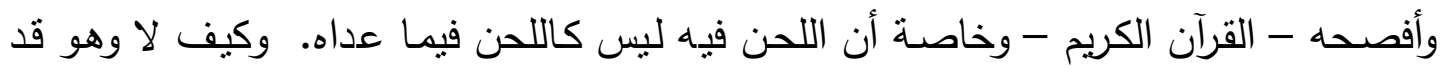

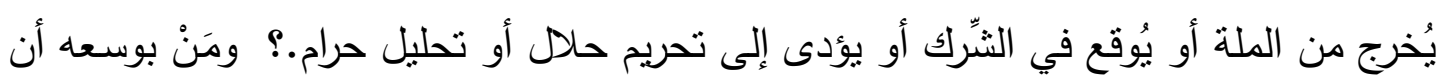
يطيق منل هذا أو يقبله؟ ومن هنا انصب اهتمامهم على الإعراب وتوارت إلى جانبه مشاهد اللحن الأخرى في الأصوات

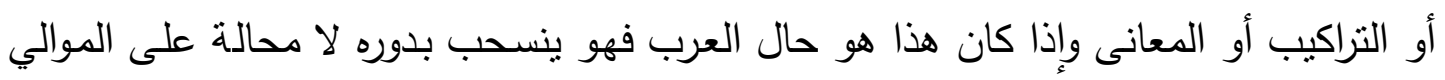

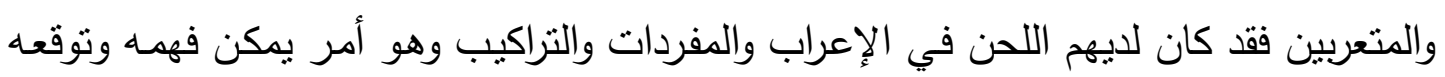

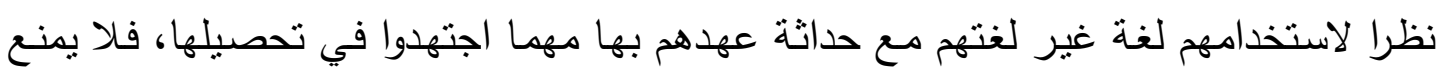

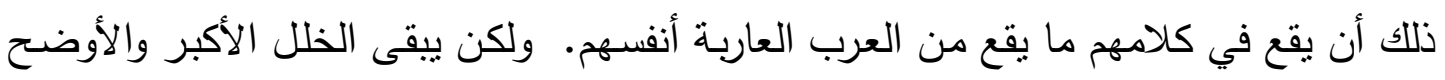

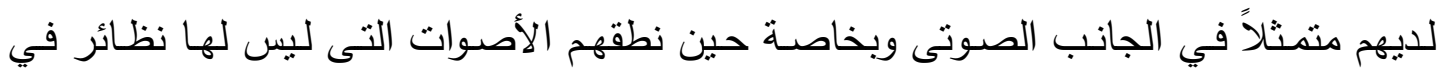

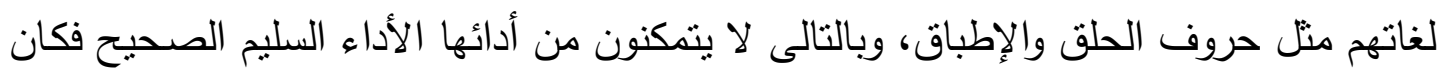

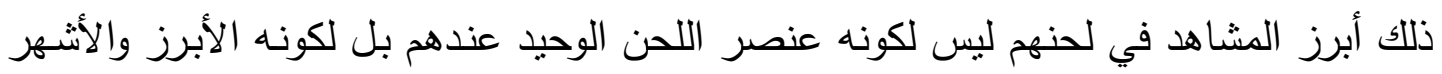
لديهم كما كان اللدن في الإعراب الأبرز والأنشهر لاعثى العرب العاربة. - وييقى لنا قبل أن نشرع في عرض التفسير الصوتى لبعض مظاهر اللحن في العربية المعاصرة

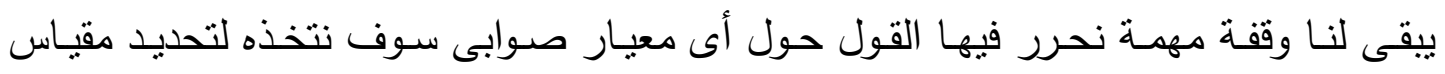

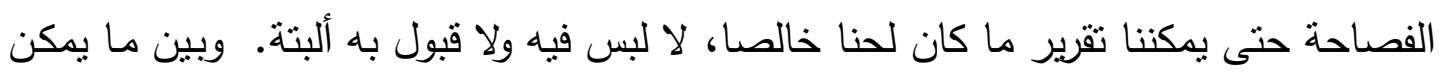

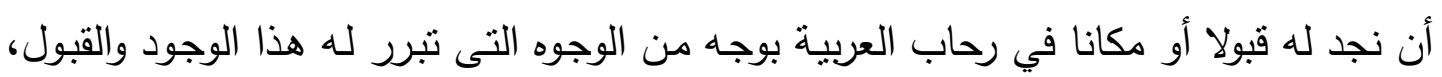

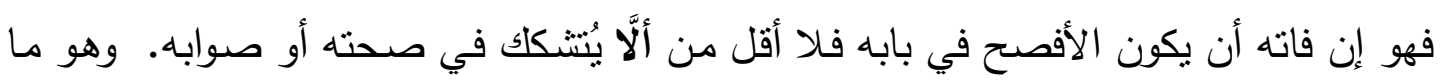
نعرض له فيما يلى. 


\section{مقياس الفصاحة (المستوى الصوابى)}

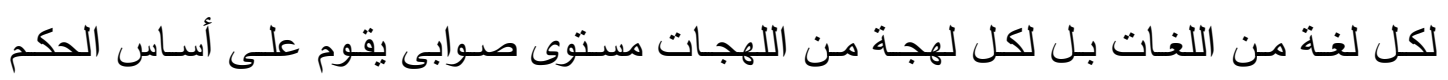

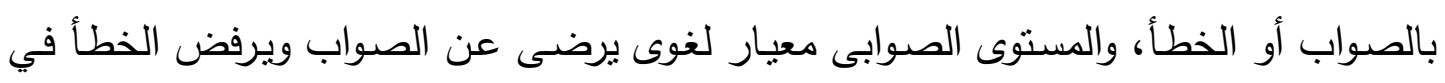

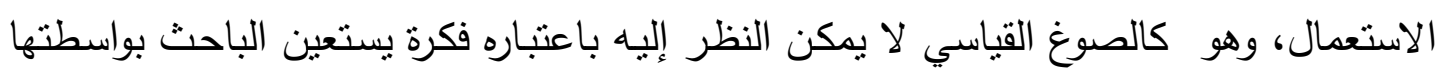

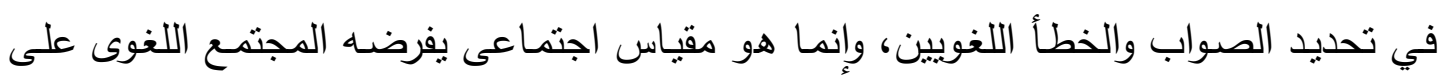

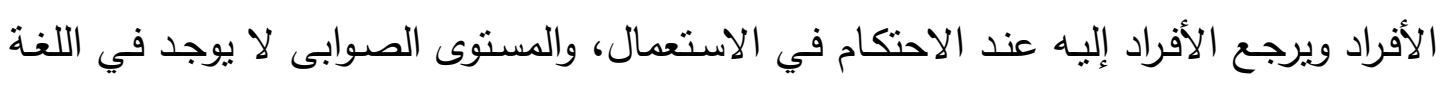

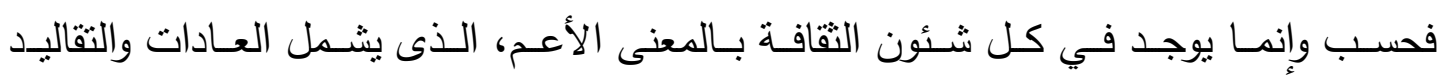

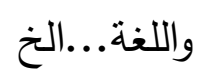

إنه مقياس عام برمقه الفرد بشىء من المهابة والاحترام ويحرسه المجتمع بأسلحة أقلها النقد

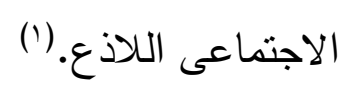

وتحديد المستوى الصوابى أمر ضرورى في كل اللغات إذ أن كثيرا من مسائل الخلاف بين لإنين

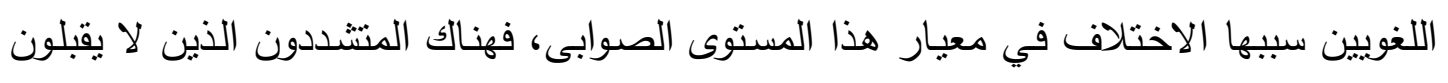

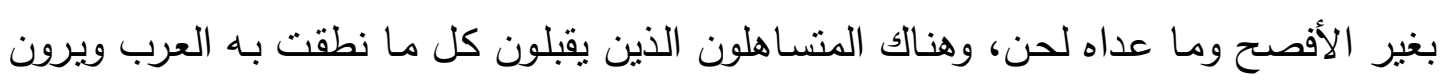

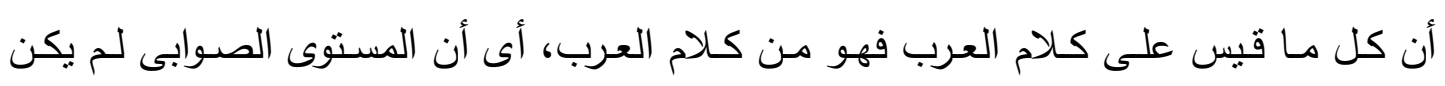

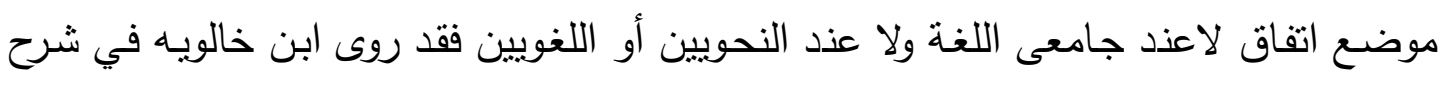

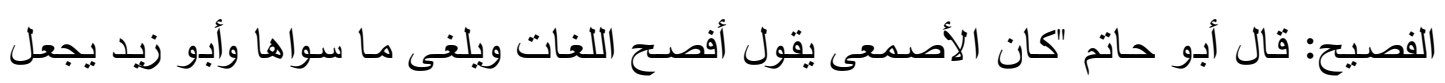

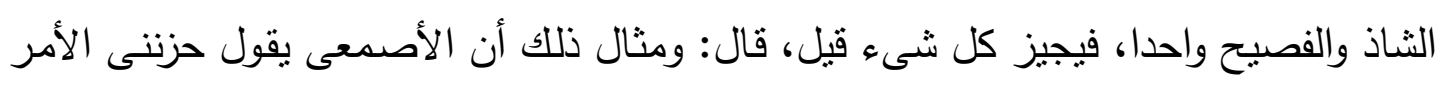

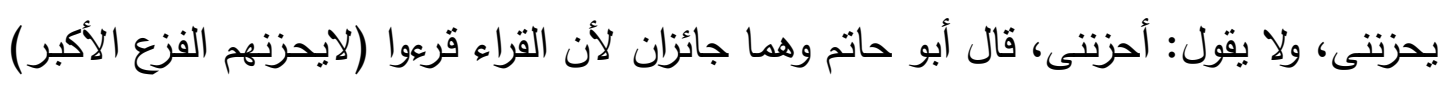

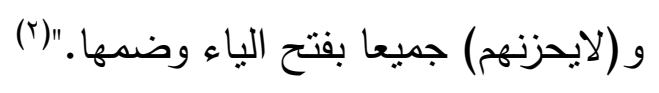

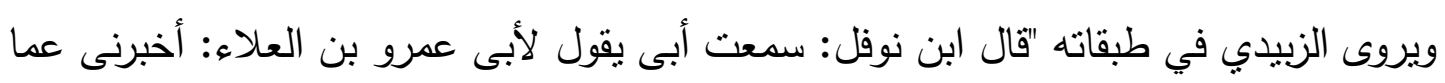

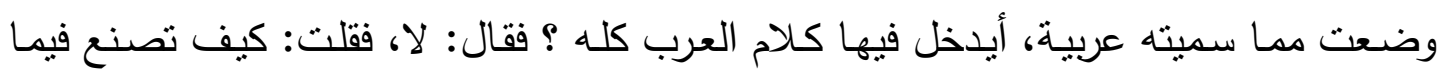

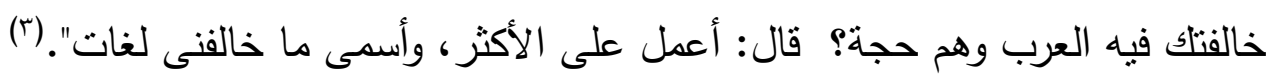

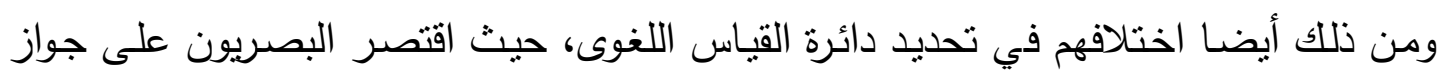

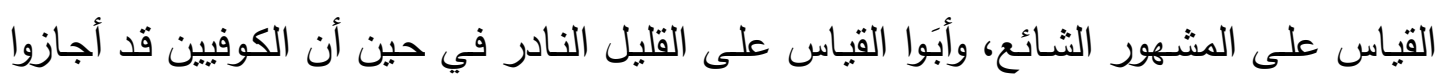

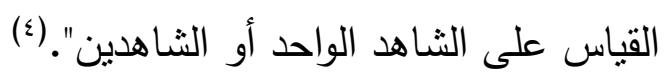

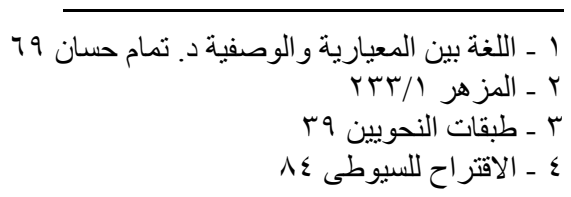




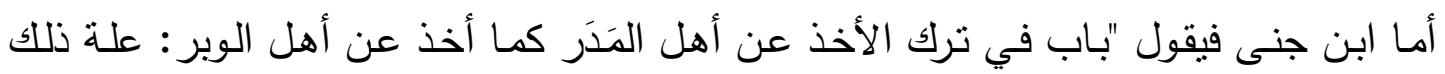

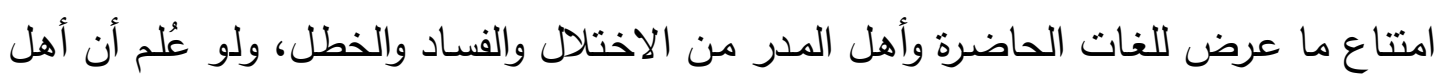

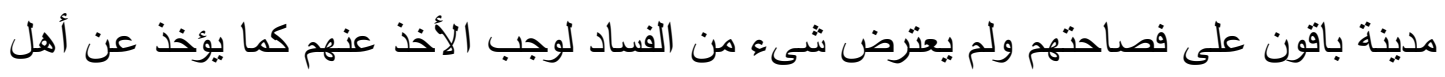

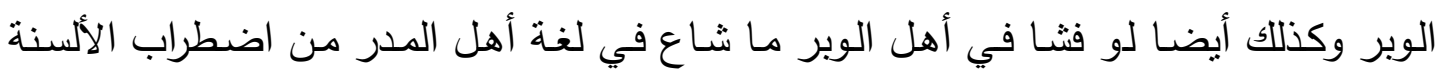

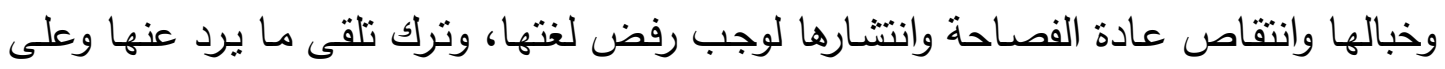

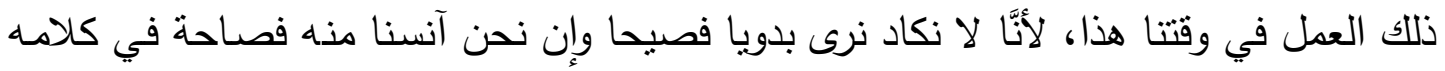

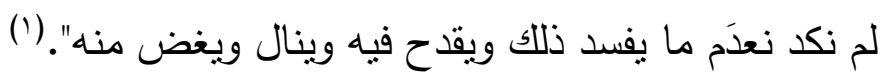

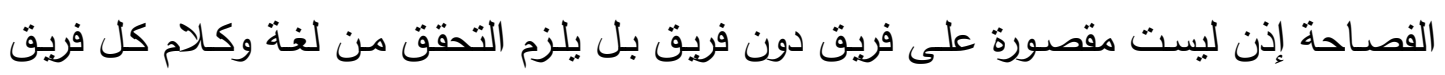

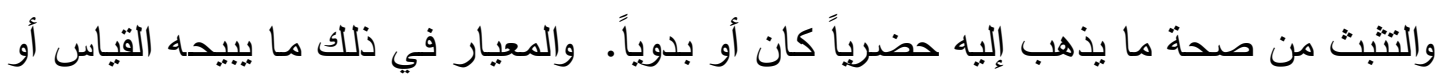

ورد بمثلكه سماع". (ץ)

ومادة اللغة العربية تتوزع بين قسمين:

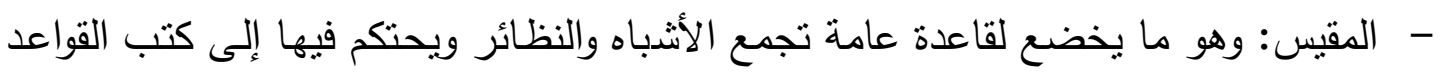

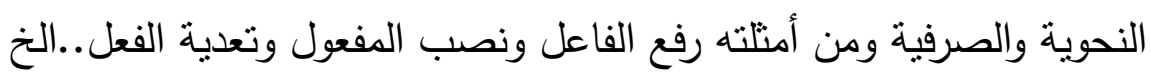

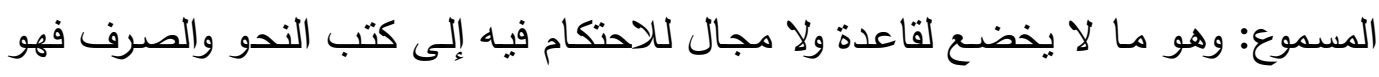

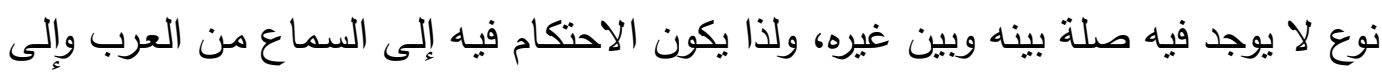

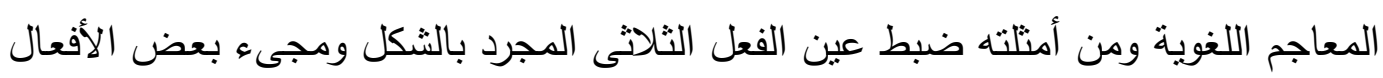
متعديا بنفسه. والفرق بين النوعين يتجلى في كون النوع الأول يمكن أن يستخدم المرء فيهه القياس دون حاجة إلى تتبع كلام العرب، وأما القسم الثانى فلا يصح فيه القياس، لئل إذ لابد في كل مثنال

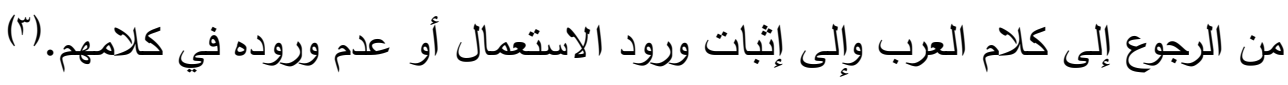

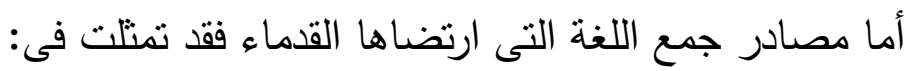

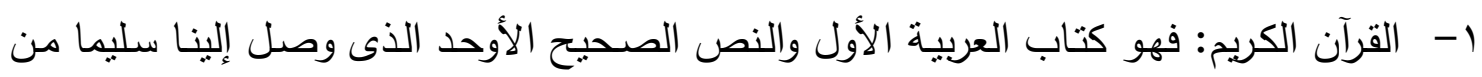

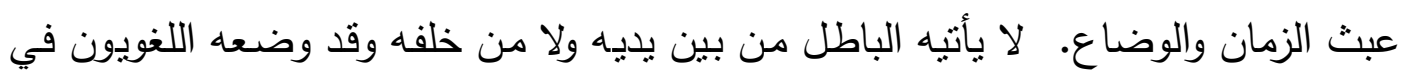
أعلى درجات الفصاحة فهو أهم وثيقة لغوية صحيحة بين أيديهم وهو خير مدنل للاطل من للغة الأدبية ولذا فموقفهم منه محسوم من حيث الاستشهاد به.

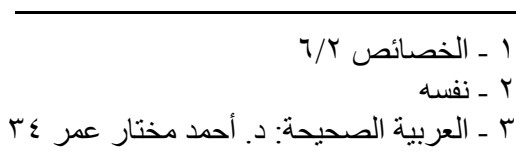


ץ- القراءات القرآنية: نظر اللغويون إليها باعتبارها أحد المصادر اللغوية المهمة وكان شرطهر

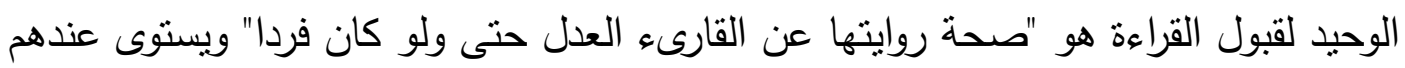

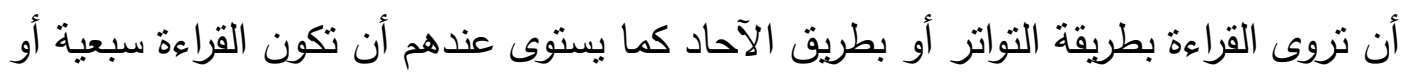

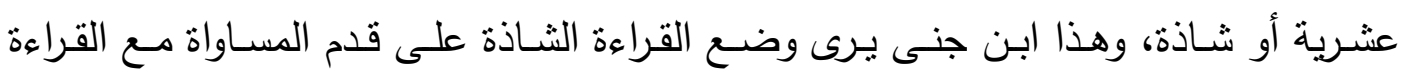

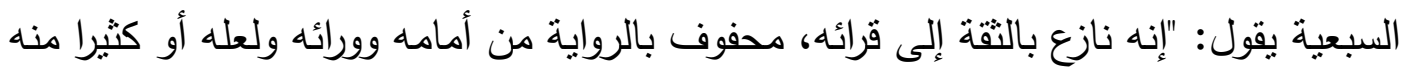

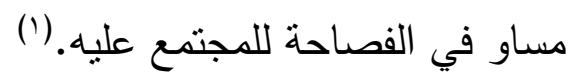

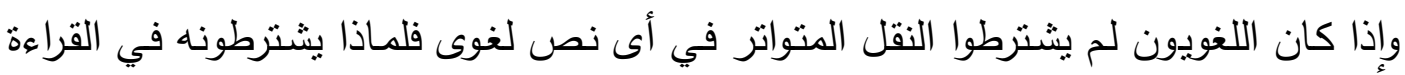

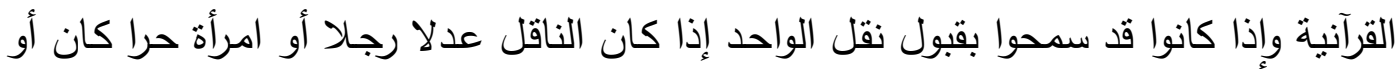

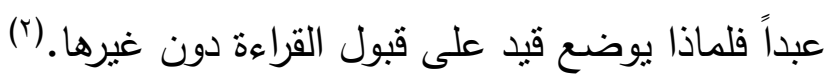

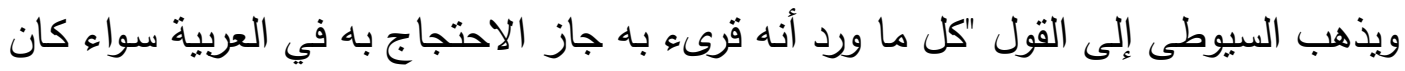

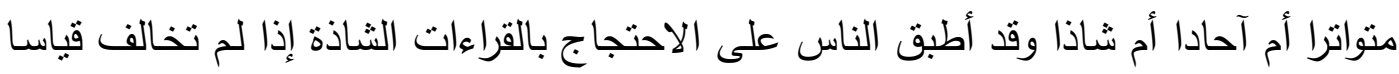

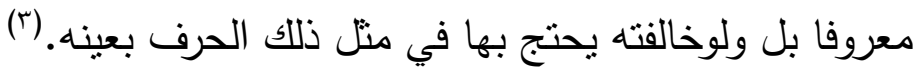
ولعله من المهم في هذا السياق التتبيه إلى أن كل المصادر اللغوية التى يتم الاعتماد عليها

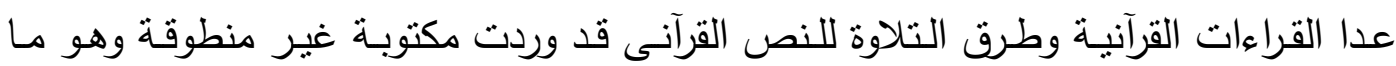

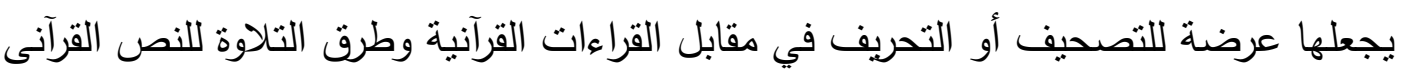
والنى تمثل النموذج الوحيد لكيفية نطق الأصوات العربية قديما وحديثا. r- الثعر العربى: وقد قسموا الثعراء إلى طبقات أربع :

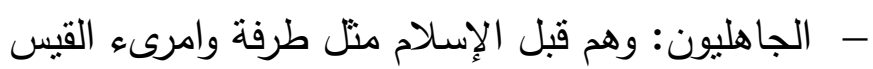

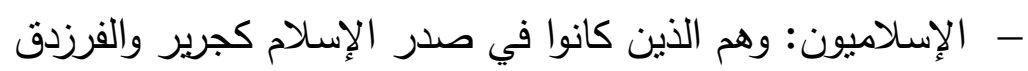

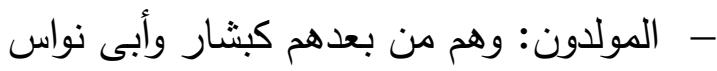

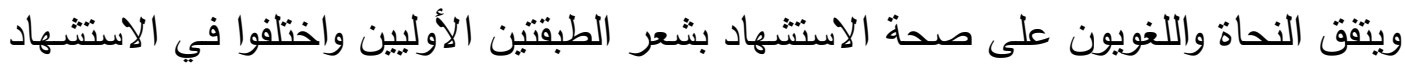

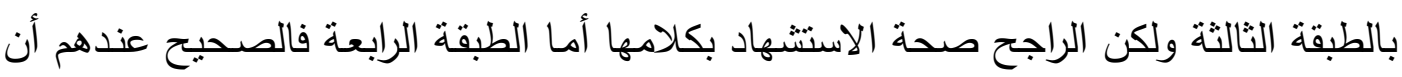
لا يستشهر بكلامها إطلاقا وإن كان بعض اللغويين مثل الزمخشرى - يحتج بطبقة المولدين

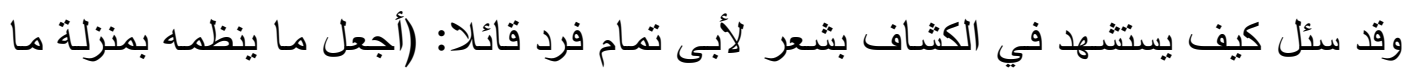

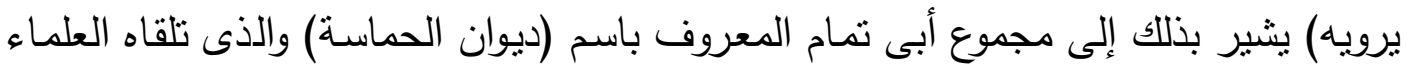

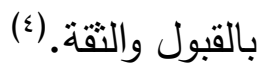


ع- - النثر العربى: لم يكن أوفر حظا من الثعر العربى إن لم يكن القيد عليه أنقل والوطأة أثند، أنداء

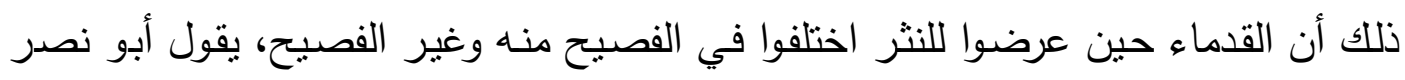

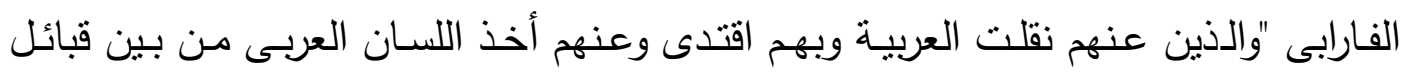

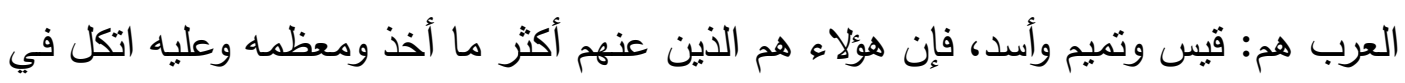

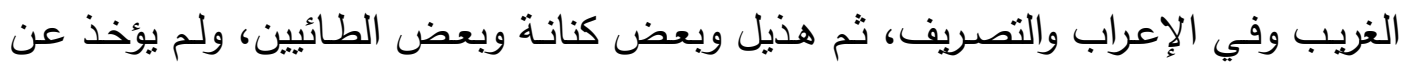

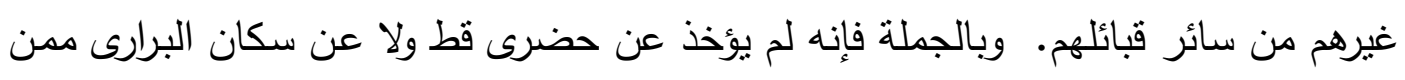

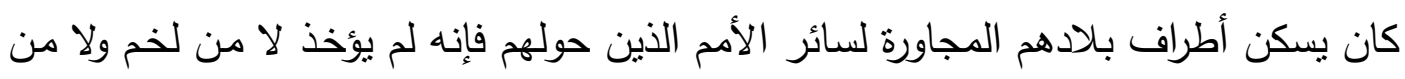
جذام لمجاورتهم أهل مصر والقبط ولا من قضاعة وغسان وإياد لمجاورتهم أهل الثنام وأكثرهم

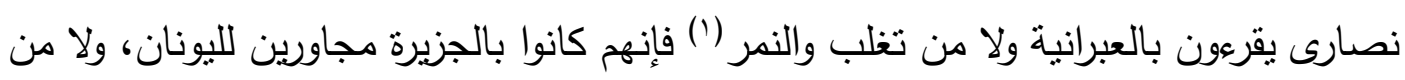
بكر لمجاورتهم للقبط والفرس، ولا من عبد قيس وأزد عمان، لأنهم كانوا بالبحرين مخالطين

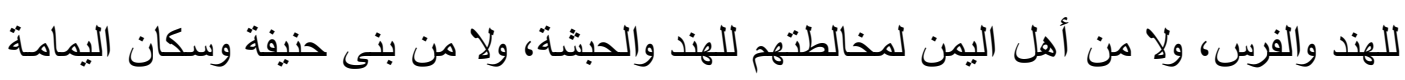

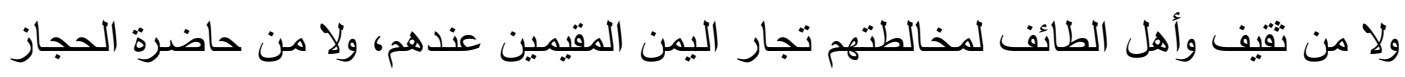

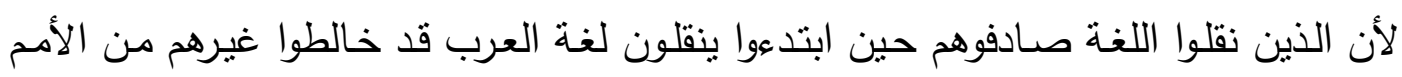

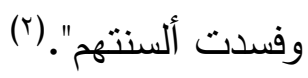
ومن النص السابق يتضـح أن اللغويين قد وضعوا شروطا جائرة حتى يقبلوا مادة النثر فكان

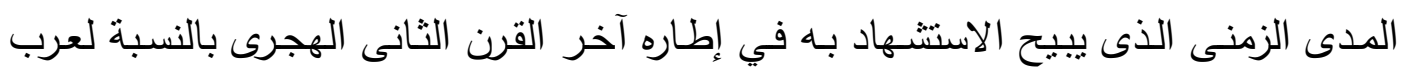

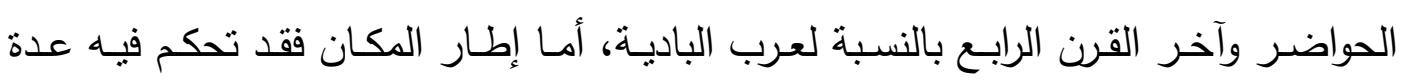

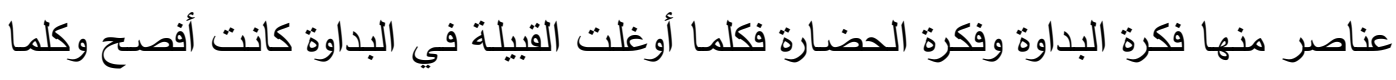
كانت متحضرة أو قريبة من حباة الحضارة كلما انتقص ذلك من فصاحتها وبالتالى تجنبوا

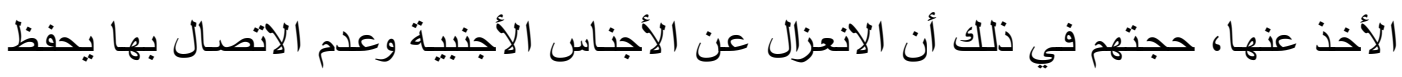

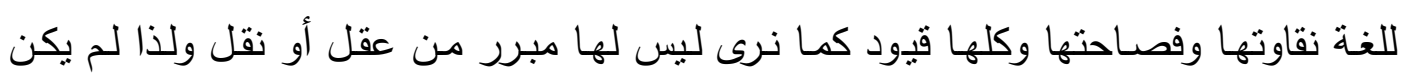

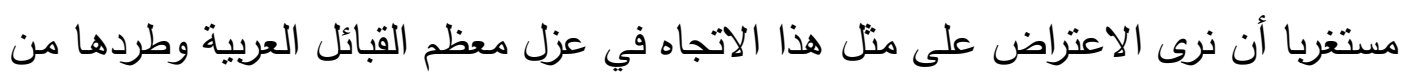

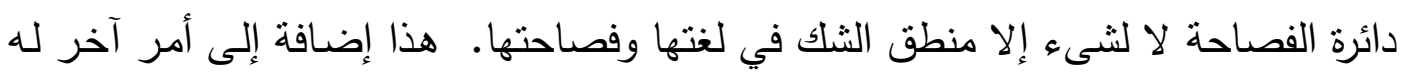

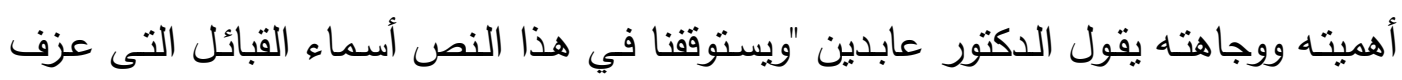
العلماء عن لهجتها واستبعدوها من دائرة الفصحى فإن كثيرا من القبائل التى ذكرها اسماعيل

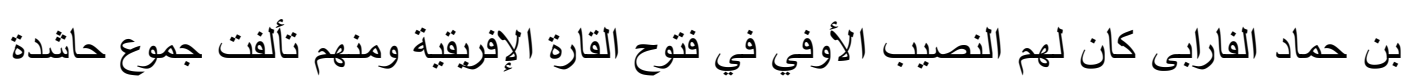


من جيوش الفتح ومنهم - أيضا - انتقلت في أعقاب الفتوح أفواج كثيرة حملوا معهم لهجاتهم الخاصة إلى مهاجرهم في أرض وادى النيل وبلاد المغرب وغيرها.

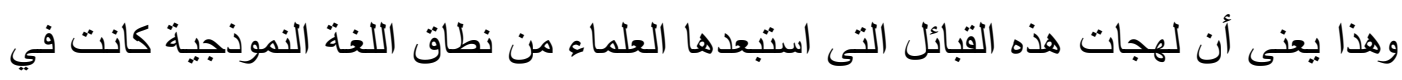

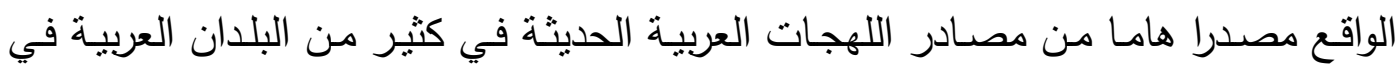
إفريقية كالمغرب ومصر والسودان ولا شك أن طائفة من سمات تلك اللهجات القديمة لا تزال

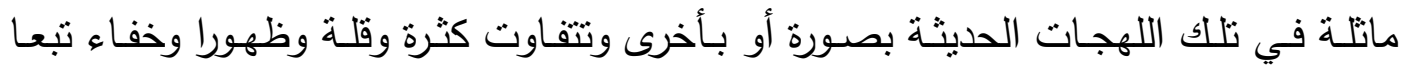
لاختلاف البيئات والمؤثرات ونسب التداخل والامتزاج التى نألفت منها على مر الزمن كل

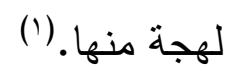

وهذا الرأى الذى قدمه الباحث هنا يشير إلى أن اللهجات العربية الحديثة لها جذورها العربية

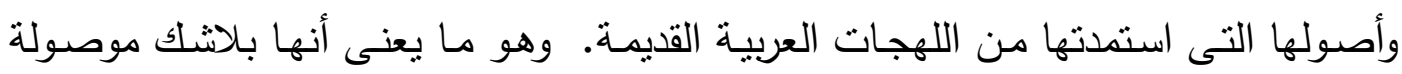

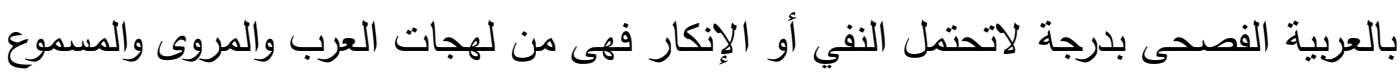

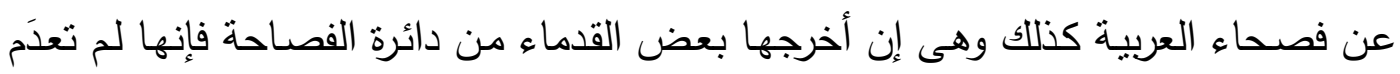

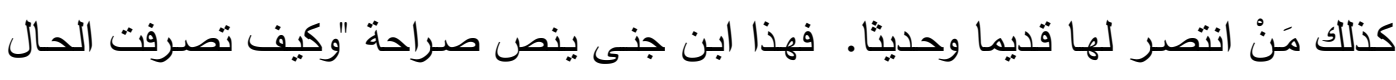

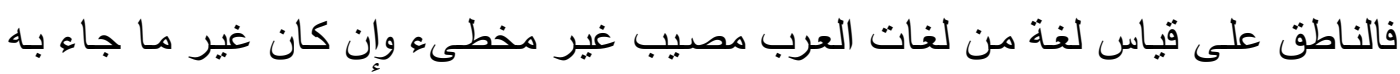

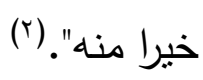
وفي مزهر السيوطى جاء قوله "وقد يلهج العرب الفصحاء بالكلمة الثـاذة عن القياس البعيدة

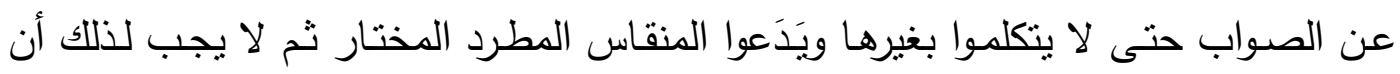

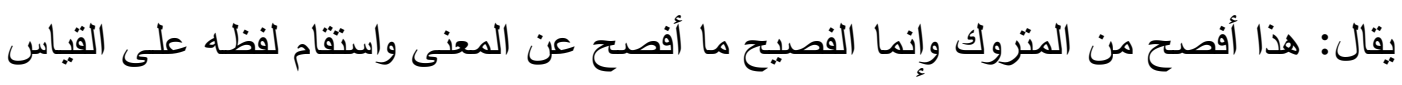

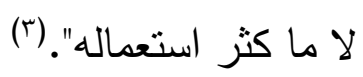

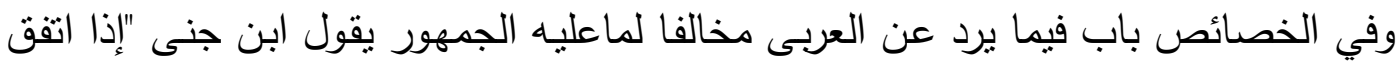

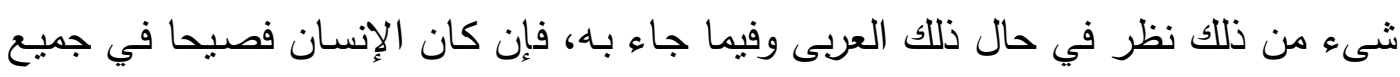

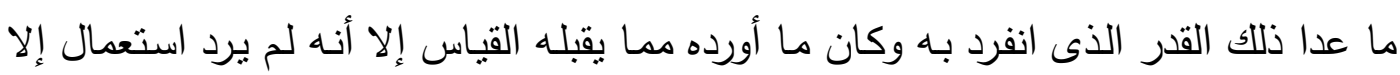

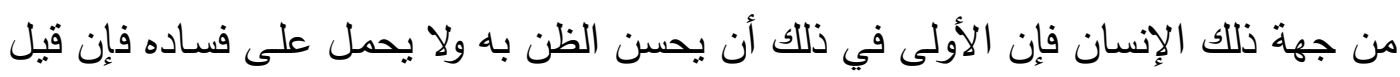

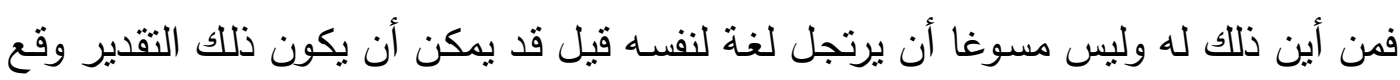

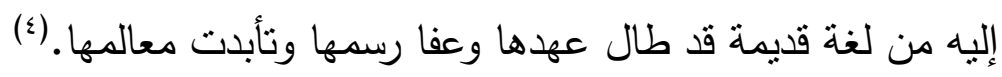

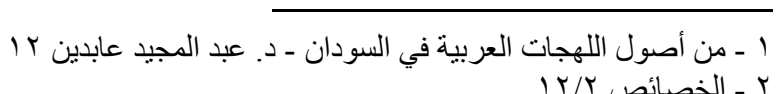

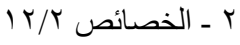

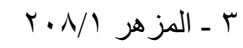

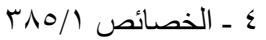


ويضيف "فإذا كان الأمر كذلك لم نقطع على الفصيح يُسمع منه ما يخالف الجمهور بالخطأ

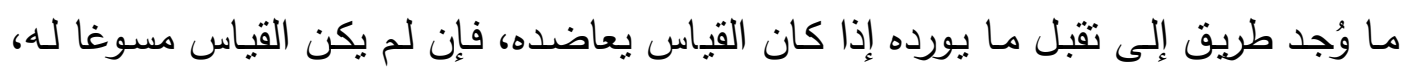

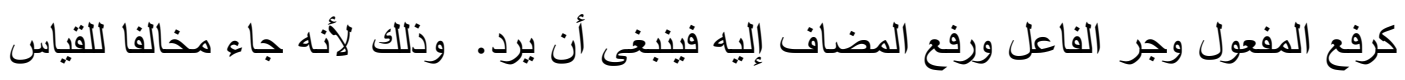

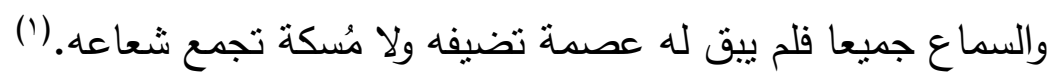

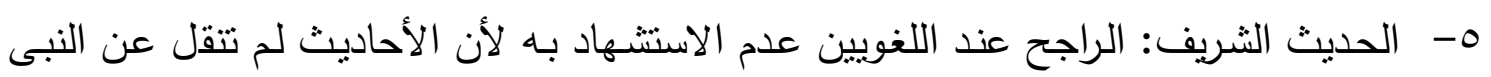
كما سمعت بل رويت بالمعنى فربما تجرى القصة الواحدة زمانه صلى الله عليه وسلم فلا تقال

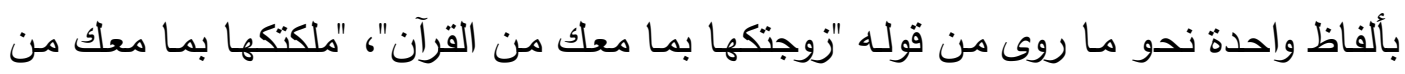

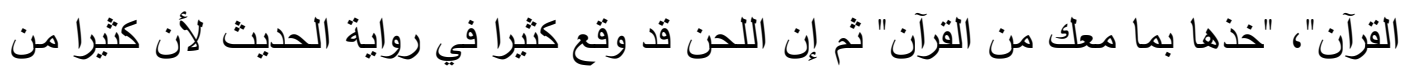

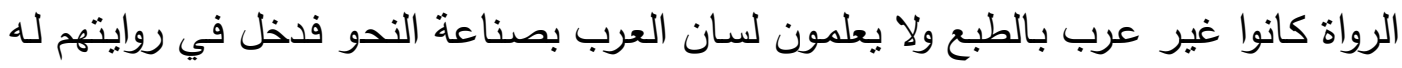

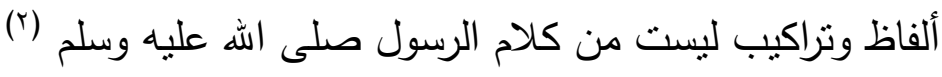
ونحن وإن كنّا نتقق مع القدماء في أن الحديث النبوى قد وقع اللحن كثيرا في روايته وأنه أو أو اله

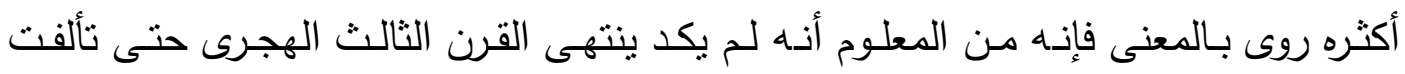

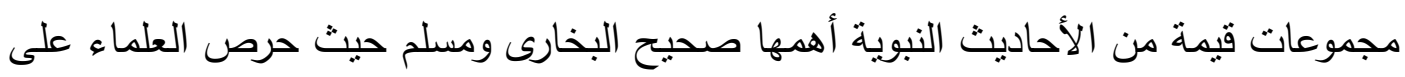

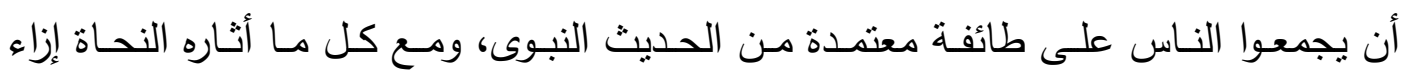

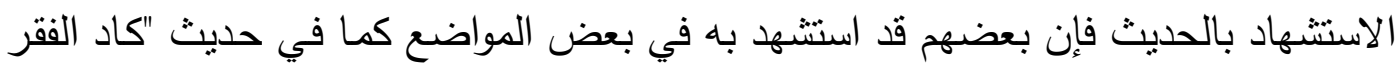

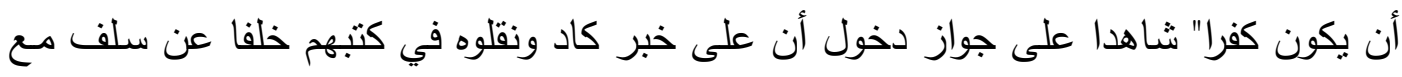

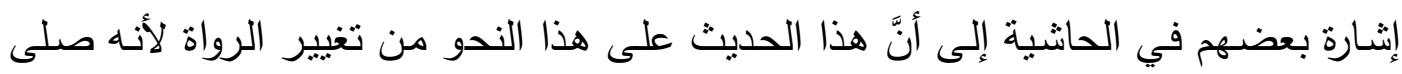
الله عليه وسلم أفصح من نطق بالضـاد. "وما كان أغناهم عن هذا الاضطراب والتتاقض لو أنهم أجازوا الاستشهاد بالأحاديث المعتمدة

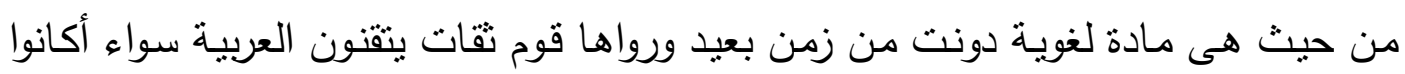

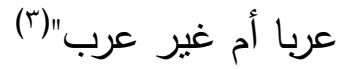
צ- القياس اللغوى: القياس هو حمل معلوم على معلوم في إثبات حكم له أو نفيه عنه بأمر جامع

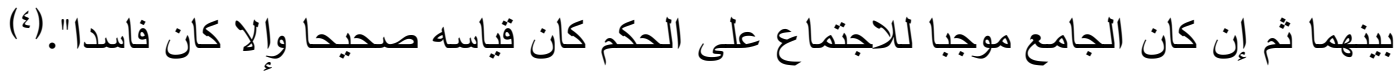

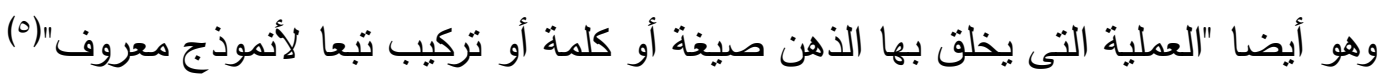


ويعمد المتكلم كلما دعت الحاجة إلى قياس أمور جديدة على ما في حافظته من أمور قديمة،

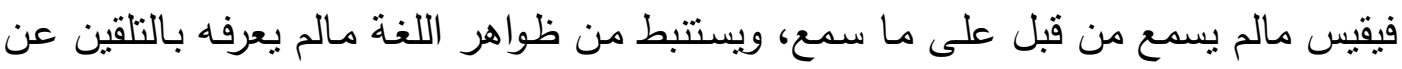
طريق ما عرفه بالتلقين وهو في كل هذا لا يهدف إلا إلى التعبير عما يدور بخلده كما يعبر

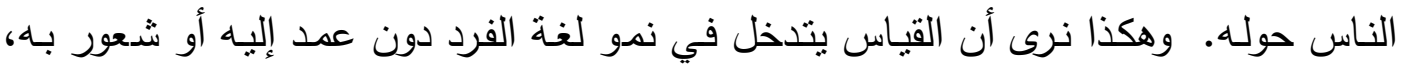
فعملية القياس مستمرة في كل لغة وفي كل عصر من عصوره بل يقوم بها كل فرد من أفراد

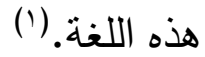

ورغم أهمية القياس لكل لغة بما له من دور في نموها وتطورها فإنه لم بسلم من الخـلاف

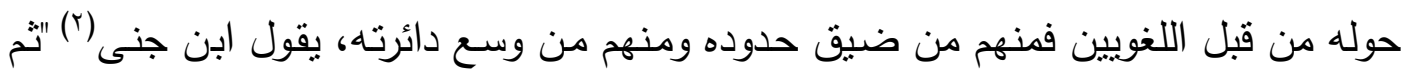
اعلم من بعد أن الكلام في الاطراد والثذذوذ على أربعة أضرب:

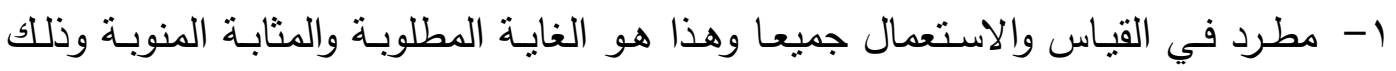

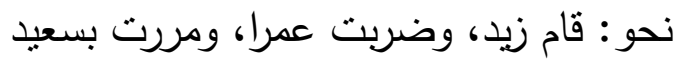

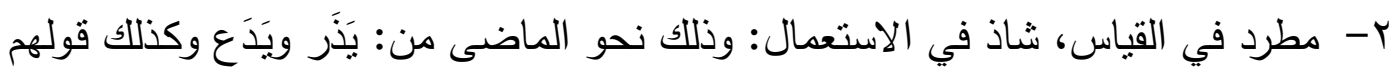

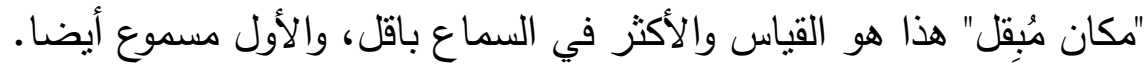

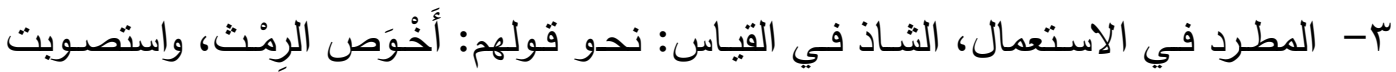

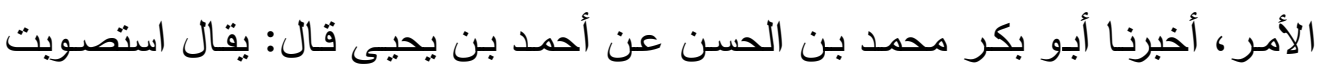

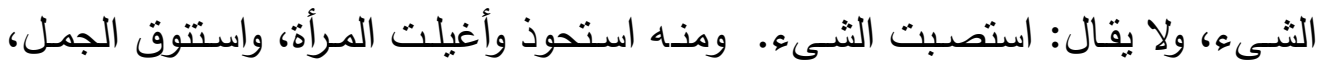

$$
\text { واستتيست الثاة. }
$$

ع - والرابع الثـاذ في القياس والاستعمال جميعا: وهو كتتميم مفعول، فيما عينه واو، ندو

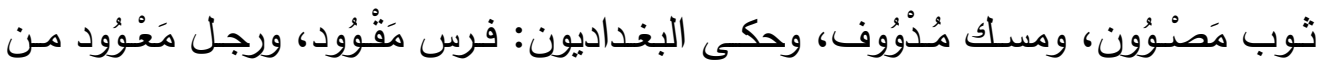
مرضده، وكل ذلك شاذ في القياس والاستعمال، فلا يسوغ القياس عليه ولا رد غيره إليه.

$$
\text { وفي كلام ابن جنى السباق ما يستحق المراجعة. }
$$

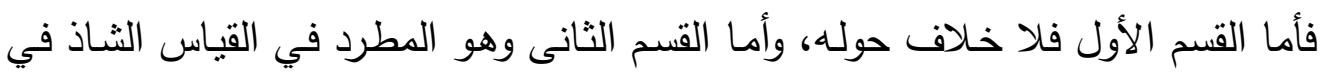

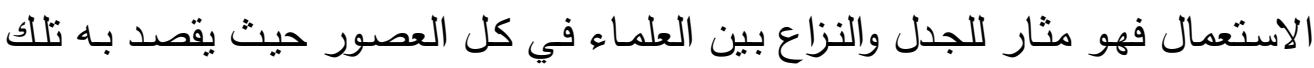

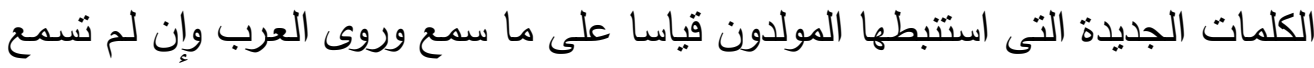
عن العرب ولم نرو عنهم، وهو ما يؤيده ما ذهب إليه ابن جنى في قوله "باب في جواز لهاز

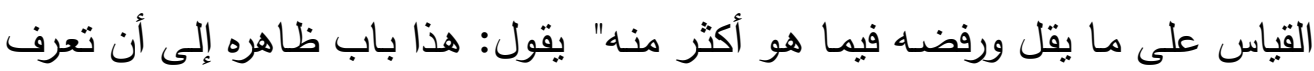


صورته ظاهر التناقض إلا أنه مع تأمله صحيح وذلك أن يقل الثىء وهو قياس ويكون

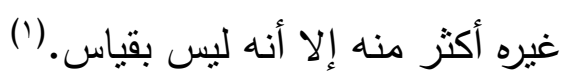

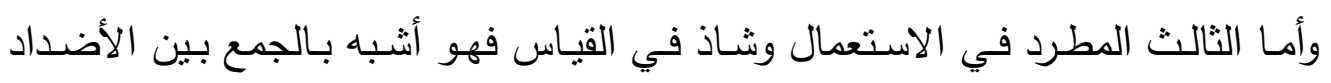

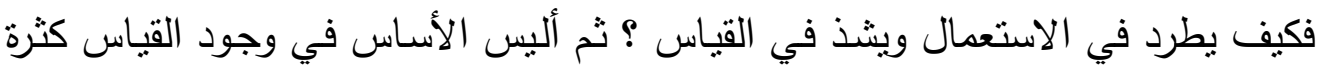

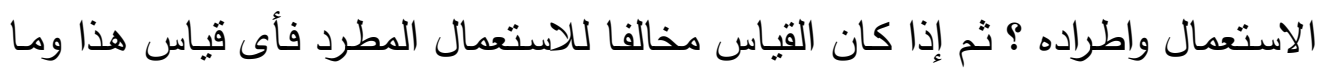

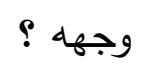

وأما الرابع فعجيب أن يأتى به ابن جنى هنا فهو قد فقد أسباب وجوده ناهيك عن قبوله

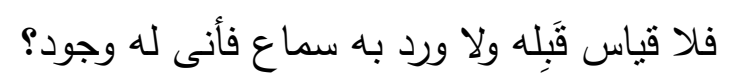

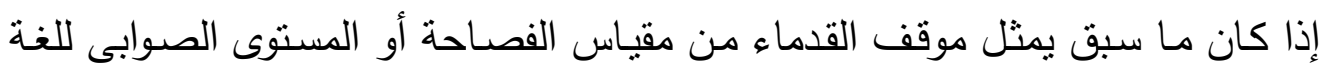

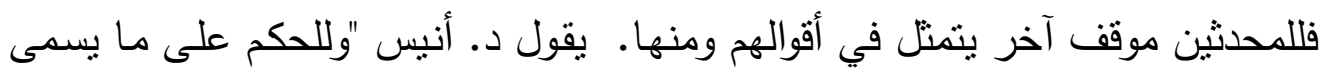

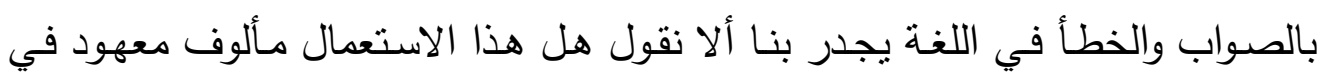

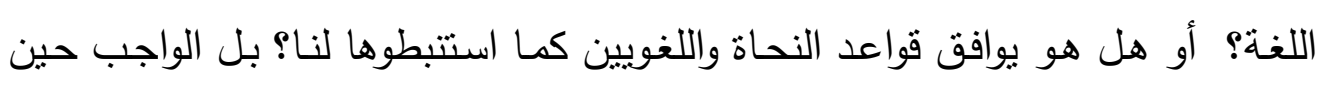
نسمع قولا ونريد الحكم عليه أن نتساءل هل استخرج المتكلم مثل هذا القول من حافظته

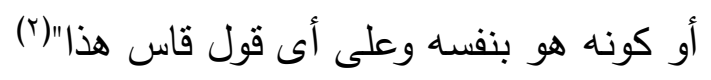

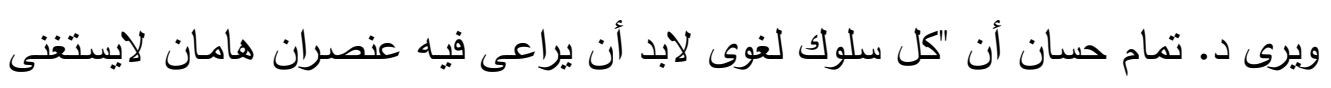
عنهما: 1- عنصر الوضوح: الذى يسد الحاجة اللغوية أو المعنى الوظيفي.

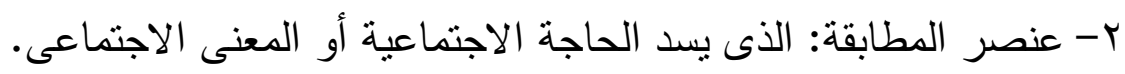

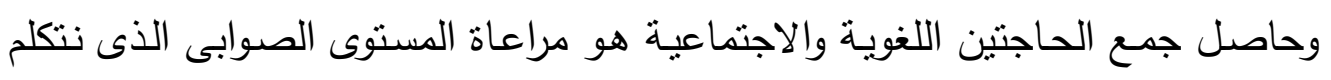

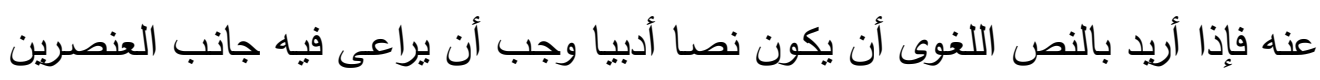

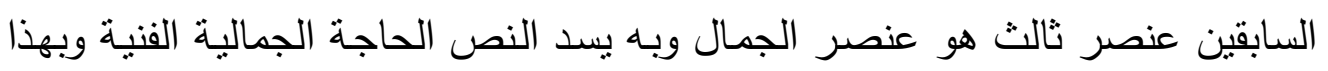

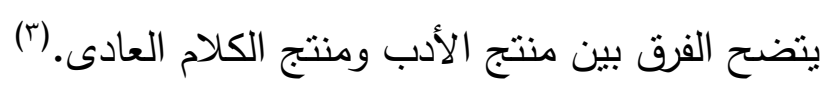

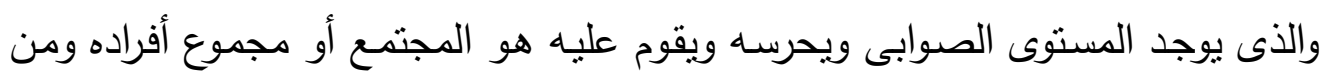

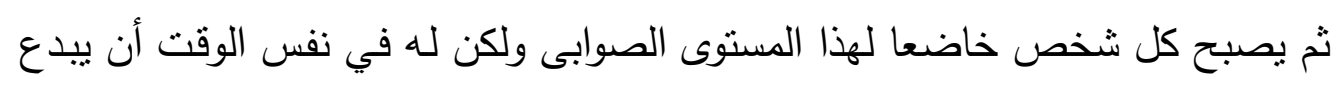

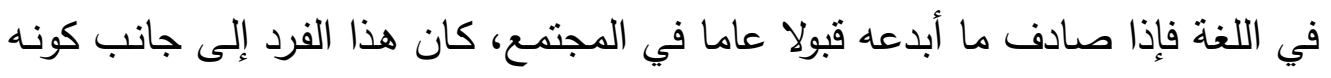

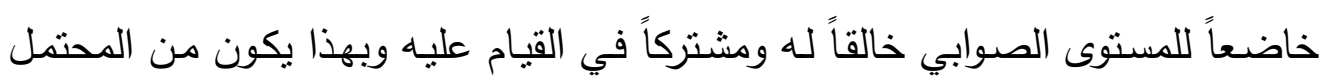


بالنسـبة للفـرد أن يكـون مـؤثرا أو متــأثرا بالنسـبـة للمسـتوى الصــوابى بحسـب الـدور

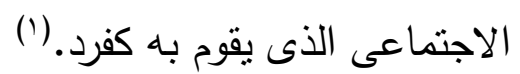

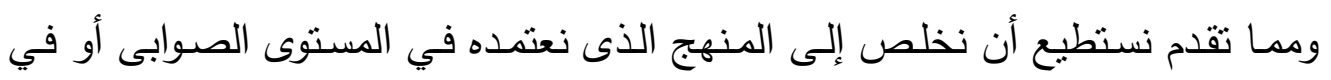

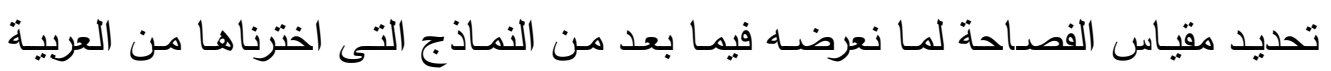

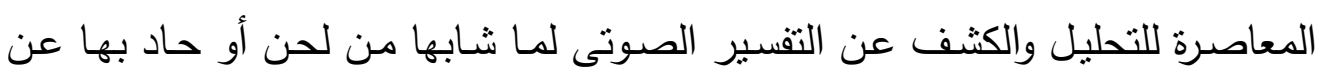
الفصاحة ويتلخص هذا المنهج في الآتى: - قبول كل ما وافق قياس العربية. - قبول كل ما وافق لهجة من اللهجات العربية القديمة. - قبول كل ما وافق رواية أو سماعا عن العرب.

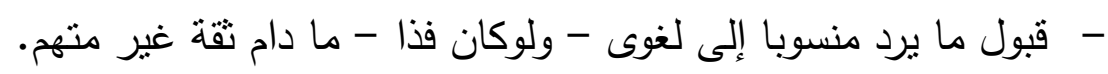
- قبول كل ما يمكن تخريجه على وجه من وجوه العربية قياسا أو سماعا.

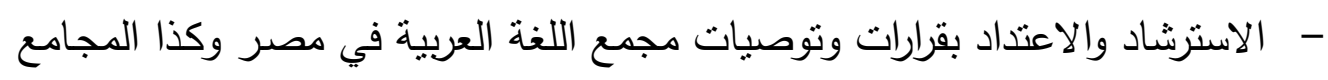
اللغوية الأخرى في البلدان العربية.

- الأخذ بما براه اللغويون المحدثون من عناصر التطور اللغوى وتتمية اللغة. - الترخص في الأخذ ببعض التعبيرات الثنائعة أو الأسـاليب المستحدثنة التى كـان

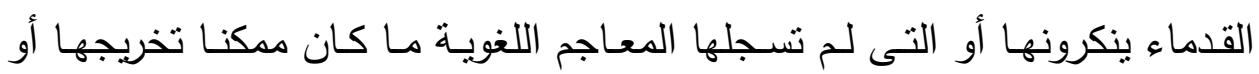

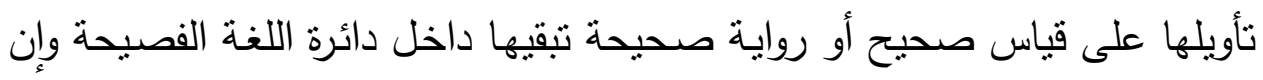
لم تكن الأفصح. - رفض كل ما جاء خارجا عن القياس أو السماع أو كليهما ولا يمكن رده إلى دائرة اللغة العربية على أى وجه كان.

والآن وبعد أن قدمنا فيمـا سـق معنى اللحن المقصـود الذي نستخدمه في هذا

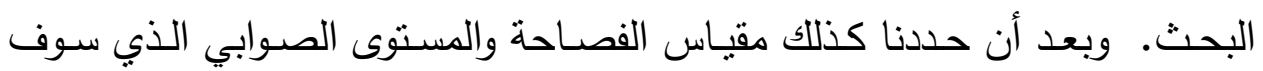
نلتزمـه فيه، نبدأ في تتـاول بعض النماذج من العربية المعاصرة التي أخضـعناها

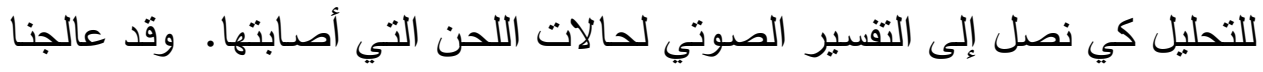
هذه الحالات تحت ثلاثة عناوين أساسية هي على الترنيب: الإبدال - الممانلـة

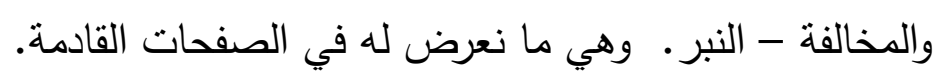


من اللظواهر اللغوية التى حظيت بعناية القدماء والمحثثين على السواء وقوع التبادل بين الأصوات اللغويـة وهو تطور طبيعى في أصوات كل اللغات وتتجلى مظـاهر عنايـة القدماء بـه في كثرة المؤلفات فيه سواء أكانت مؤلفات مستقلة للغوبين أو في أبواب عقدوها في مصنفاتهات الفهم المختلفة لهذه

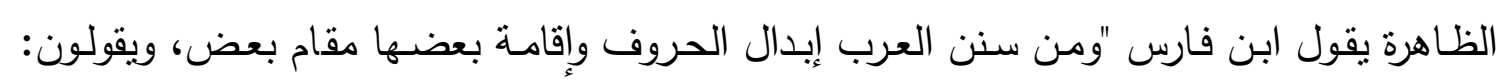

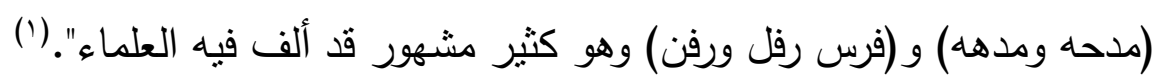

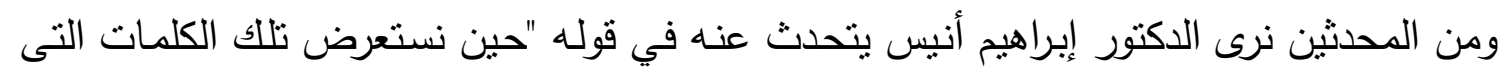

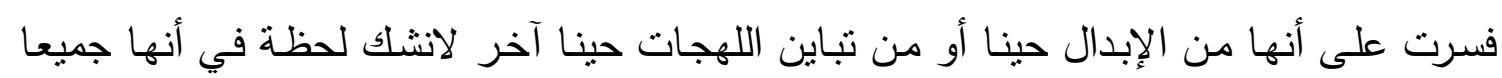

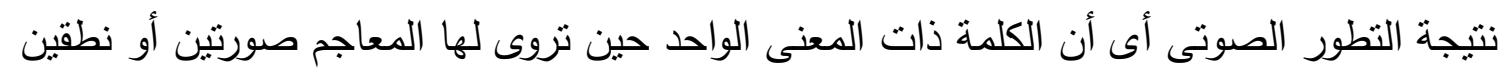

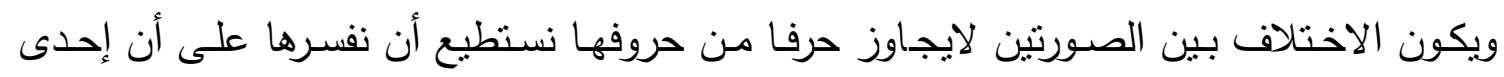

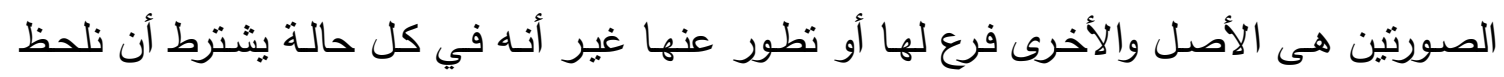

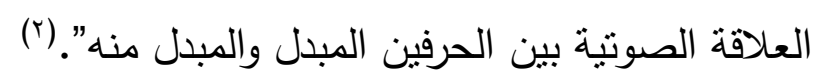
الإبدال اللغوى إذن ليس إلا نتيجة للتطور الصوتى والمعول في مسوغات الإبدال إنما يعتمد أساسـا

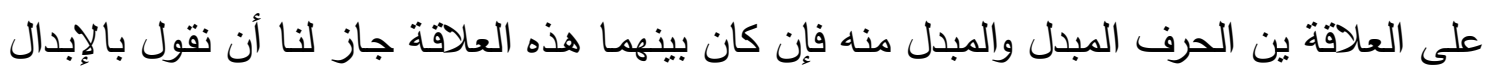
وإن انتقت هذه العلاقة امتتع القول بالإبدال. وفيمـا يلِى نعرض لبعض صـور الإبدال في العربيـة المعاصـرة لنرى مدى ارتباط هذه الحالات

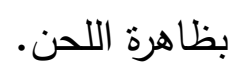

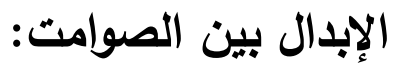

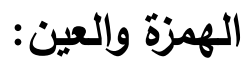

يقولون: فَقَعْت عين الرجل، وهو مفقوع العين، والصواب: فقأت عينه، وهو مفقوء العين، يقول

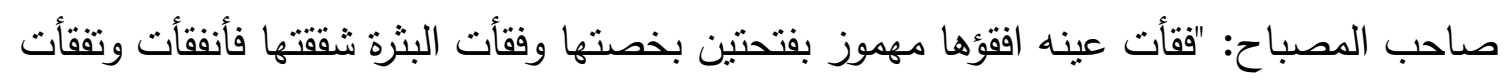

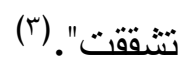

الهمزة = حرف حنجرى شديد لا هو بالمجهور ولا بالمهوس. العين = حرف حلقى رخو مجهور مرقق.(£ 
والعلاقة الصوتية بين الصوتين واضحة حيث نقارب مخرج الحرفين واختلفا صفة وهذا ما يعرف

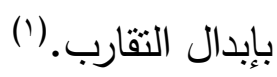

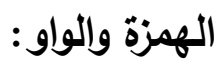

- يقولون: وازيته: أى حاذيته. والأفصح آزيته (ז). لأنه من الإزاء تقول جلست بإزائه، ولا نقول بوزائه.

يقول صاحب المصباح: الإزاء: منل كتاب هو الحِذاء وهو (بإزائه) أى مُحَاذيه (r).

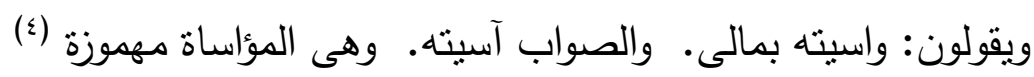

وفى الوسيط: (آسى) بينهما يؤاسى، ويواسى، مؤاساة، ومواساة: سَوَّى: و (آسى) فلانى النا بمالده:

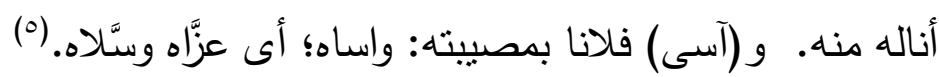

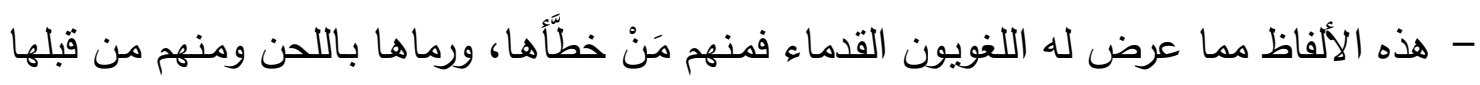

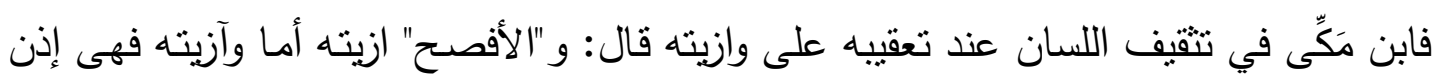

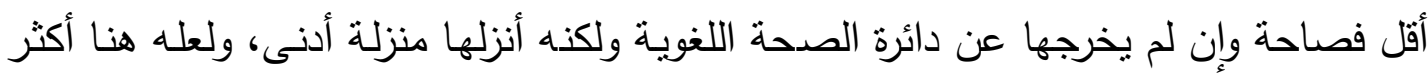

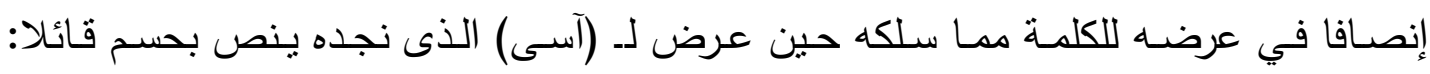

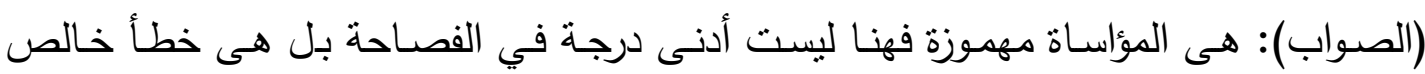

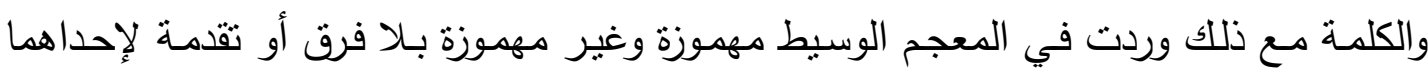

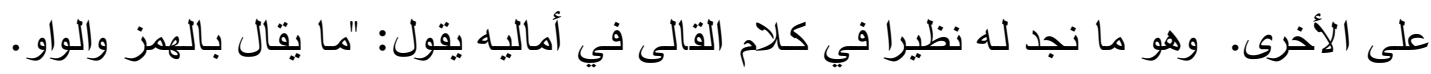

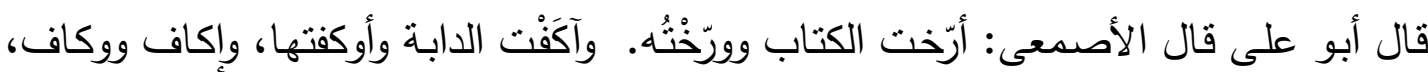

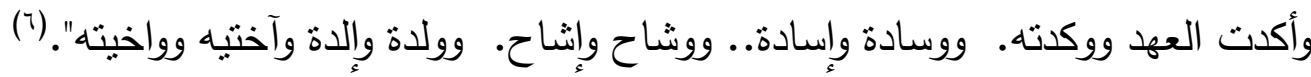

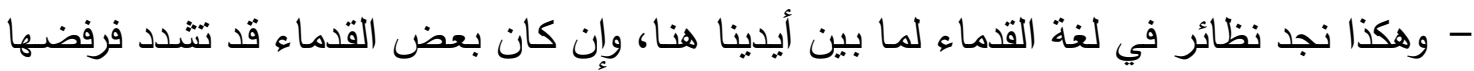

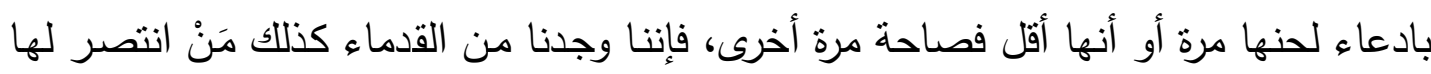

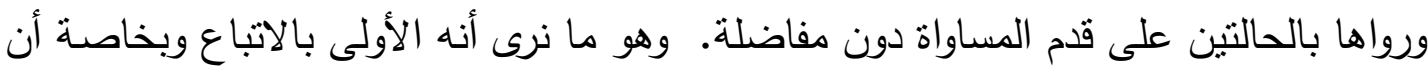
المعاجم اللغوية انتصرت لهذه الروئية وروت الكلمة بالحالتين المهوزة والمجردة منها.

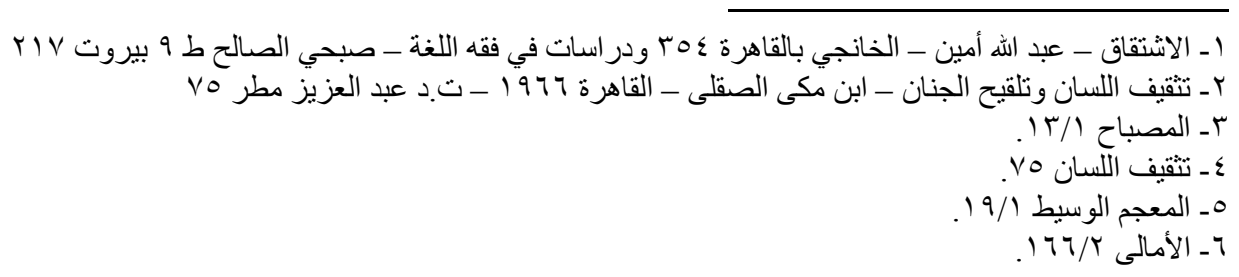




\section{الهمزة والياء :}

ورد عدد من الكلمات في العربية المعاصرة غير مهوزة والأصل فيها الهمز على ما سوف نراه

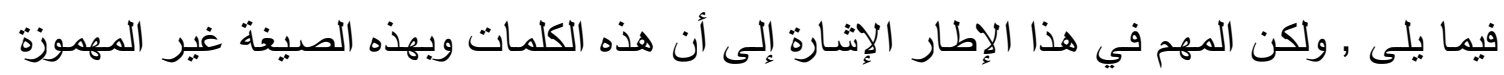

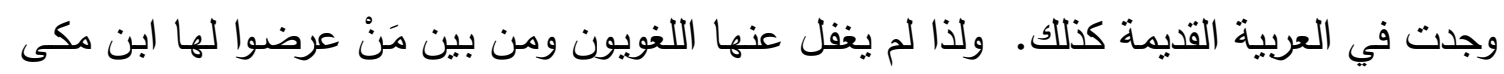

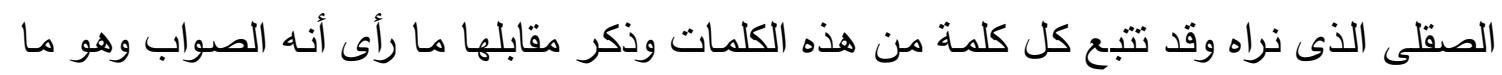

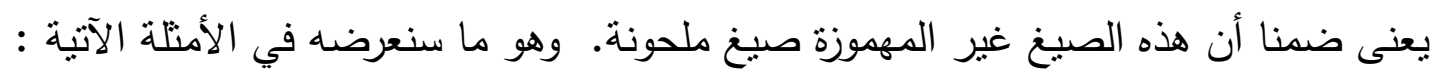

$$
\begin{aligned}
& \text { يقولون: - قَرِيت الكتاب } \\
& \text { ظهرت مساوِيه } \\
& \text { سََلَيت السمن } \\
& \text { مََّيت الإناء } \\
& \text { خَبيت الثَئ مَّيَ } \\
& \text { هَدَيْت من قَلقى }
\end{aligned}
$$

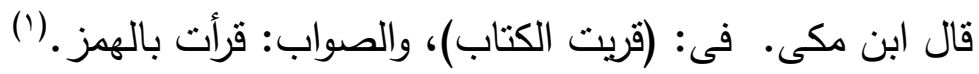

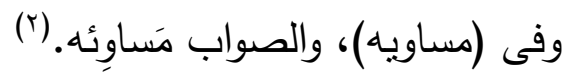

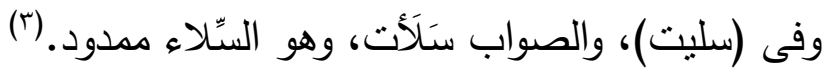

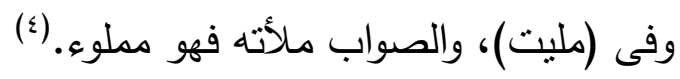

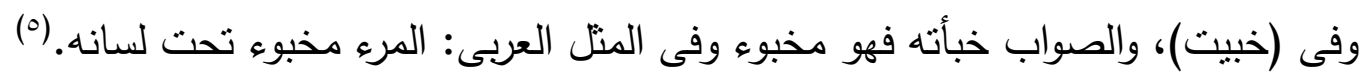

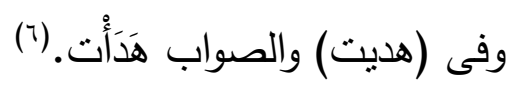

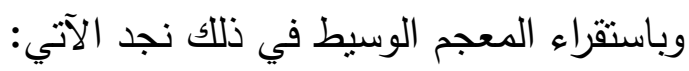

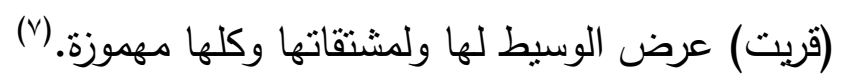

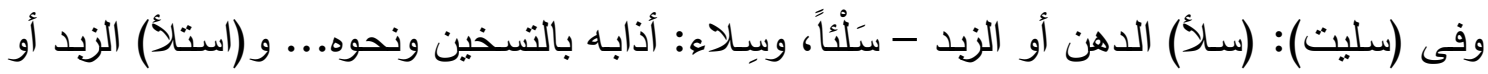

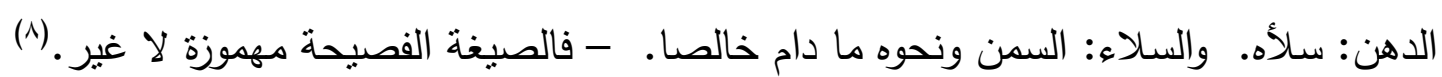

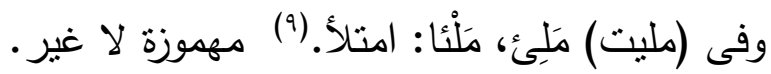




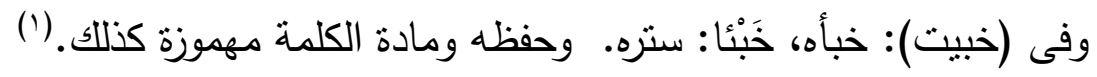

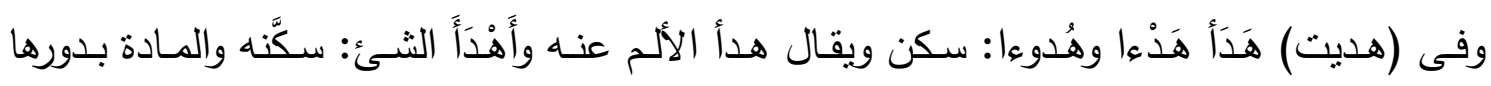
مهموزة) وفى (ه) أما (مساويه) فقد قدم الوسيط مادتها على النحو الآتى :

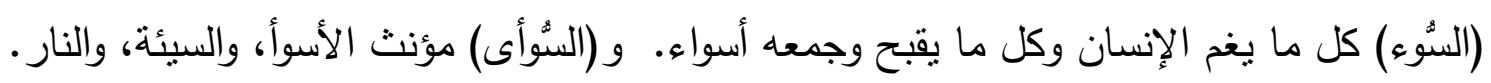

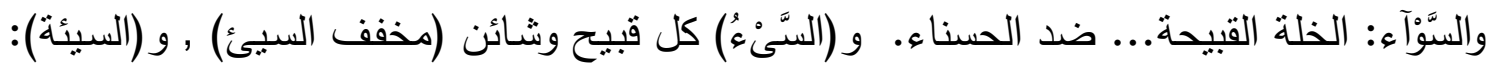
الصغير من الذنوب، والعيب والنقص والخطيئة و (المساءة): نقيض المسرة.

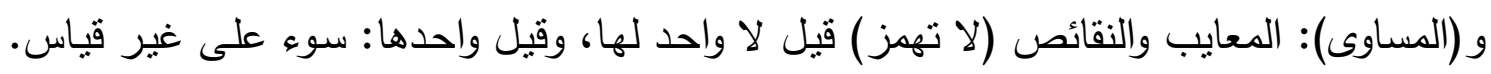

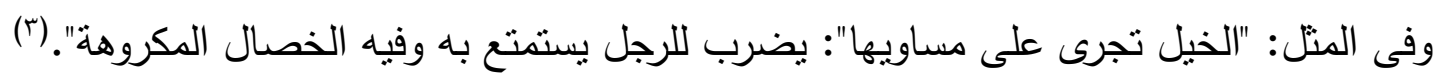

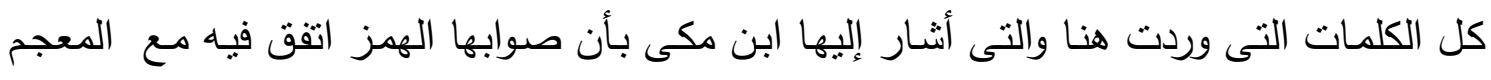

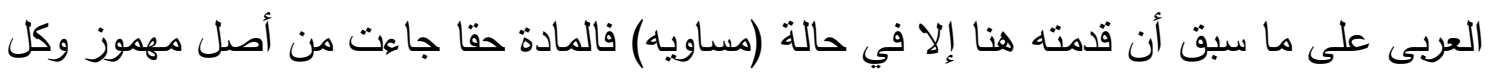

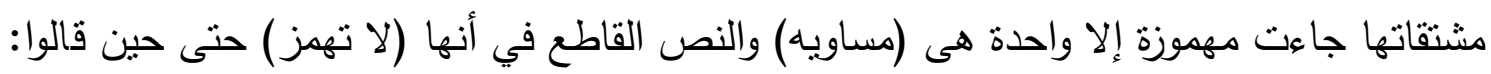
وقيل واحدها: (سوء) على غير قياس ولعل هذا ما أغرى ابن مكى ودفعه إلى القول: والصواب: مساوئه بالهمز . فالكلمة على حالها هكذا (مساويه) فصيحة صحيحة والمدهش أنها وحدها بين مشتقات واستعمالات

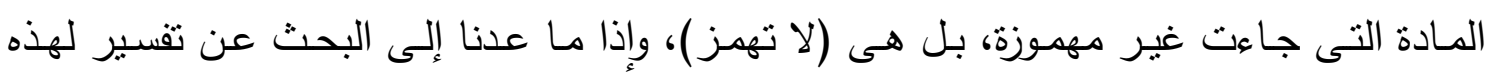
الظاهزة نقول. صوت الهمزة = صوت حنجرى شديد لا هو بالمجهور ولا بالمهموس. صوت الباء = صوت غارى منوسط لين (๕). وواضح التباعد بين الصوتين مخرجا وصفة فلا علاقة صوتية إذن تجيز مثل هذا الإبدال ولكننا

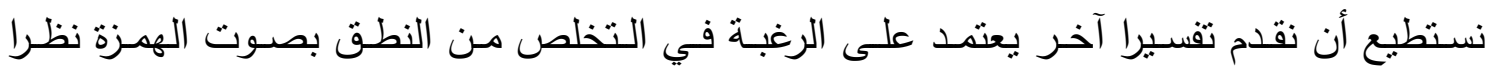

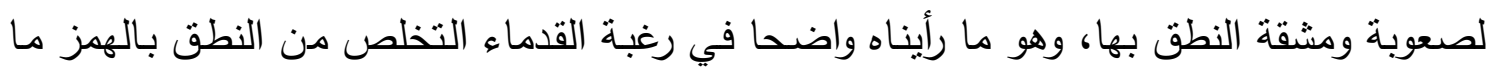
تيسير لهم ذلك أو أتيح لهم ولذلك تعددت وسائلهم في ذلك مثل نطقها مسهلة كما في قولهم مثنا (آمل، آريت) في (أمل، أرأيت)، أو حذقها كما في قولهم (تيها، وألاك) بدلا من (تيهاء، وأولئك)

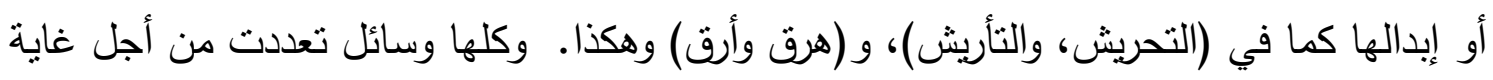

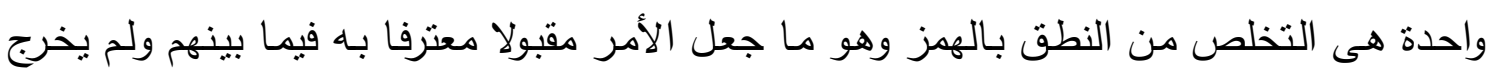


مثل هذه الحالات من دائرة الفصاحة أو الصحة اللغوية. ولعل فيما يرويه ابن جنى صدد عرضها لهذه الظاهرة ما يؤكد صحة ما ذهبنا إليه هنا. يقول ابن جنى في (باب في حذف الهمز وإبداله): قد جاء هذا الموضع في النثر والنظم جميعا وكلاهما غير مقيس عليه، إلا عند الضرورة فإن قلت: فهلا فست على مانى ما جاء منه في النثر ، لأنه

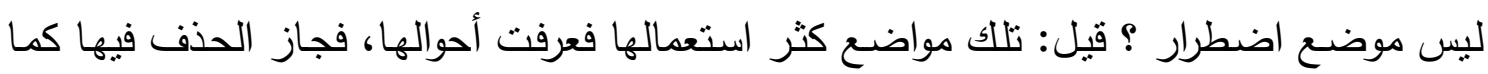
حذفت لم يك، ولم بيل، ولا أدر في النثر، لكثرة الاستعمال ولم يقس عليها غيرها (').

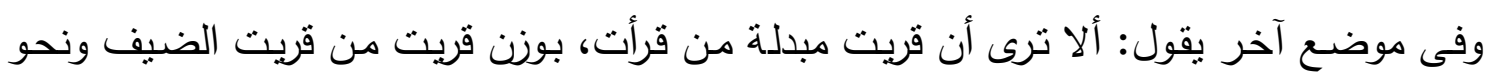
ذللك (r)

ويقول: "لقى أبو زيد سييويه فقال له: سمعت العرب تقول: قريت، وتوضيت، فقال له سيويه: كيف

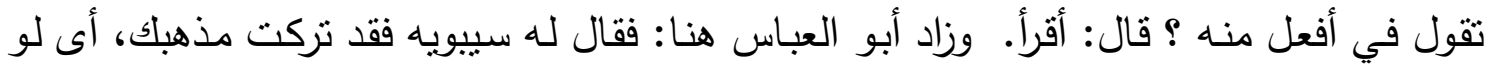

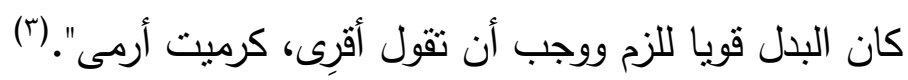

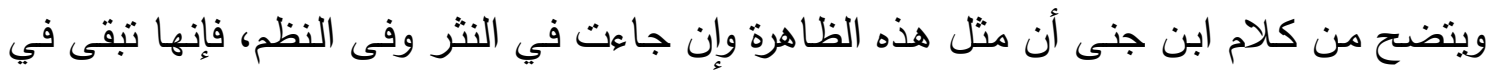
نطاق السماع الذى نقبله بحدوده تلك دون القياس عليه، إلا عند الضرورة وحتى في هذا هذا التحديد

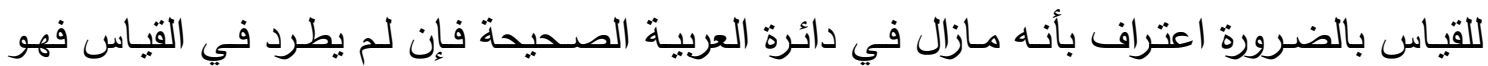

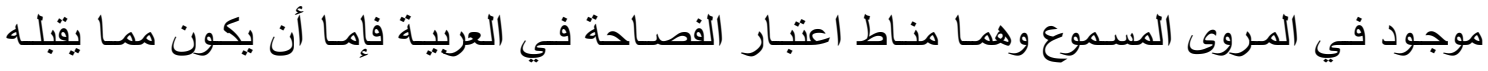

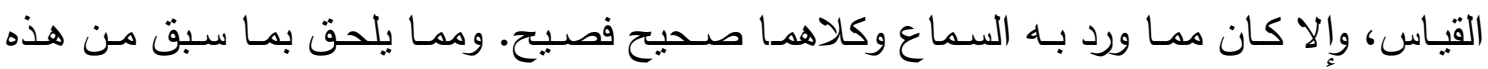

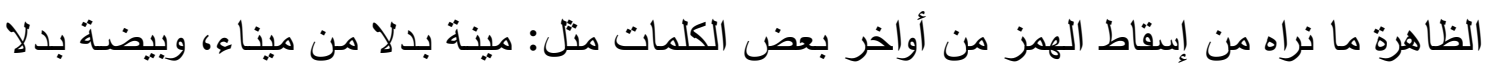

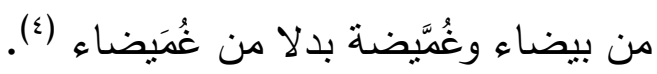

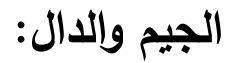

ومما جاء من ذللك قولهم لِمَّا يُطحن من البُر وما شابهه غليظا: دشيش.(0) والصدواب جَثِيش بالجيم. وفى القاموس المحيط: والجَثِيشِ حنطة تطحن جليلا فتجعل في قدر

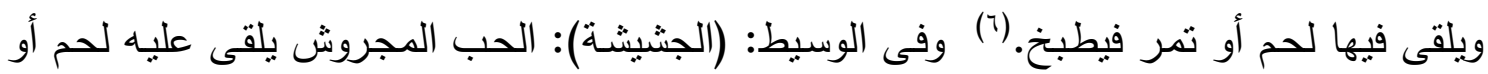

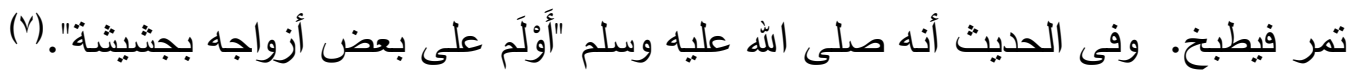




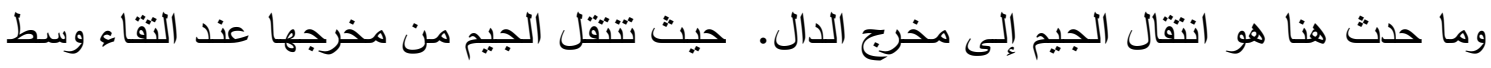

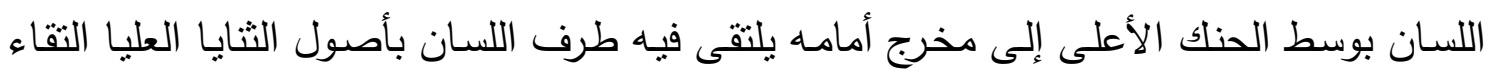

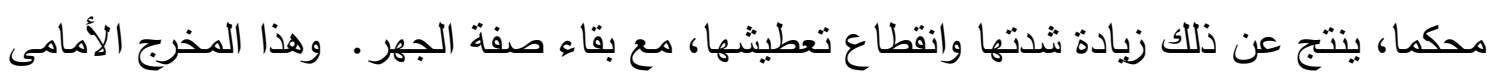

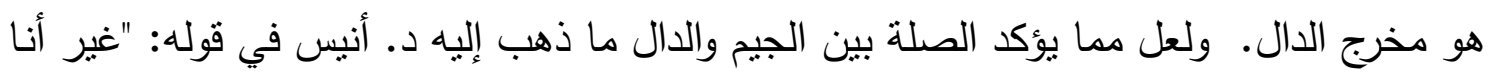

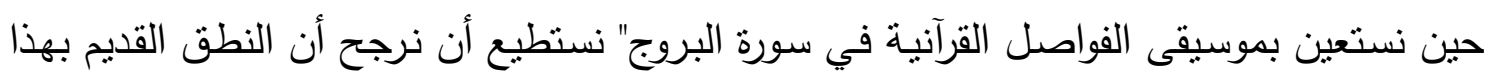

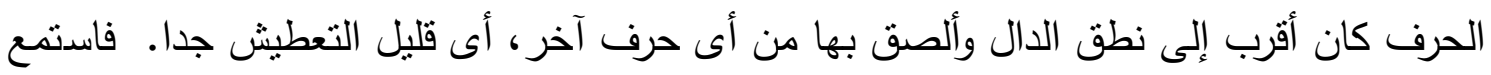

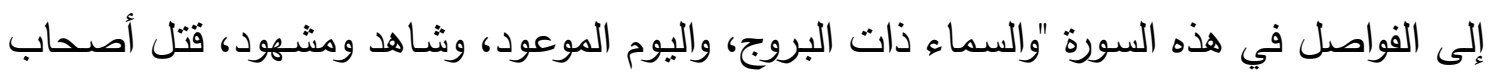

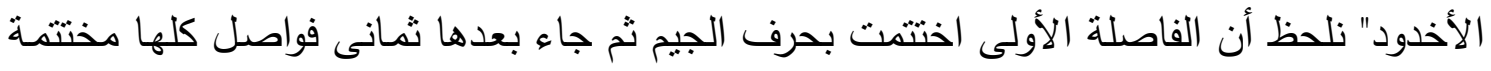

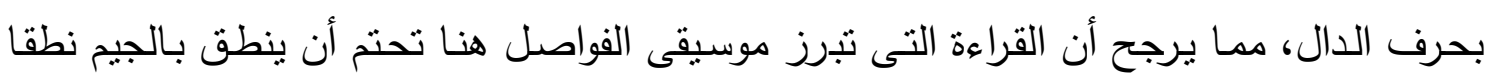

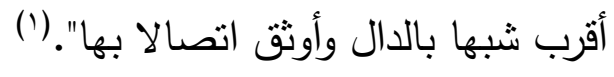

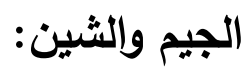

ومنه قولهم: انترَّت الماثية، والصواب: اجترت، وهو أن تجتر ما في بطنها (؟).

وفى الوسيط: اجتر البعير : أخرج جرَّنه. (َ)

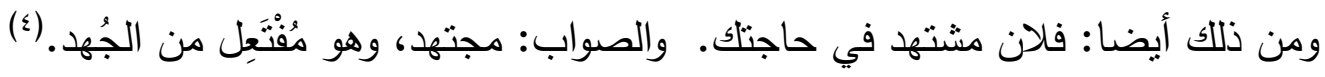
الجيم: صوت مجهور قليل الثندة غارى.

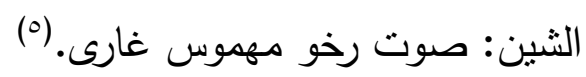
والعلاقة الصوتية بين الجيم والثشين واضحة والتبادل بينهما مقبول من الناحية الصوتية فالجيم

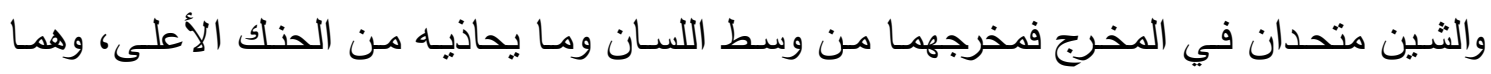

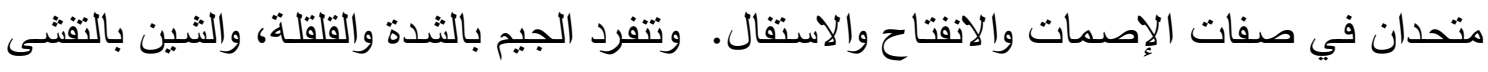
والهمس. (؟)

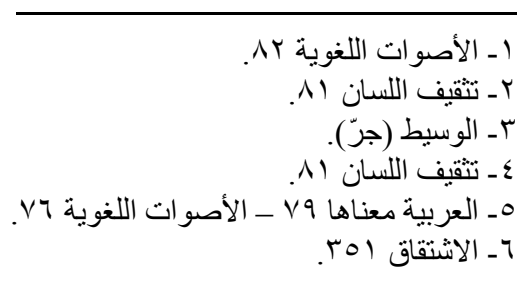


مما يتداول قولهم: غفير القوم - أو يعمل في غِفارة فلان، والصواب بالخاء يقال: خِفارة وخُفارة وخفرة.)

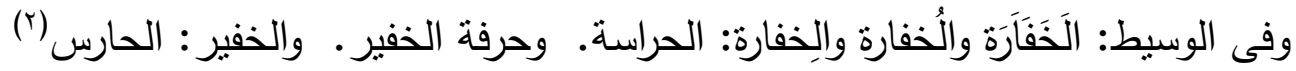

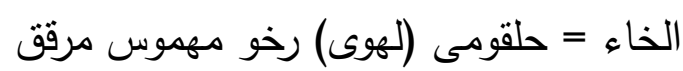

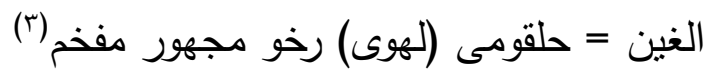
وقع التبادل بين صوتى الخاء والغين وهو من إبدال التجانس حيث تقاربا مخربا واختلفا صفة

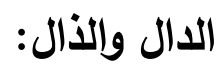

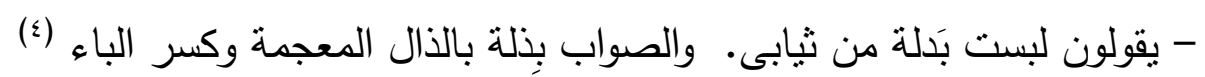

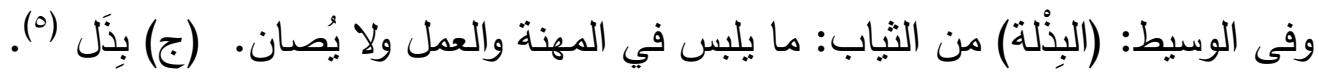

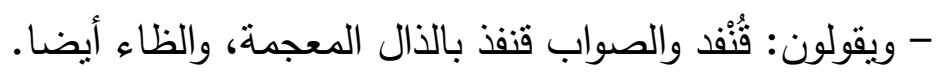

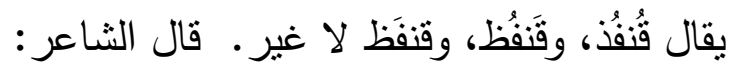

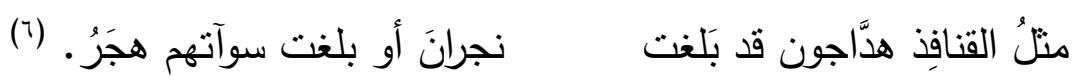
وفى الوسيط: القُنْفُ:ُ دوبية من الثدييات ذات شوك حاد. يلتف فيصير كالكرة، وبذلك يقى نفسه من خطر الاعتداء عليه و (ج) قنافذ (vان.

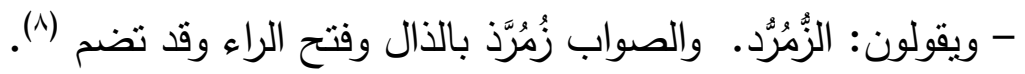
وفى الوسيط: الزُّمرُد: حجر كريم أخضر اللون، شديد الخضرة، شفاف، وأثدّده خضرة أجوده وأصفاه

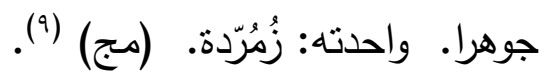

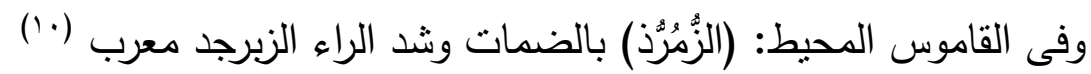

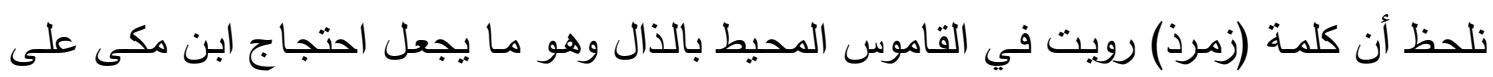

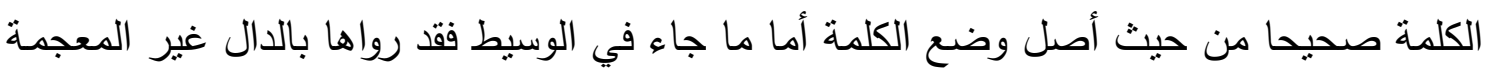

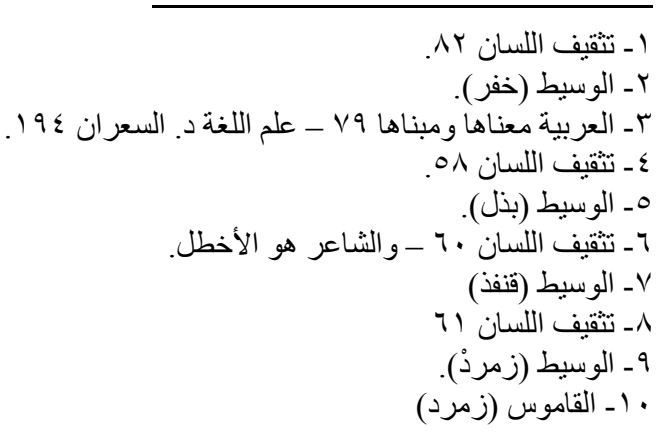


وذلك باعتبار أنها ممـا أقره المجمـع. وبالتالى لا يكون هناك مبرر للنظر إليها باعتبارهـا من الملحون أو غير الصحيح. أما العلاقة بين الدال والذال فتتمثل في الآتى : د = حرف أسنانى لثوى شديد مجهور مرقق.

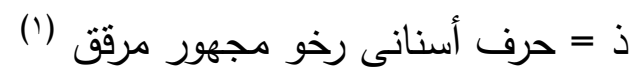

وهذا من إبدال التقارب حيث تقاربا مخرجا واختلفا صفة.

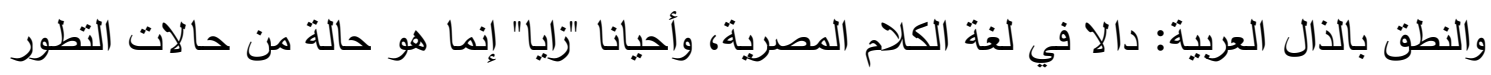

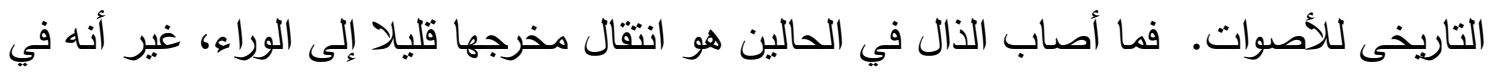

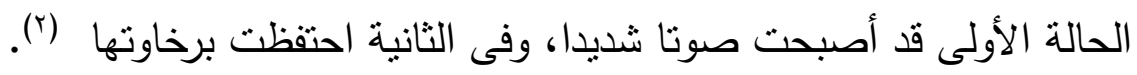

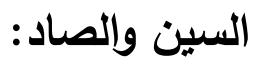

ألفاظ نطقت بالسين وأصلها الصاد. - يقولون: هذه فرسة فانتهزها، والصواب فرصة بالصاد.

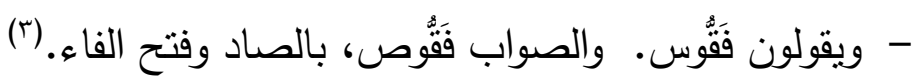

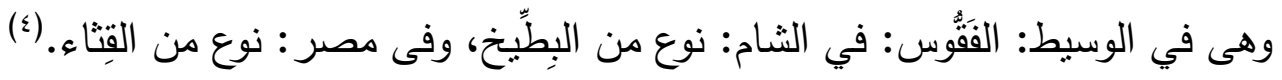

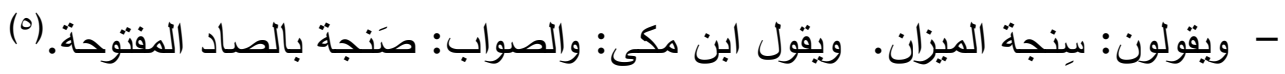
- وفى الوسيط: الصنجة: السنجة. (؟) - ويقولون فقست البيضـة. والصـواب: فقصت بلهن بالصـاد وفتح القاف في الماضـى وكسرها في

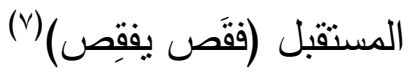

- وفى الوسبط: فقص: فقس (^) 
- يقولون: أصابه نِقَرص: والصواب: نِقِرِس (') - أخذنه قصرا والصواب: قسرا بالسين والقسر : القهر • - ويقولون للكتاب الكبير : صِفر • والصواب: سفر

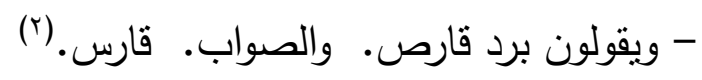

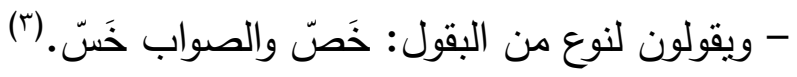

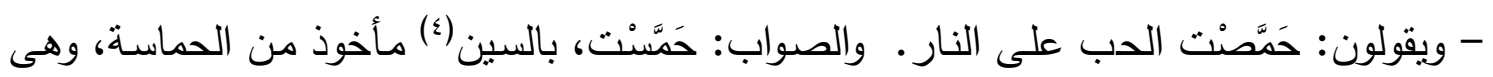
الثُدة، وإنما قيل لقريش "الحُمْس" لثُدنهم في دينهم. - وبقولون: صور المدينة والصواب: سور المدينة - ومما لا يفرقون فيه بين السين والصاد في لفظ ولا كتاب: سرة البطن وصرة الدراهم والصواب:

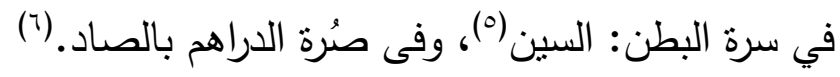
بداية وقبل أن نفصل القول في العلاقة الصوتية بين السين والصاد نلحظ هنا حالة من الاضطراب عند عرض هذه المفردات ففى (فقوس) ذهب ابن مكى إلى القول إنها خطأ والصـواب فقوص بالصاد بينما نراها في الوسيط بالسين وحده. وفى السنجة ذهب ابن مكى إلى أن صوابها صنجة بالصاد بينما في الوسيط سَّوى بينهما فقال الصنجة: السنجة. وأيضا اعترض أبن مكى على فقس بالسين وصوابها بالصاد أما الوسيط فذكر فقص: فقس. وبرد قارص خطأها ابن مكى. وصوبها

$$
\text { الزمخثرى في أساس البلاغة.(v) }
$$

فإذا ما تحولنا إلى ظاهرة الإبدال بين السين والصاد لننظر في العلاقة الصوتية بينهما اتضح أن هذه الظـاهرة ليسـت بالجديدة أو المستحدثة بـل هـى ظـاهرة قديمـة بؤكد ذلك اهتمـام القدماء بهـا

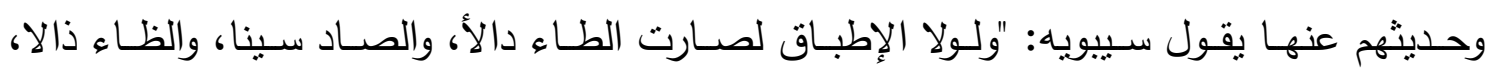
ولخرجت الضاد من الكلام، لأنه ليس شئ من موضعها غيرها".(^) وهو قول دقيق، فالسين: صوت أسنانى لثوى رخو مهموس مرقق. أما الصـاد فهى صدوت أسنانى لثوى رخو مهموس مفخم. فليس من فرق بينهما إلا إطباق الصاد دون السين.

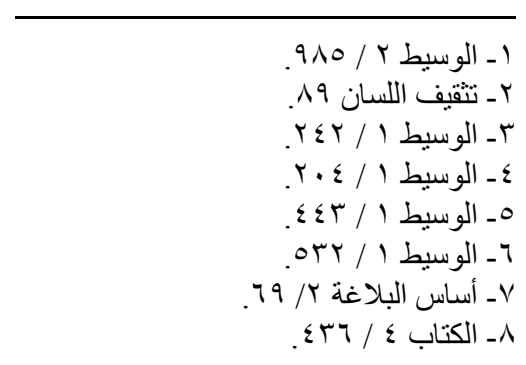


وفى خصائص ابن جنى نجد حديثه عن التقريب بين الأصوات من غير إدغام يقول: ومن ذلك أن تقع السين قبل الحرف المستعلى فتقرب منه بقلبها صـادا وذلك كقولهم في سُقت: صقتى، وفى التى السوق: الصوق، وفى سبقت: صبقت. (')

أما صاحب المزهر فقد أورد ما ذكره البطليوسى في كتاب الفرق بين الأحرف الخمسة:

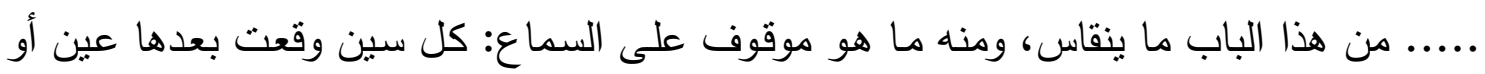

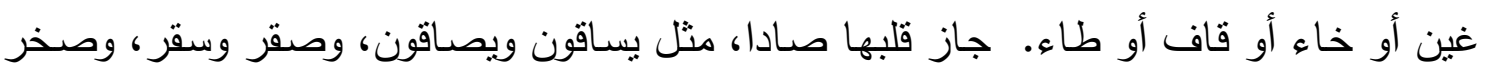

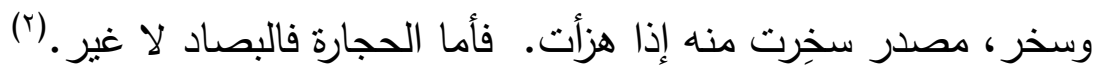
وأضاف: وشرط هذا الباب أن تكون السين متقدمة على هذه الحروف لا متأخرة بعدها وأن تكون

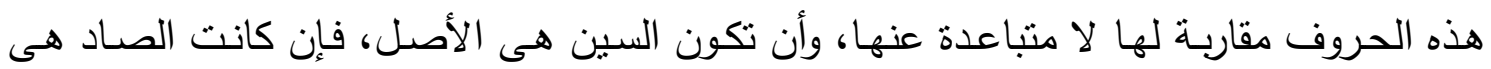

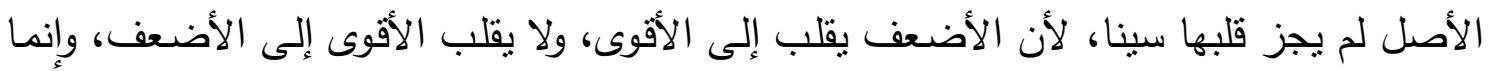

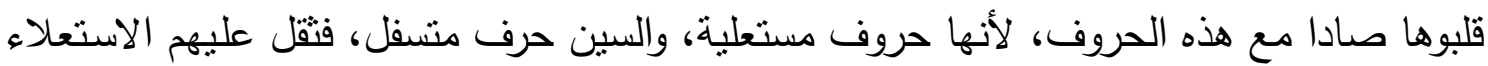

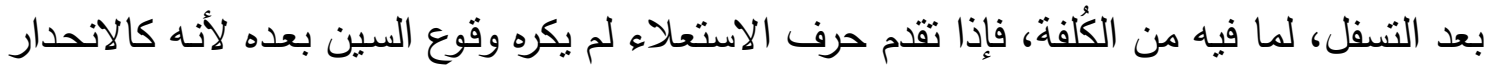

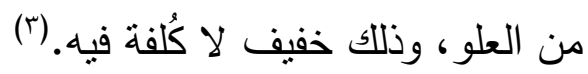
ومن هذا النص نعلم أن من الكلمات المبدلة هنا ما يرجع إلى السماع ومنها ما يعتمد على القياس

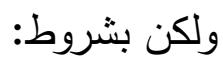
- أن تكون السين متقدمة على العين أو الغين أو الخاء أو القاف أو الطاء وحينئذ يجوز قلبها

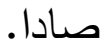
- أن تكون هذه الحروف مقاربة لها غير منباعدة عنها.

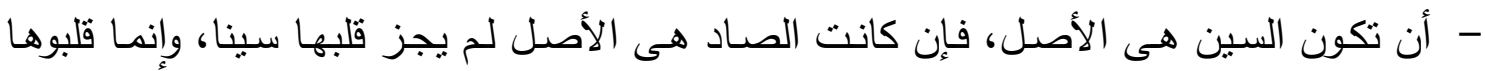
صادا مع هذه الحروف لأنها حروف مستعلية.

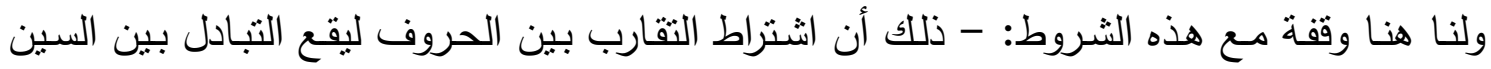
والصـاد يمكن الترخص فيـه حجتتا قول سييويه "وربما ضـارعوا بها وهى بعيدة نحو مصـادر ، والصراط، لأن الطاء كالدال، والمضسارعة هنا وإن بعدت الدال بمنزلة قولهم: صويق ومصساليق،

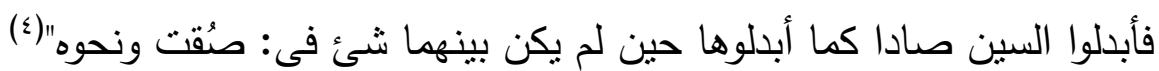

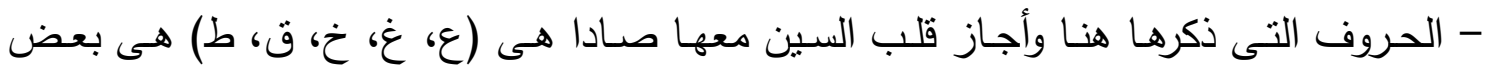

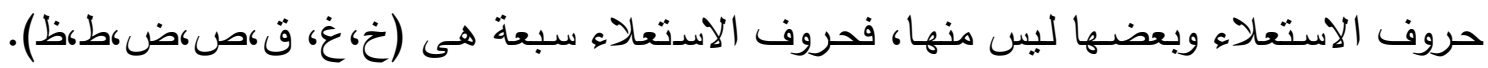




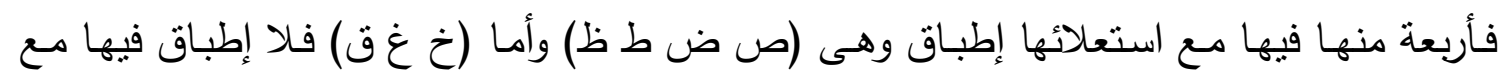

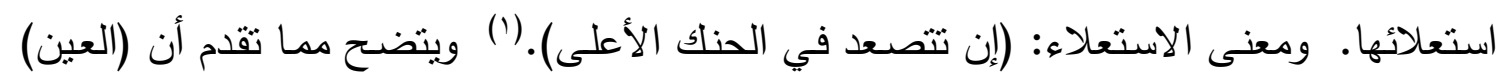
ليس من حروف الاستعلاء وبذلك يكون إدراجها هنا من قبيل الخطأ.

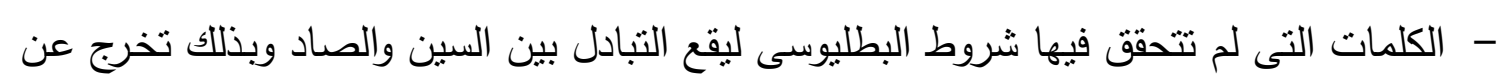

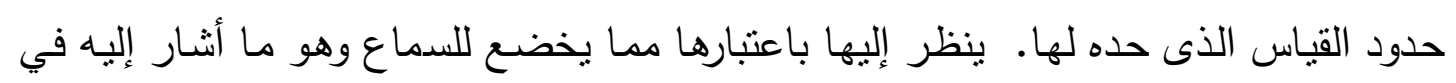
قوله: "ومنه ما هو موقوف على السماع". ومع ذللك تبقى العلاقة الصوتية بين الصوتين قائمة الصنة وواضحة فالسين هى الصاد دون إطباق.

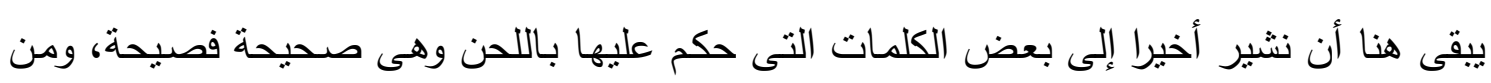
ثم وجب الانتباه إليها ومنها:- (برد قارص) التى اعترض علئ إنى اليها ابن مكى ورماها باللحن وصوابها

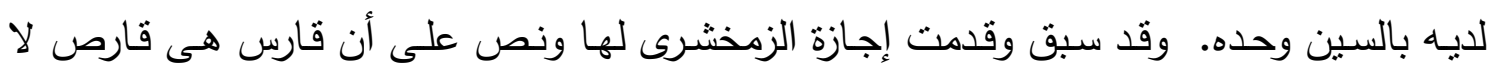

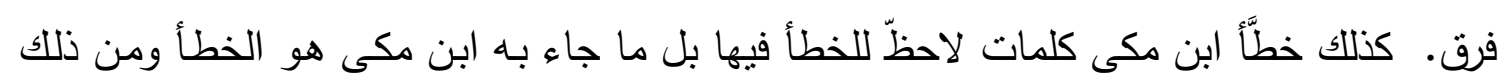

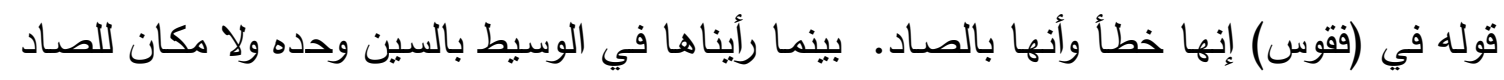

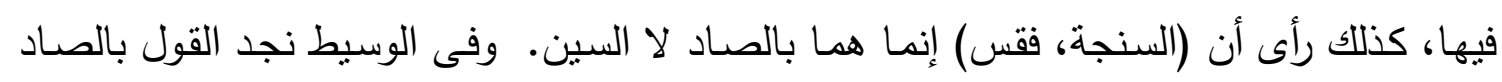

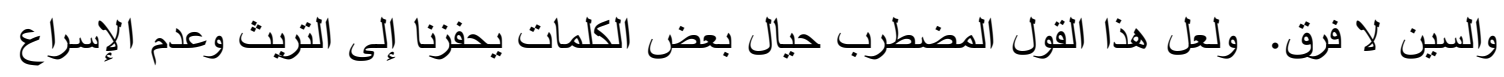

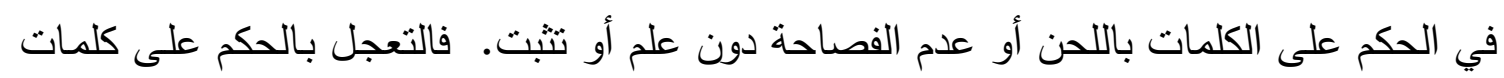

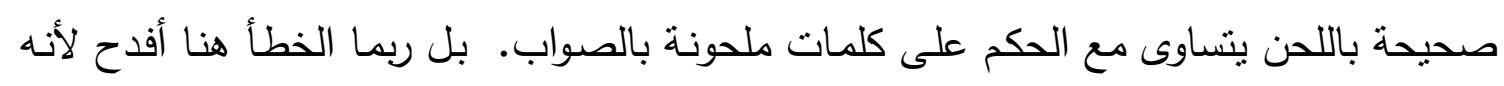

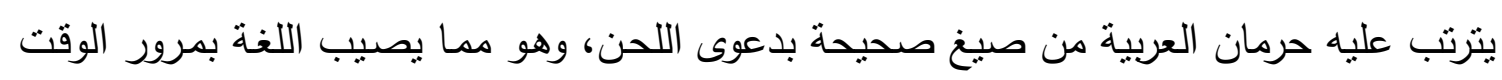

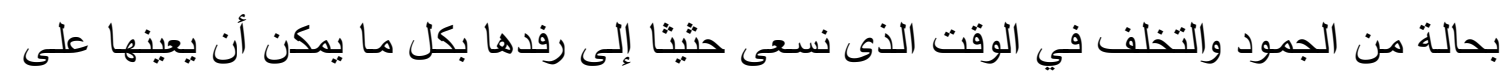

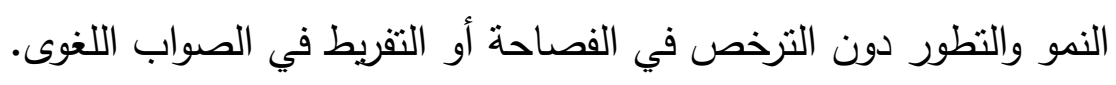

\section{العين والغين:}

- يقولون: نَعَق الغراب. والصـواب: نَغَقق؛ بـالغين معجمـة. نَغَق الغراب: صـاح فهو نـاغِقُ،

(r).

العين = حلقى رخو مرقق مجهور .

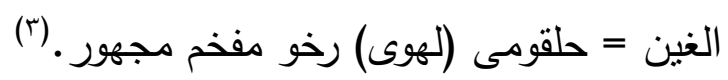

تقارب الحرفان مخرجا وصفة وهذا من إبدال الثقارب. (') 
الواو والياء:

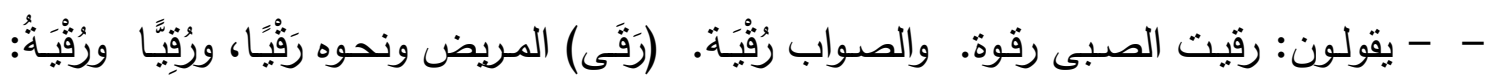

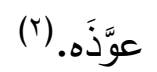

- ويقولون: مات مَوْتة سَوْه. و والصواب: مِينَة سوه.

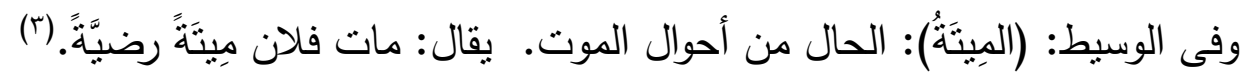

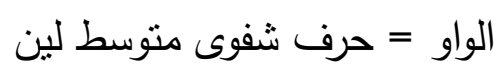

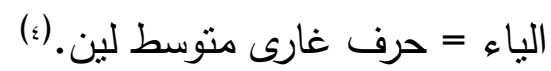

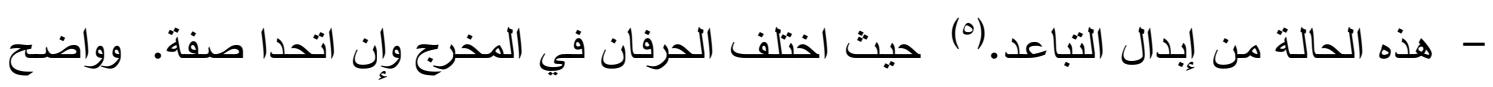
أن هذه من صور اللحن الواضحة التى ليس لها سند من قياس أو سماع. 


\section{المماثلة والمخالفة}

تتأثر الأصوات اللغوية فيما بينها تأثرا ينتج عنه حالة من التقارب في المخرج أو الصفة وهو ما يؤدى إلى تحقيق الانسجام الصوتى، وتوفير الجهد العضلى وتيسير عملية النطق وهو ما بطلق

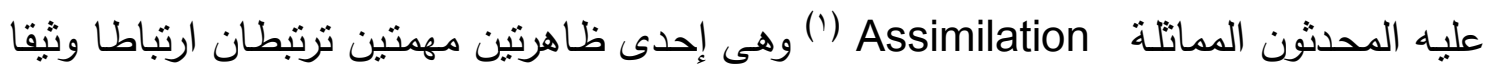
بعملية تجاور الأصوات اللغوية وتأثر بعضها ببعض. أما الظاهرة الأخرى فهى ما يطلق عليه الهيه

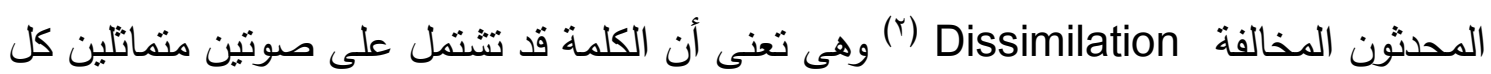
الممانلة ينقلب أحدها إلى صوت آخر لتتم المخالفة بين الصوتين المتماتلين.

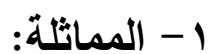

المماتلـة تقرب بين الأصوات المتجاورة في المخرج والصفة وقد يصل هذا التقريب بين الصوتين

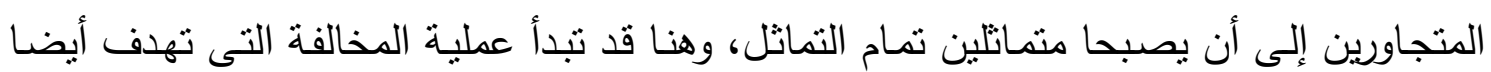

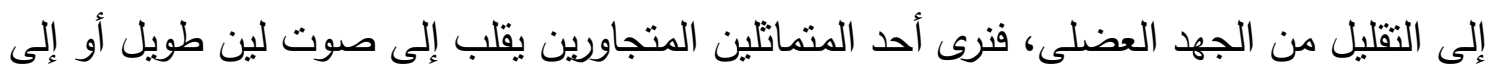

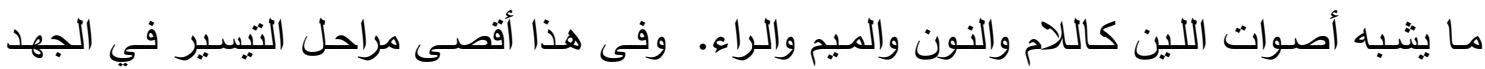

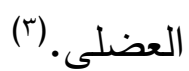
ولم يغفل القدماء عن هذه الظاهرة حيث أنثاروا إليها إثارات توضح إدراكهم لطبيعتها يقول سييويه

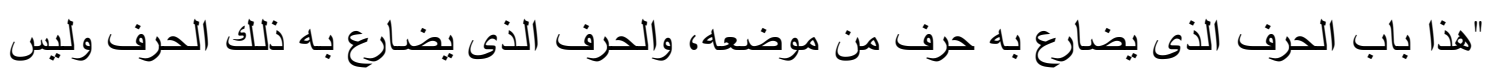
من موضععه". (£) وعلة التقريب بين الأصوات يوضحها في قوله: "إنما دعاهم إلى أن يقربوها (أى الصاد) ويبدلوها

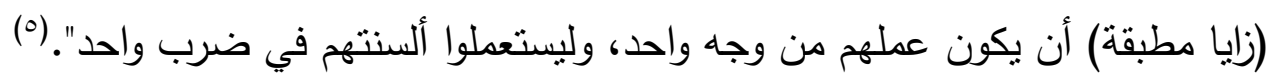

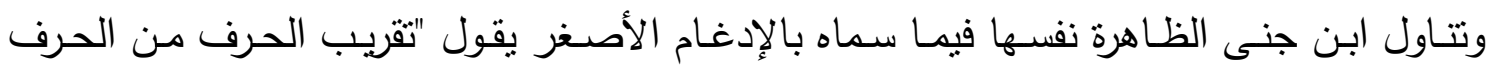

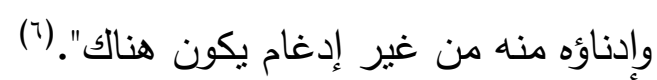

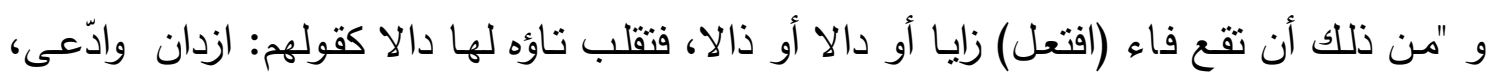

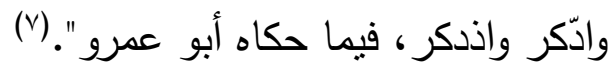

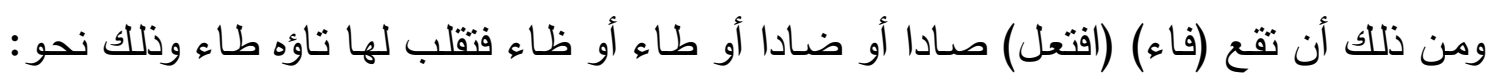

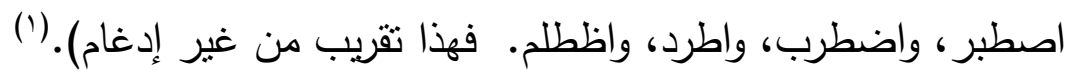

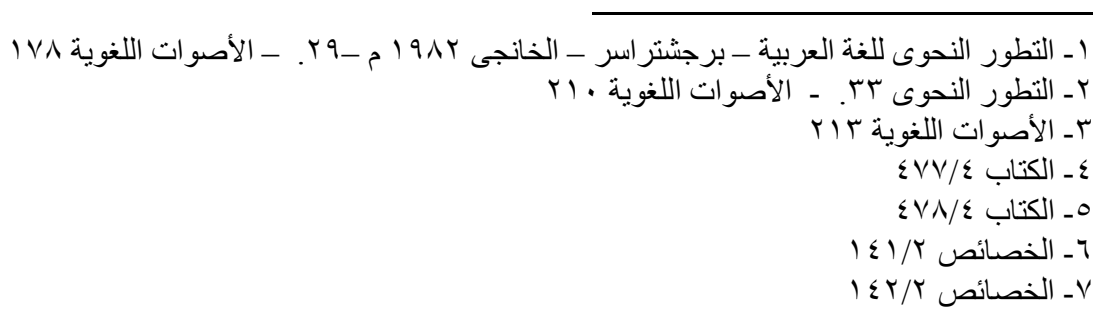


ومنه كذلك "تقريب الحرف من الحرف نحو قولهم في نحو مصدر : مزدر • وفى التصدير : التزدير.

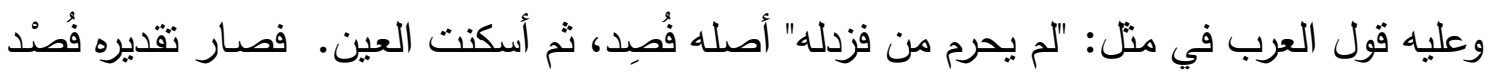

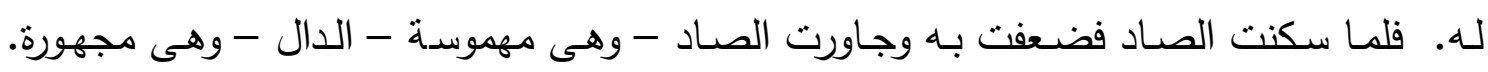

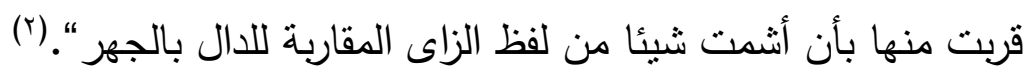

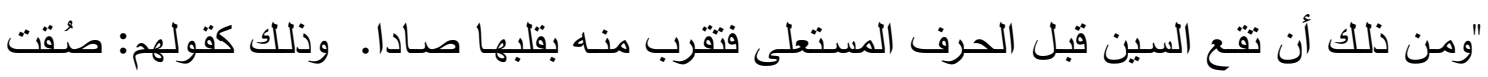
والصوق وصاخط، في سقت والسوق وساخط". (r)

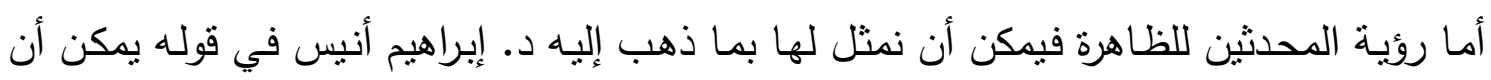
نقسم درجات الثأثز ونسبته إلى الموضوعات الآتية: 1- الجهر والهمس: إذا التقى صوت مهموس بصوت مجهور ، فقد يقلب أحدهما إلى نظير الآخر ، بحيث يتكون منهما صوتان مهموسان أو مجهوران.

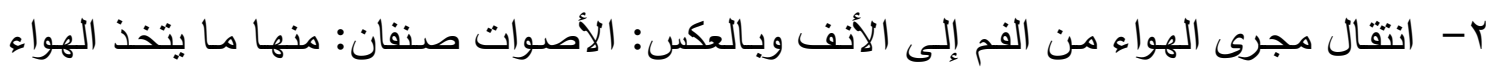

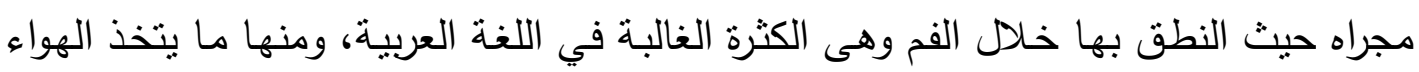

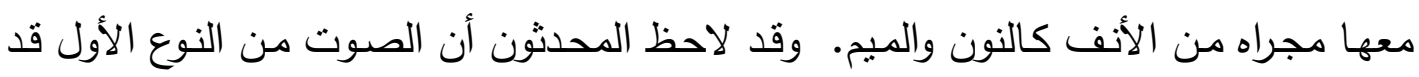

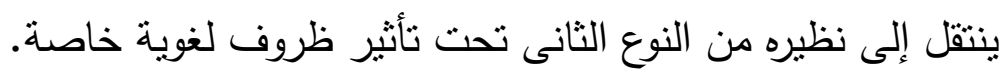

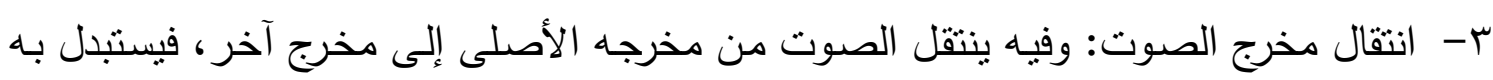
أقرب الأصوات إلبه في هذا المخرج الجديد.

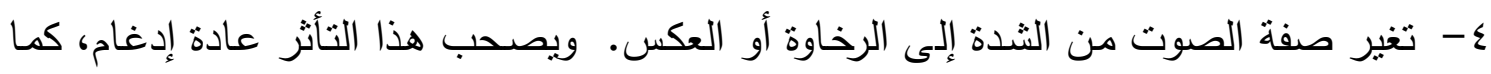

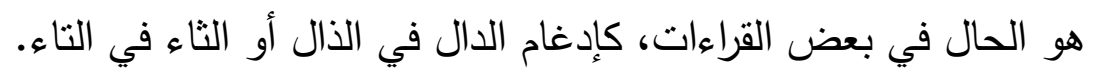

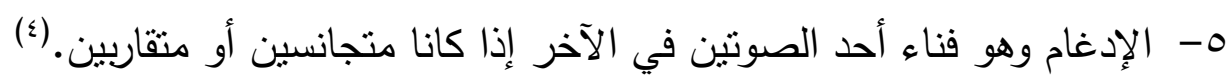

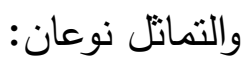
أ- اتباعى أو تقدمى Progressive: وفيه يتأثر الصوت الثنانى بـالأول كما في (ازدان) من (ازتان) حيث تأثرت التاء المهموسة بالزاى المجهورة فقلبت التاء دالا ليجتمع صوتان التانئ مجهوران.

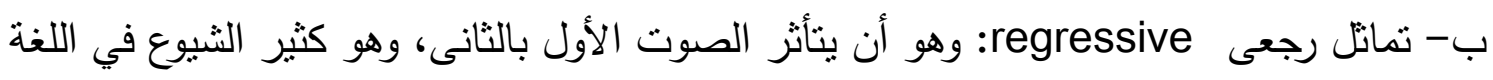

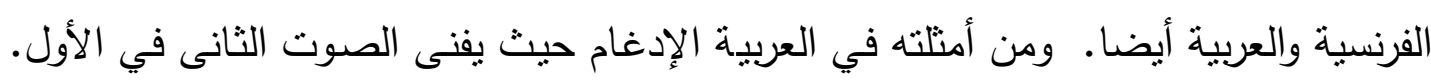

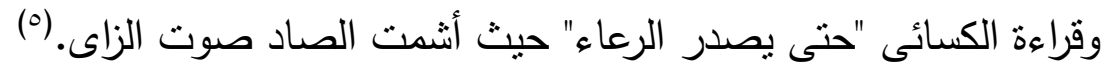


ونتحول الآن إلى بعض الاستخدامات اللغوية المعاصرة التى يمكن أن نستخدم ظاهرة التماثل في تفسيرها.

$$
\begin{aligned}
& \text { - يقولون: أخذه قصرا، وصوابها قسرا } \\
& \text { الصوق، وصوابها السوق } \\
& \text { - ويقولون: صور المدينة، وصوابها سور } \\
& \text { وصرة البطن، وصوابها سرة }
\end{aligned}
$$

فهذه النماذج من أمتلة التماتل بسبب تأثير الأصوات المستعلية.

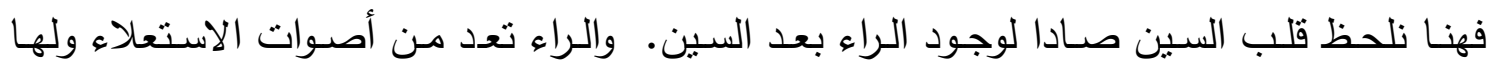
حكمها'(1).

- ميقولون: انشترت الماشية والصواب اجترت وهو مثل قولهم: فلان مشتهد في فلان مجتهد.

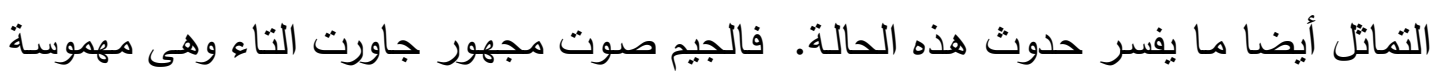

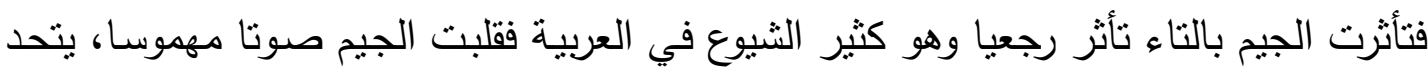

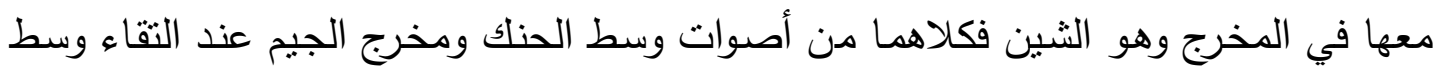

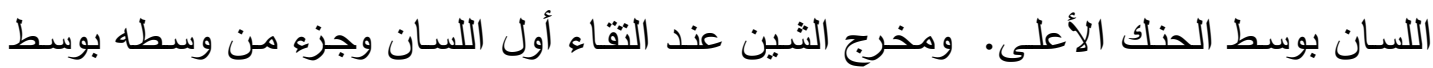

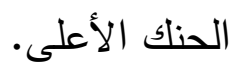

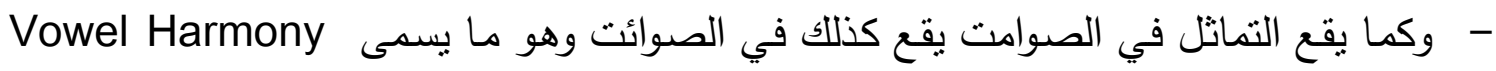

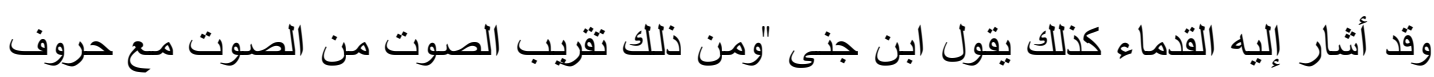

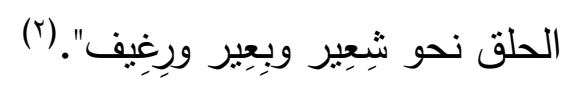

- "ومن ذلك أيضا قولهم (فَعَل يَفَعَل) مما عينها أو لامهـ حرف حلقى نحو سأل يسأل وقرأ يقرأ...

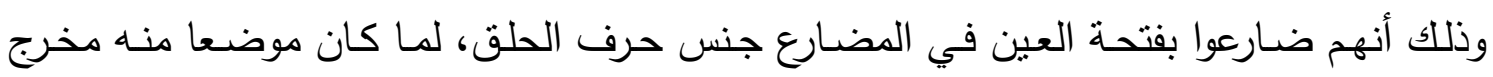

$$
\text { الألف التى منها الفتحة". (َ) }
$$

"ومن ذلك الإمالة. وإنما وقعت في الكلام لتقريب الصوت من الصوت، وذلك نحو عالم وكتاب

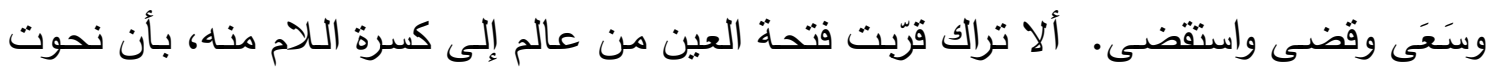

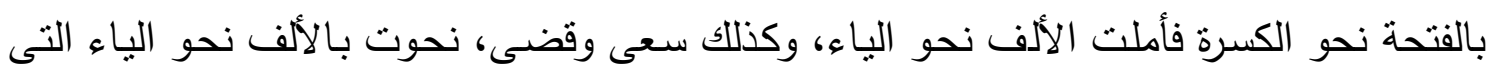
انقلبت عنها".(§) 
ويقول في سر الصناعة "واعلم أنك كما قد تجد هذه المضارعة وهذا التقارب بين الحروف، فقد تجده أيضا بين الحركات".(')

ويقول صاحب شرح المفصل "تقريب الأصوات بعضها من بعض لضرب من التشاكل"، (r)

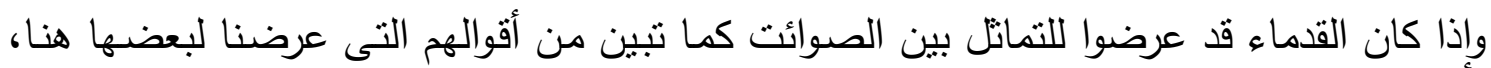

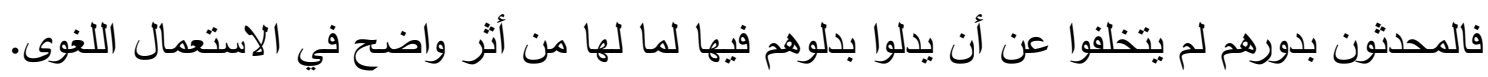

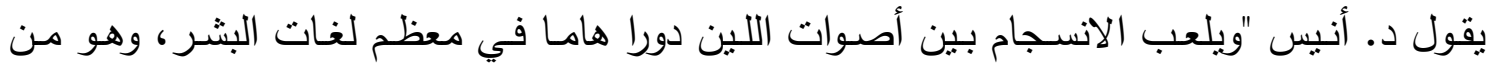

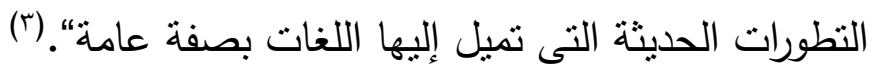
وإذا كان الباحث يرى هنا أن هذه الظاهرة من النطورات الحديثة فالصحيح أن الظاهرة قديمة وقد

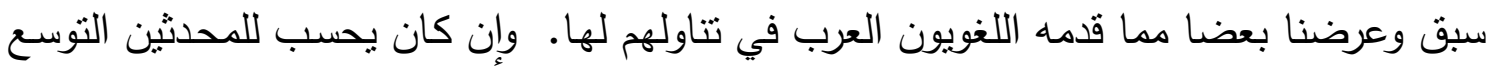
في عرض الظاهرة ومناقتتها وتقصيل القول فيها.

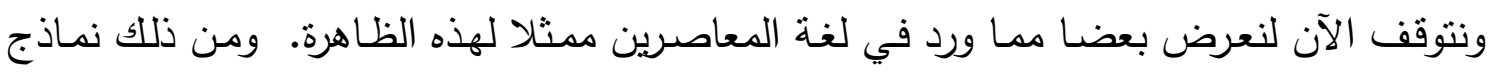

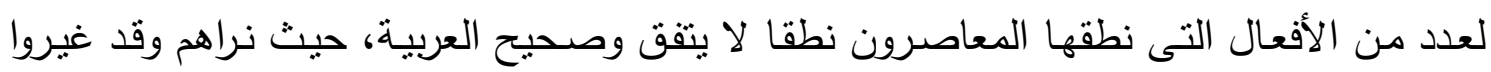

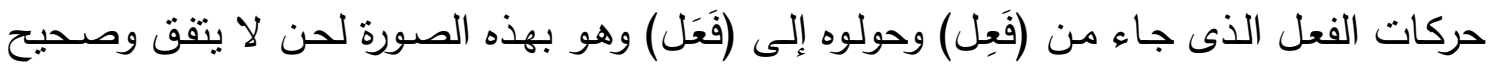

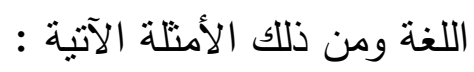
- يقولون: لحَس والصواب لحِس الحِ لَعَق والصواب لَعْق خَرَبَت والصواب خَرِبَتَ شَبَع والصوابَ شَبِع لَََس الثَوب والصواب لَبِسَ سَخَر منه والصواب سَخِر شَمَلَه الأمر والصواب شَمِله صَعَد والصواب صَعِد حَفَظ والصواب حَفِ رَغَبَ في والصنواب رَغَبَ

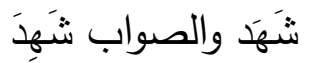
عَهَّْ والصواب عَهِيْ 


$$
\begin{aligned}
& \text { عَمَل والصواب عَمِلَ } \\
& \text { غَرَق والصواب غَرَق }
\end{aligned}
$$

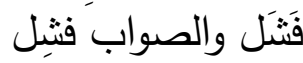

$$
\begin{aligned}
& \text { قَبَّل والصواب قَبِل }
\end{aligned}
$$

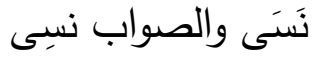

$$
\begin{aligned}
& \text { نَشَبَ والصوابَ نَنِب } \\
& \text { نَضَج والصواب نضِج } \\
& \text { نَفَد والصوابَ نَفَِ } \\
& \text { هَوَى (القراءة) والصواب هَوَى (القراءة) } \\
& \text { شَمَمَ الصواب شَمِمِ }
\end{aligned}
$$

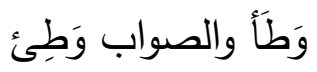

$$
\begin{aligned}
& \text { لَتَّم والصوابَ لَثِّ } \\
& \text { فَرَكَ (زوجها) والصوابَ فَرِك (زوجها } \\
& \text { سَمَن والصواب سَمِن }
\end{aligned}
$$

ومن التقريب بين الصوائت كذلك ما نراه من كلمات يتم الانتقال فيها من ضم إلى فتح أو من فتح إلى ضم تحقيقا للانسجام الصوتي ومن ذلك قولهم

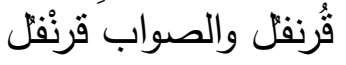

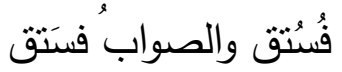
سُحُور والصواب سَحُور فُطوُر والصواب فَطُوُر زُكؤب والصواب رَكؤب دَوَّامة والصواب دُوَّامة

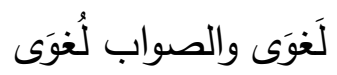
ومنه أيضا الإتيان بصائتين من جنس واحد على خلاف الأصل بغية تحقيق التماثل والانسجام بين الأصوات ومن ذلك دِمِشق والصوابِ دمَثقق

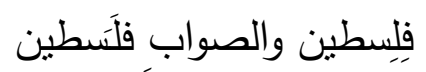
رِغِيف والصواب رِغِف 


$$
\begin{aligned}
& \text { شَتِعِير والصواب شَعِير } \\
& \text { بِعِدِ والصواب بَعِيد } \\
& \text { بِعِير والصواب بَعِير } \\
& \text { ومتله قولهم: وَتَدَ والصواب وَتَّد } \\
& \text { مَتَلة والصواب مِسَّة } \\
& \text { مَبَرد والصواب مِبَرد } \\
& \text { خَزَانة والصواب خِزَانة }
\end{aligned}
$$

ومن ذلك أيضا تحريك الساكن: يقولون للشر والجلبة: شَغَبَ والصواب شَغْب بإسكان الغين

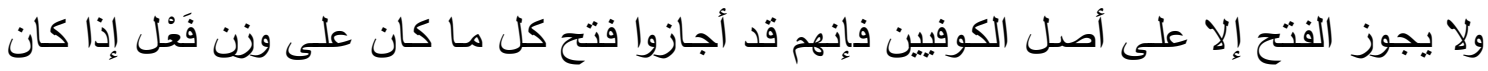

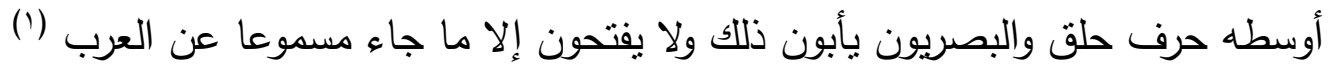

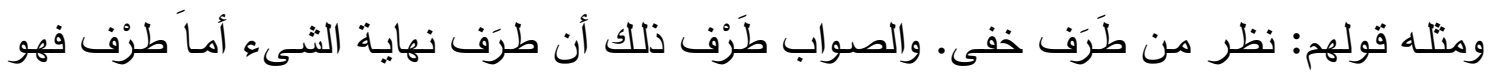

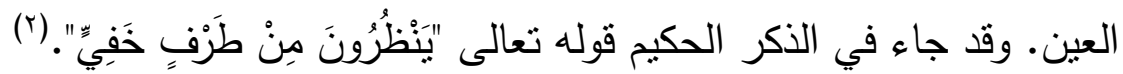

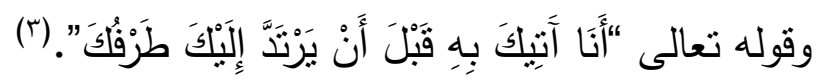
ويقولون حَلَقة والصواب حَلْقة بفتح الحاء وإِكَان اللام. وكذللك حَلْقة العلم وحَلْقة الخياطة، وكل

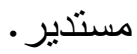

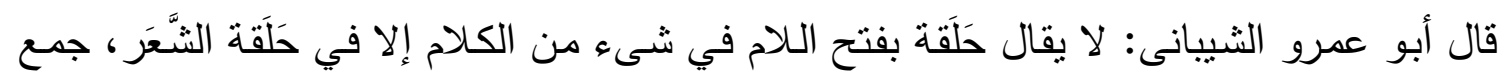

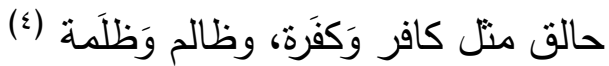

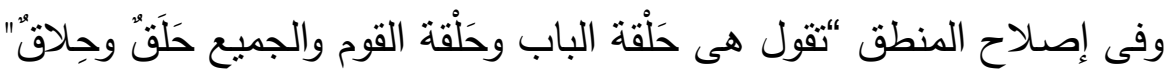

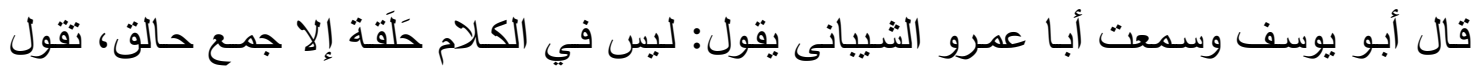

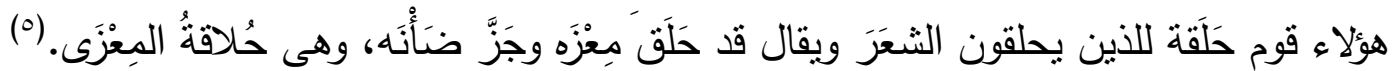

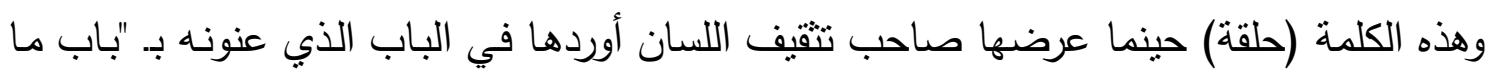

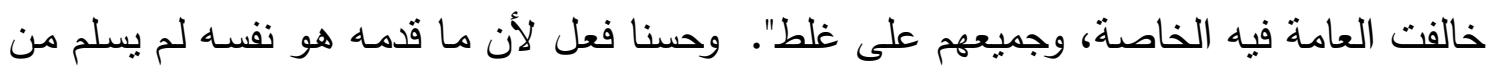

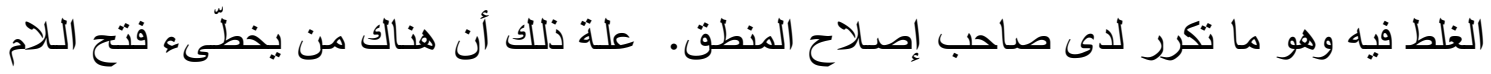

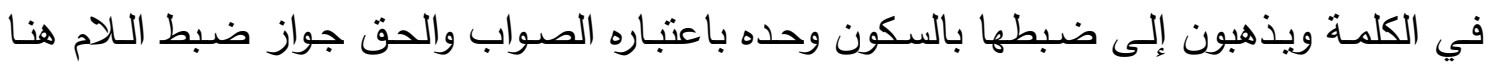

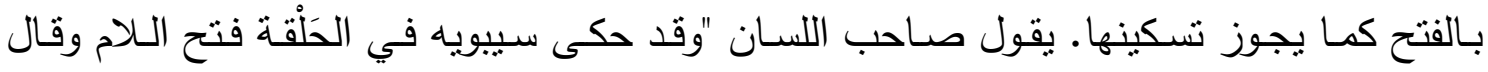

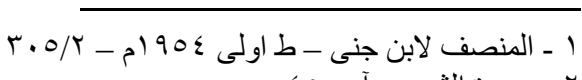

$$
\begin{aligned}
& \text { r - سورة الشورى آيه: } 0 \text { ـ }
\end{aligned}
$$

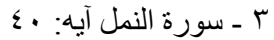

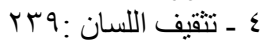

$$
\begin{aligned}
& \text { ه ـ إصلاح الهنطق لابن السكيت: كما }
\end{aligned}
$$




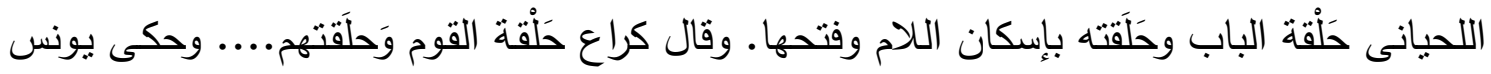

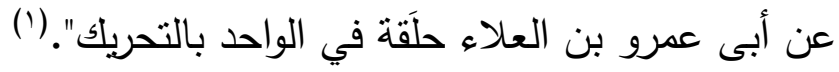

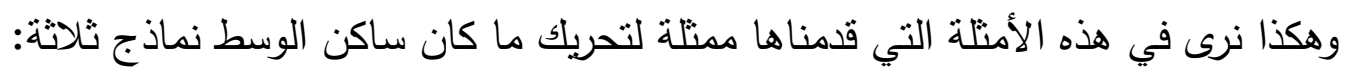
الأول: كما في الثَغَب يجوز تحريك عين الكلمـة على مذهب الكوفيين لكون عين الكلمـة أحد حروف الحلق وهو هنا (الغين). الثاني: كما في طرْف هي بسكون الوسط وتحريكها يخرجها عن الصواب في بابها لأن الطرْف بمعنى العين ليس إلا بالسكون. فإن تحركت الراء تحولت إلى صيغة أخرى ومعنى آخر وبذللك يكون تحريكها في السياق لحن ينبغي النتزه عنه. الثالث: كما في (حلقة) بسكون اللام وتحريكها دون مفاضلة فصحيح اللغة يقبل الحالتين. 


\section{المخالفة}

إلى جانب ظاهرة التماثل تأتى ظاهرة المخالفة التي تعالج قضية التجاور بين الأصسوات وتأثثر بعضها ببعض سواء أكان ذلك بين الصوامت أو الصوائت. والمخالفة تعنى حدوث اختلاف بين الصوتين المتماتلين في الكلمة الواحدة حيث يقلب أحدهما إلى إلى

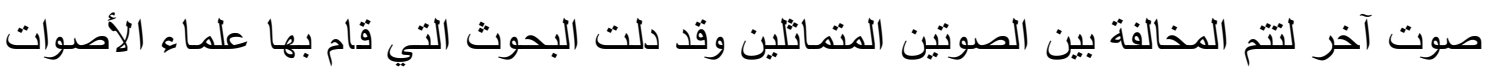
أن ظاهرة المخالفة قد شاعت في كثير من اللغات السامية وليست هذه الظاهرة إلا تطورا تاريخيا

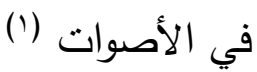
"والتخالف نادر بالنسبة إلى التثابه وهو نادر في اللغة العربية، بالنسبة إلى بعض اللغات السامية

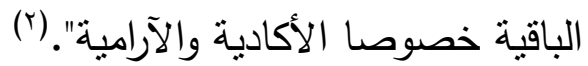
وكما كان لظاهرة التماتل حضورها لدى اللغويين القدماء كان لظاهرة المخالفة حظها من الحضور والتتاول يقول سييويه: باب ما شذ فأبدل مكان اللام ياء لكراهية التضعيف. وذكر من ذلك تسريت وتظنيت وتقصيت من القصة. (r)

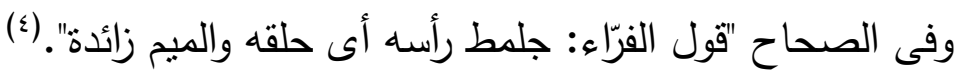
وفى المزهر"ومن المضاعف قال أبو عبيدة: العرب تقلب حروف المضاعف إلى الياء ومنه قوله

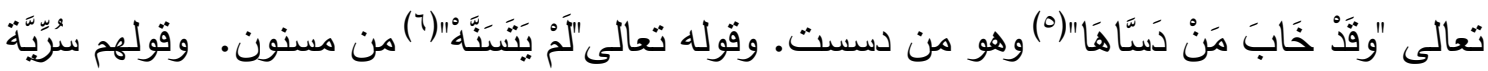

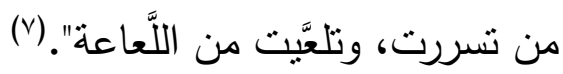
وفى الأمالى للقالى يقول "حسن بسن" إن لفظ بسن من البسّ وأن النون بدل من حرف التضعيف،

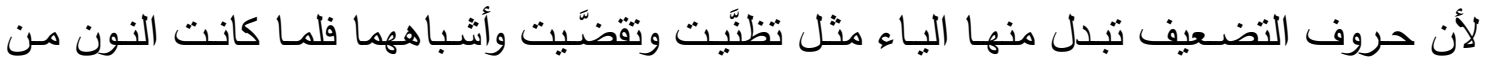

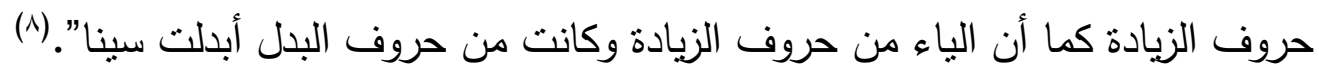
وفى خصائص ابن جنى جاء قوله "باب قلب لفظ إلى لفظ بالصنعة والتلطف" ومنه قول العرب:

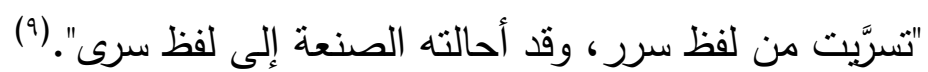

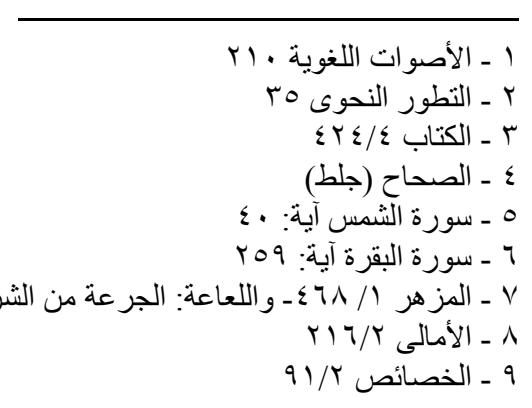


ومن الأمثلة التي أبدل فيها أحد الحرفين المضعفين راء أو لاما ما رواه ابن فارس الفرقعة: "تتقيض

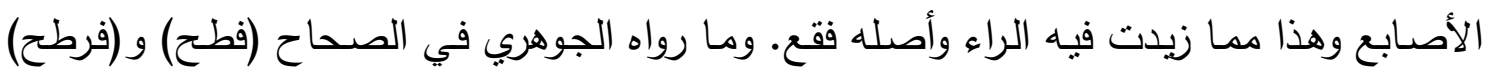

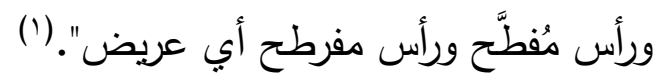
وبعد أن عرضنا لروئة القدماء والدحثثين لظاهرة المخالفة نعرض لبعض الحالات التي جاءت ممنلة لهذه الظاهرة في العربية المعاصرة ومن ذلكاه - قولهم: قصيت أظفارى وهى من المسموع عن العرب القدماء وذكرها ابن جني في قوله “ومنلها:

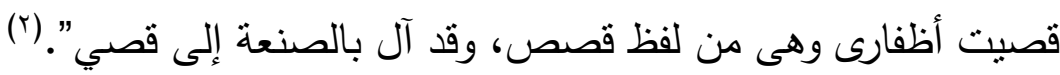

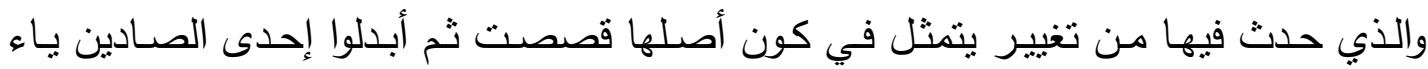
والكلمة وإن كانت موجودة في العربية المعاصرة فلها جذورها العربية ومروية عن العرب ولذلك ذهب صاحب تثقيف اللسان إلى عدها صحيحة غير ملحونة وذللك في قوله: "قصيت أظفارى"،

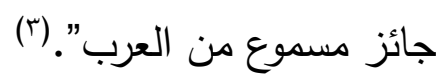

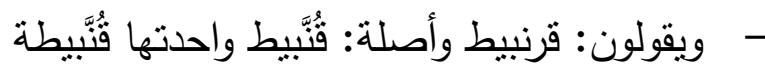
جاء في المعجم الوسيط: القُنَّبط: بقلة زراعية من الفصيلة الصليبية تطبخ وتؤكل، وتسمى في مصر والثام قرنبيط() والذى حدث في قُبَّبط تغاير حيث أبدل من إحدى النونين راء، والراء أحد الأصوات الثبيهة بأصوات اللين والتى تعامل معاملتها ومن ثم نشأ بعد الإبدال قرنبيط على لهجة الناطقين في مصر والثنام على ما جاء في الوسيط - ميقولون للثيء المنبسط مفلطح. والأصل هو مفطَّح.

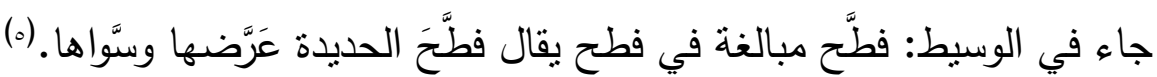

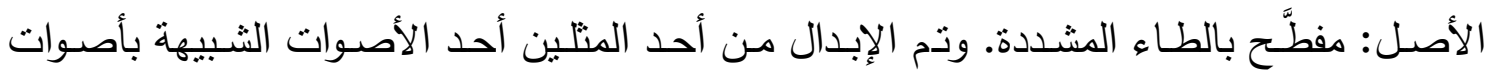

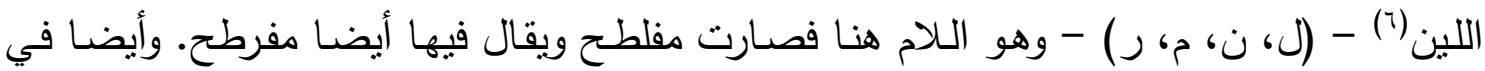

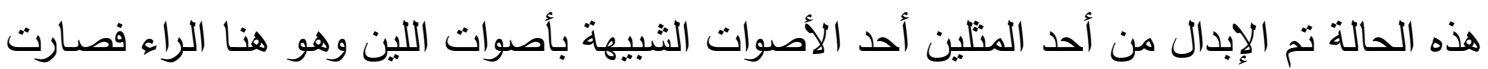

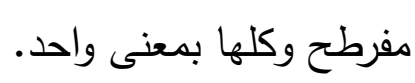

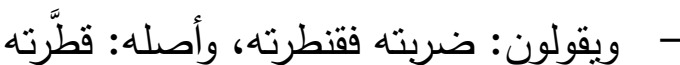

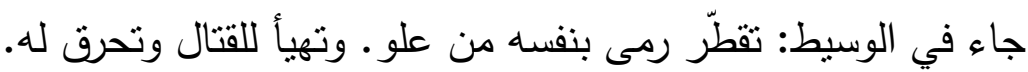

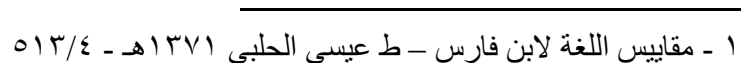

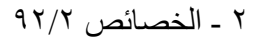

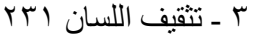

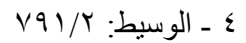
O ـ السابق: T ـ الأصوات اللغوية VV 
قطرّته: وقع التبادل بين أحد المنلين وبين النون ليتم التغاير بينهما وتصير قنطر . والنون كما سبقت الإثارة أحد الأصوات الثبيهة بأصوات اللين وهو ما يجيز إبدالها فئن في مثل هذه

- يقولون فرقع أصابعه، وأصله فقّع والفرقعة: تتقيض الأصابع

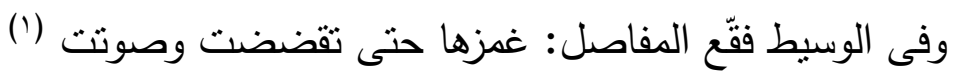
المغايرة وقعت نتيجة التبادل بين أحد المتلين والراء، والراء أحد الأصوات الثبيهة بأصوات الثبط اللين وهو ما جوز إبدالها. والكلمة بعد ذلك من المروى المسموع عن العرب وهو ما يعنى أن الكلمة لها جذورها القديمة في العربية (ץ)

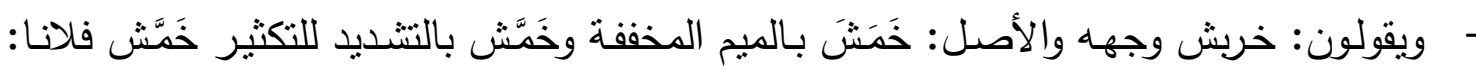
جرح بشرته في أى موضع من جسده. (r) ويمكن تفسير ذلك تبعا لقاعدة التغاير على النحو الاتى:

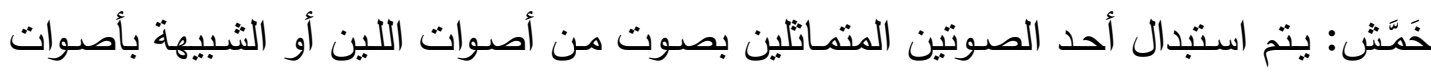

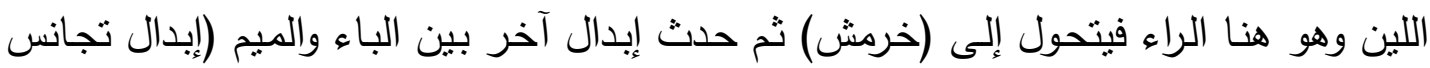

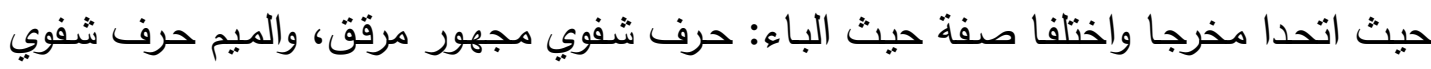
منوسط أنفى). وبهذا الإبدال بين الراء وأحد الميمين صارت خرمش وبإبدال الميم باء أصبحت خرش. فالتغاير هو التفسير لما حدث في الكلمة من تغيير.

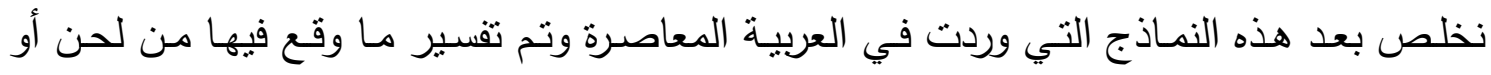

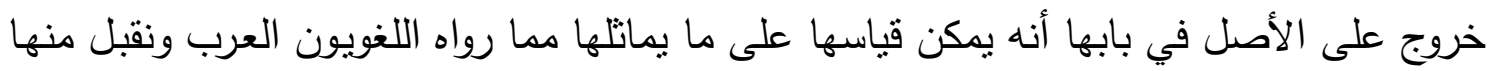
ما اعترفوا بفصاحته وصحته منها، وما جاء غير ذلك إن كان له وجه من العربية يمكن تخريجه الاهله

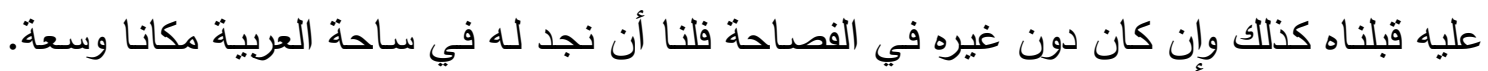

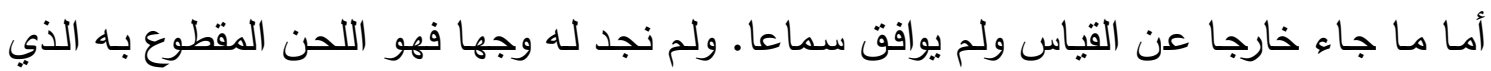
يجب طرحه ونبذه وعدم التهاون في رفضاء 
النبر مصطلح صوتي يقصد به الضغط على صوت أو مقطع معين عند النطق به فيكتسب هذا

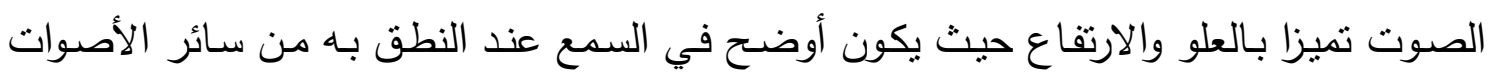

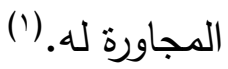

هذا الضغط يبرز الصوت وهذا البروز يتحقق عندما يكون الصوت أوضح وأطول وأعلى ومتميزا

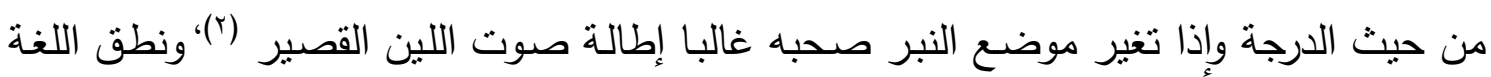

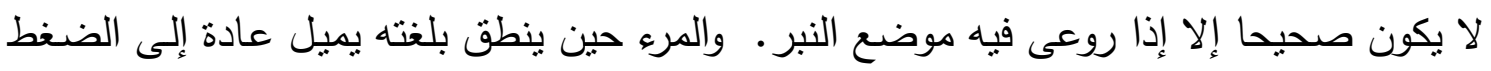

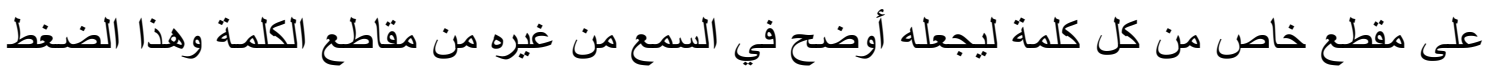

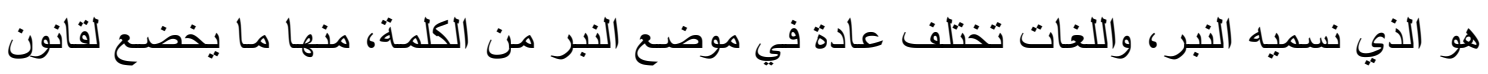

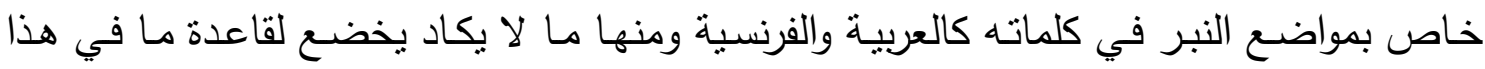
كالإنجليزية. فالفرنسى يضغط عادة على المقطع الأخير من كل كلمة. (r)

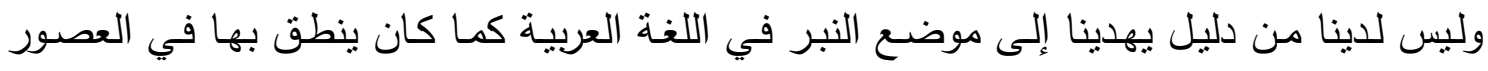

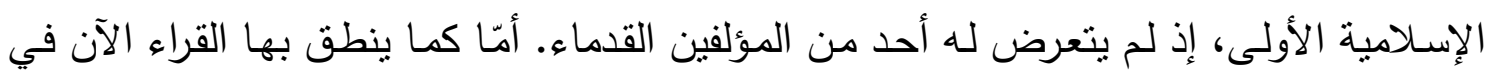

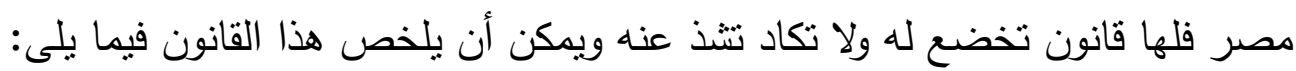

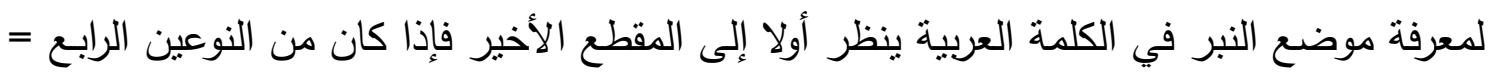
صامت + صائت طويل + صامت (بانْ). أو الخامس = صامت + صائت قصير + + صامنان (بُنّ).

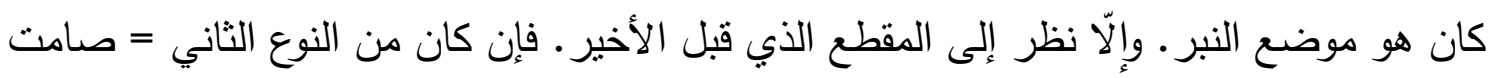

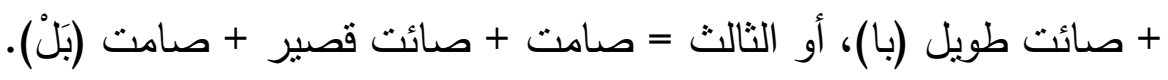

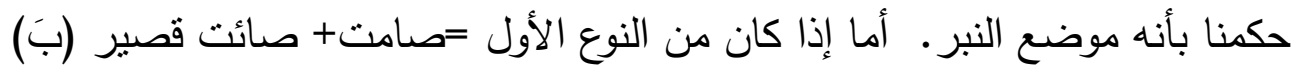

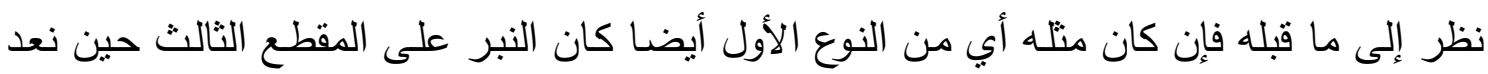

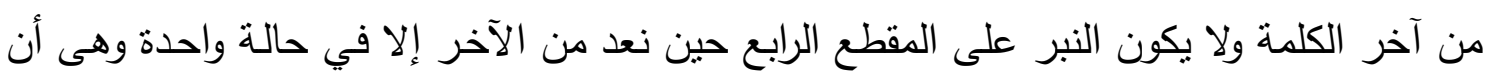

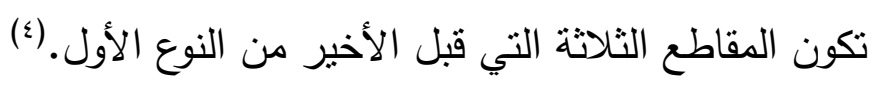

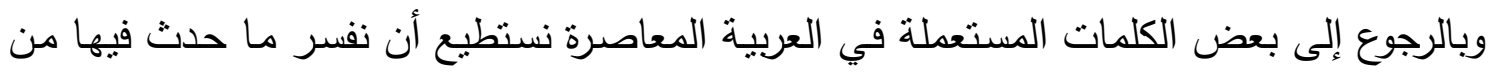

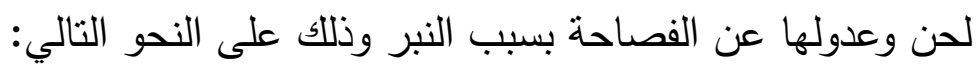

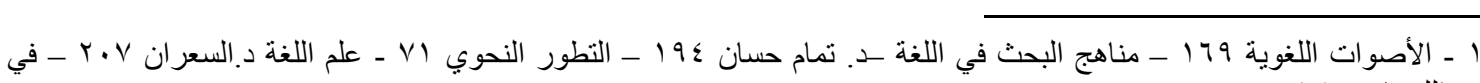

$$
\begin{aligned}
& \text { ا اللهجات }
\end{aligned}
$$

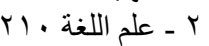

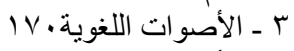

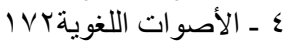




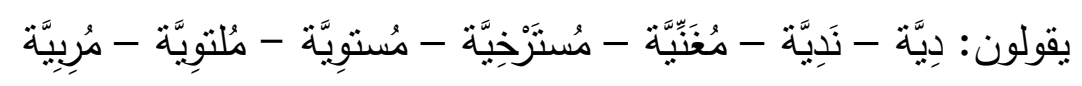

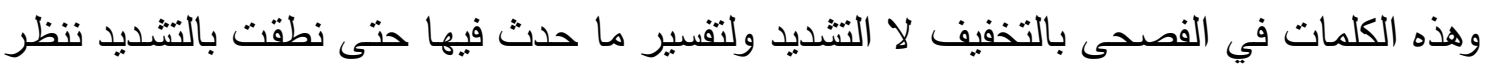
في بنية الكلمة في الفصحى وبنيتها في حالة اللحن وهو ما يكثف عن أسباب هذا التغير.

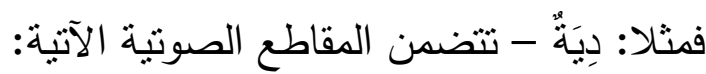

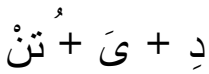
صامت + صائت قصِير / صامت + صائت قصِير / صامت + صائت قصِير + صامت.

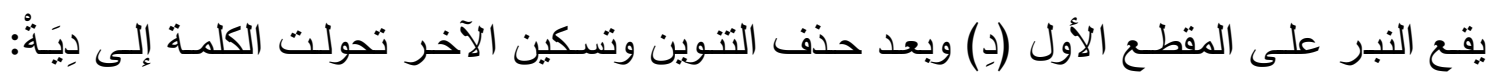
تتضمن المقاطع الصوتية الآتية

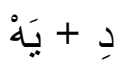

$$
\text { صامت + صائت قصِير / صامت + صائت قصِير + صامت }
$$

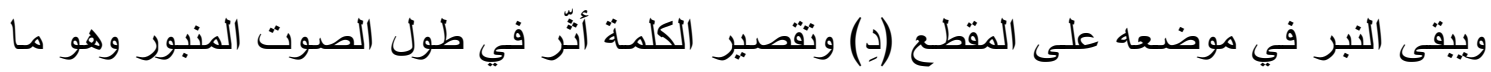

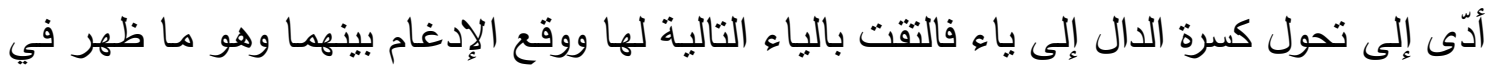

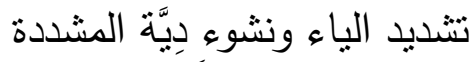

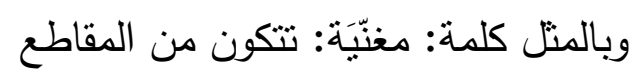

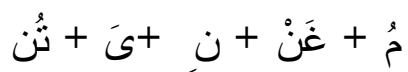

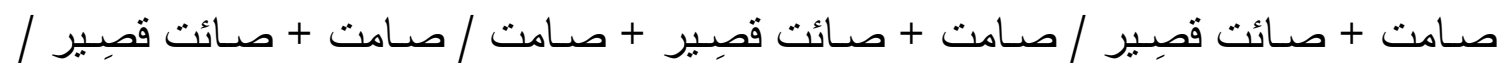

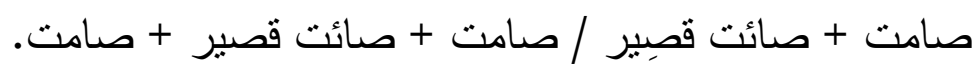

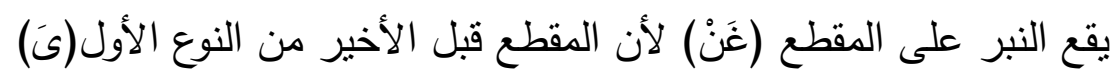

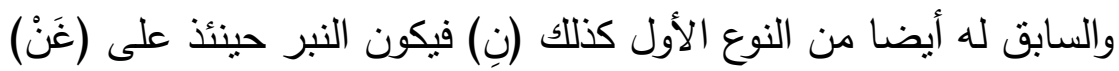

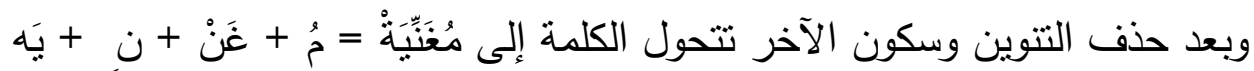

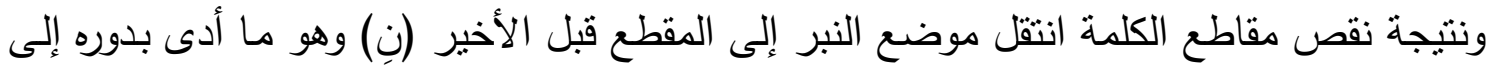

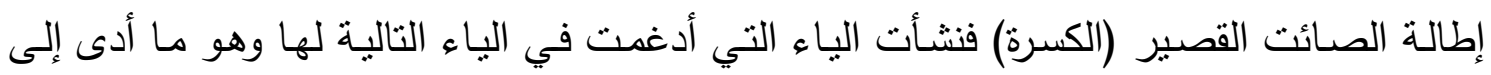
التشتديد فكانت مُغَنَيَّة بالتشنديد

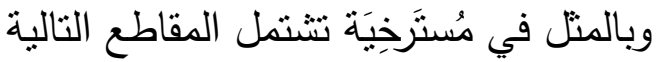

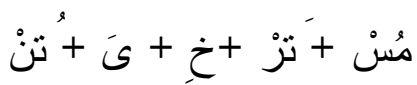

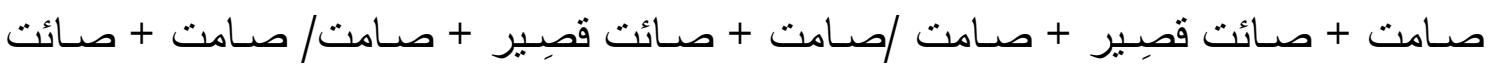
قصِير / صامت + صائت قصِير / صامت + صائت قصِير + صامت 


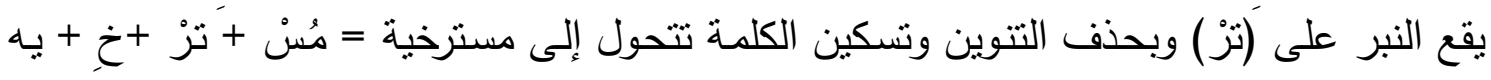

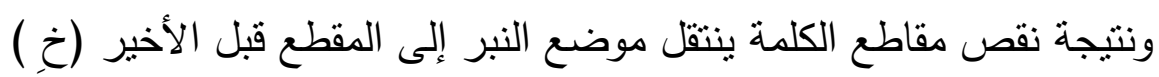
ونتيجة لوقوع النبر عليه يطول الصائت القصير (الكسرة) فتتنج الياء التي تدغم بدورها في الياء

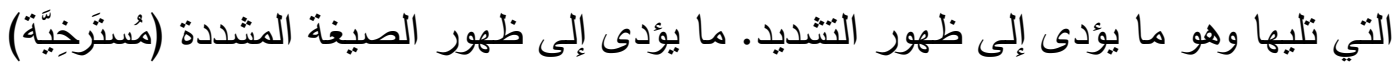

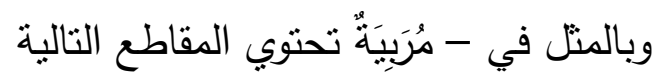

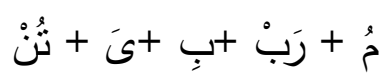

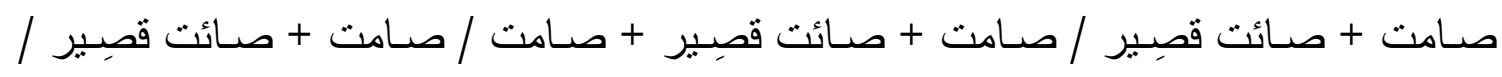

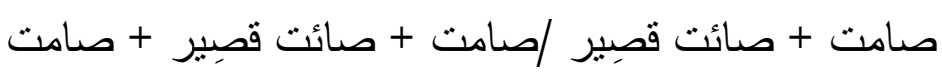

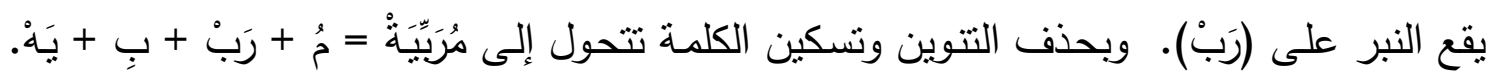

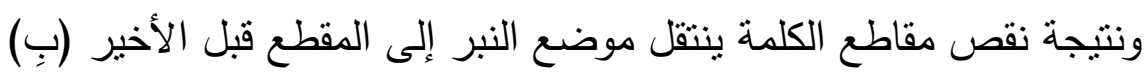

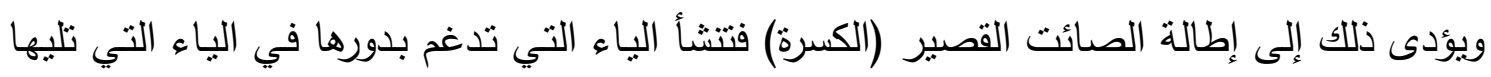

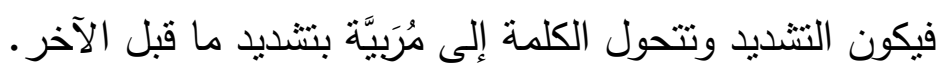

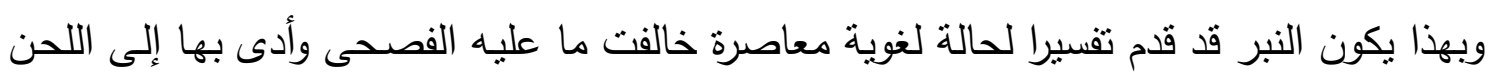

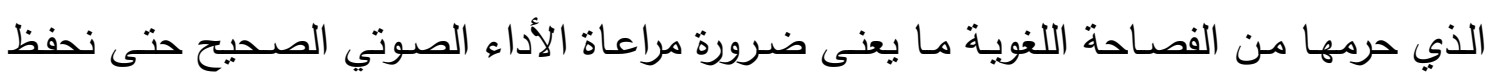
على اللغة: أصواتها وأبنيتها ودلالاتها بعيدا عن تغول اللحن وفساده. 


\section{الخاتمة}

حاولت هذه الدراسة أن تقدم تفسيرا صوتيا لبعض مظاهر اللحن في اللغة العربية المعاصرة وذلك من خلال عرض بعض النماذج وإخضاعها للتحليل وقد بدأت خطة البحث بتقديم تحديد لمفهوم اللحن لغة واصطلاحا وتحديد المعنى الذي قصدناه في هذه الدراسة وهو يعنى الخطأ في اللغة: أصواتها وصرفها ونحوها ودلالاتها ورجحت أن استخدام لفظ اللحن بهذه الدلالة قد بدأ منذ الجاهلية وصدر الإسلام ولم يتأخر إلى نهاية القرن الأول الهجري كما ذهب إلى إنى ذلك بعض النه الباحثن.

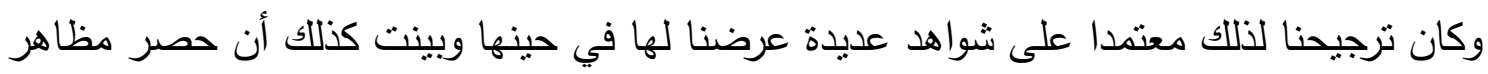

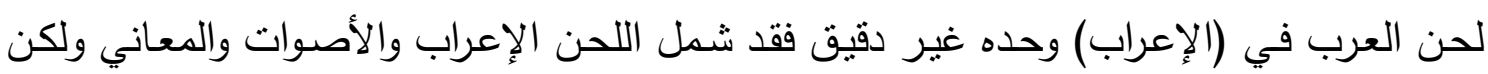

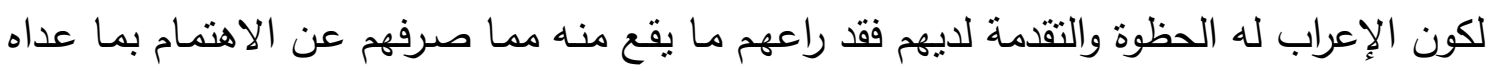
دون أن يكون ذلك دلبلا على عدم مظاهر اللحن الأخرى، وهو ما ينسحب بلدوره على مظاهر

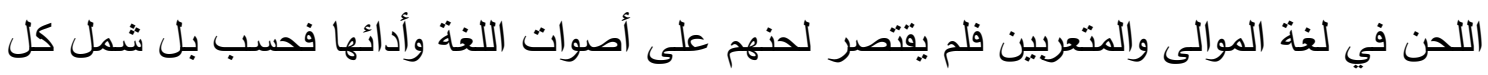
مستويات اللغة الصوتية والصرفية والنحوية والدلالية وإن كان الجانب الصوتي قد مثل أبرز مشاهد

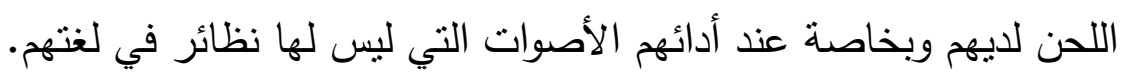
ثم انتقل البحث إلى تتاول قضدية مقياس الفصاحة وصلتها بالمستوى الصوابي الذي يحدد معيار الخطأ والصواب في اللغة وقد اتضح مدى التفاوت بين اللغويين في تحديد هذا المعيار أو القياس.

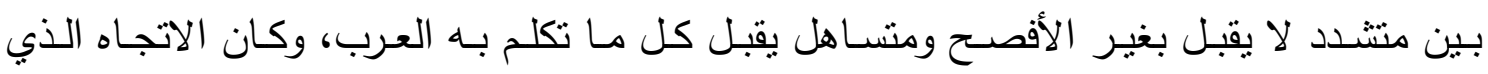

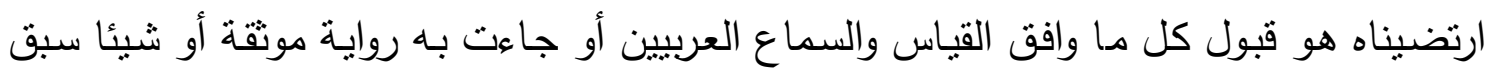
إليه عربى فصيح غير متهم وقد فضلت هذا النهج رغبة في تخفيف وطأة القيود المتثددة وأن يكون ذللك بمثابة محاولة جادة في تقريب اللغة من أبنائها عن طريق التيسير في قبول فئه فل فئ استعمال لغوى ما دام يحفظ على اللغة صحتها وفصاحتها. ثم كان التتاول لبعض مظاهر اللحن في العربية المعاصرة التي حاولنا تفسيرها تفسيرا صـوتيا يكثف عن أسباب انحراف هذه الحالات مما أخرجها على صحيح اللغة وكانت البداية مع الإبدال

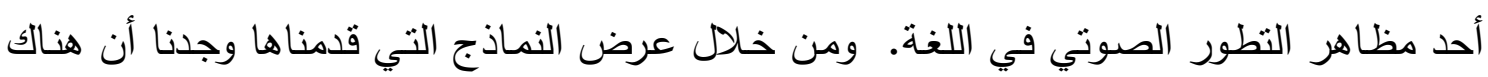

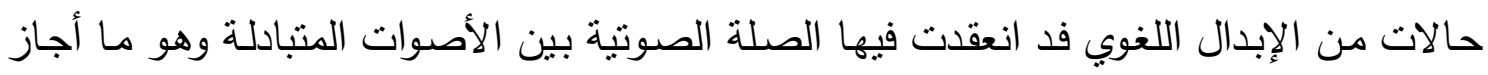

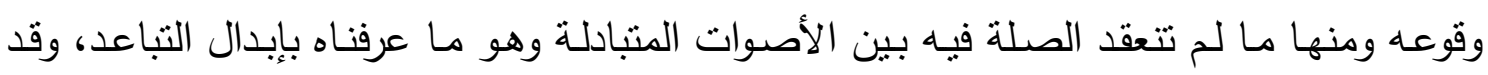
اتضح أن الإبدال اللغوي يقع في الصوامت كما يقع في الصوائت.

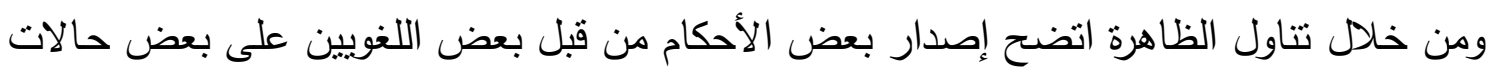

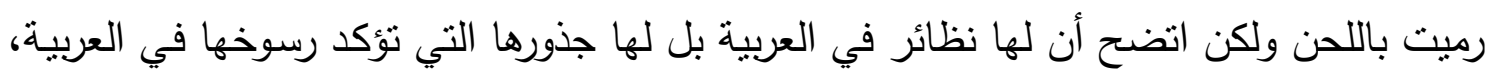


وهو ما تمثل في أكثر من حالة كما في كلمات أسقطت منها الهمزة ورميت باللحن بينما أثنتتا أن

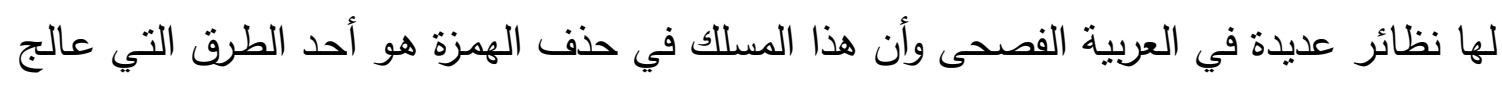

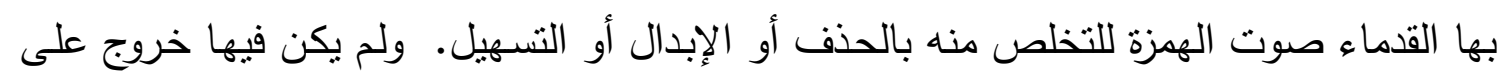

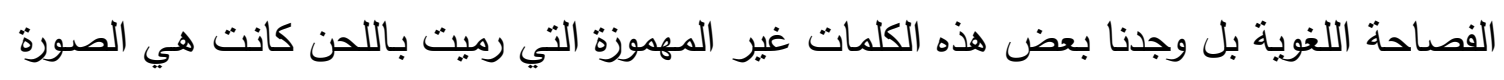

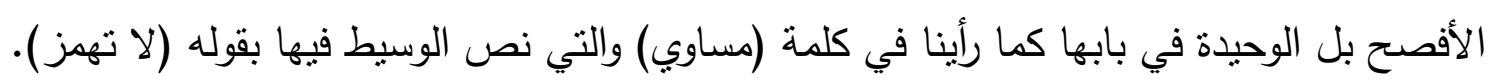

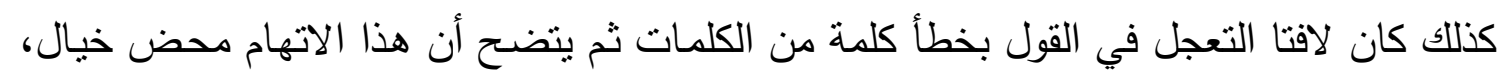

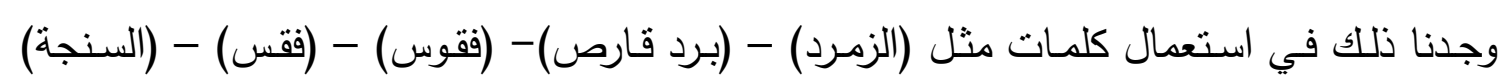

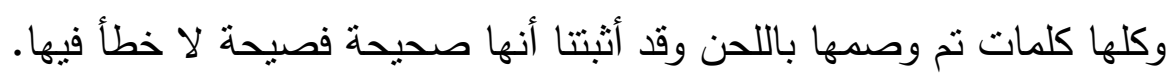

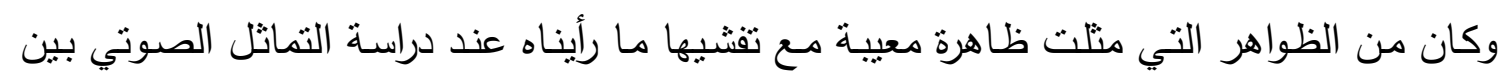

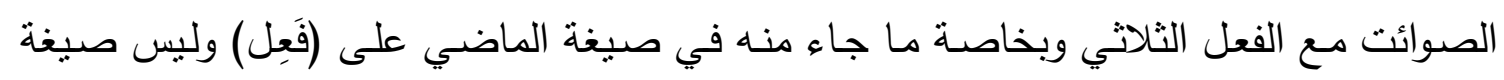

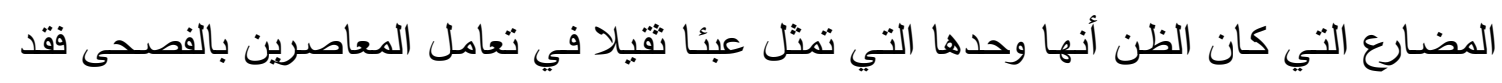

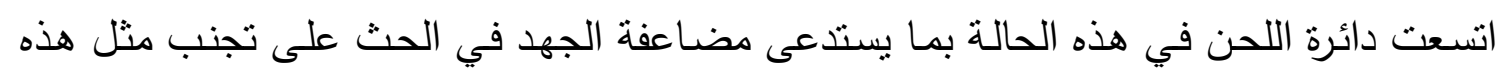

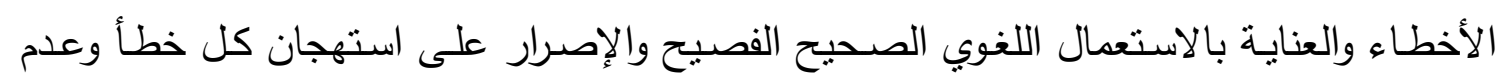
القبول به أو التجاوز معده. كذللك وجدنا في حالات تحريك الكلمات الثلاثية ساكنة الوسط أن هذا التحريك لم يكن كله لحن

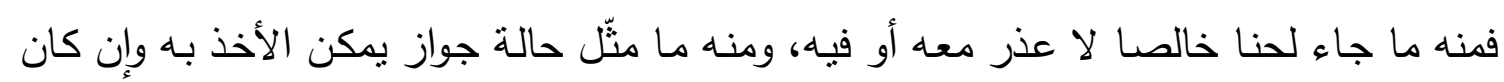

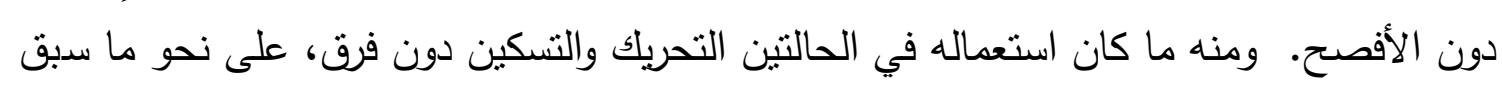

$$
\text { أن عرضنا له كما في (الطُرَف - الثَغَبَ - حلقة). }
$$

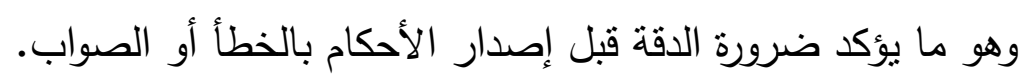

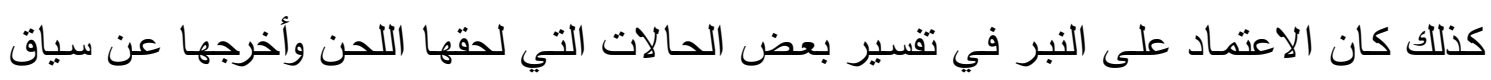
الفصحى على النحو الذي عرضنا له فيما سبق. وهو ما يدعو إلى ضرورة مراعاة النبر في استعمالنا اللغوي لما يترتب عليه من إخلال بيينة الكلمة

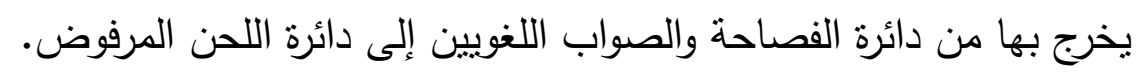

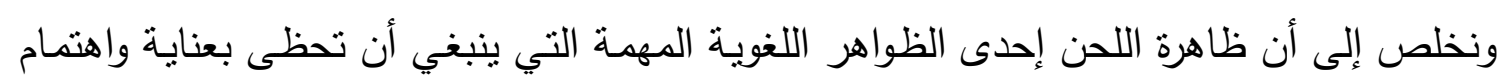

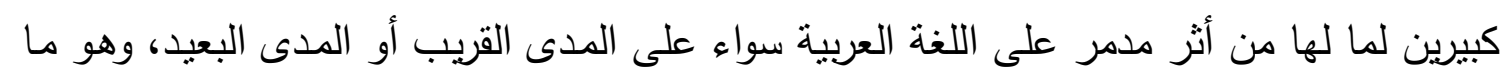

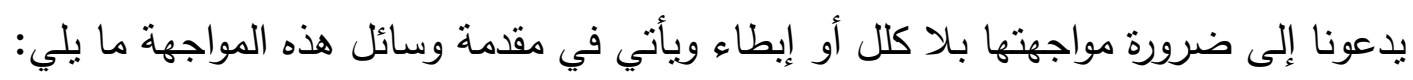

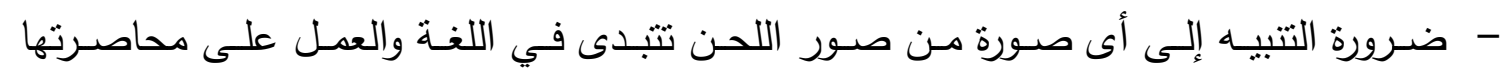
والتخلص منها والتأكيد على رفضها وعدم السماح بالتجاوز في التعامل بها. 
- ينبغي أن يكون لمجهع اللغـة العربيـة بمصر دور نافذ ولقراراته وتوصياته قوة الإلزام وعدم

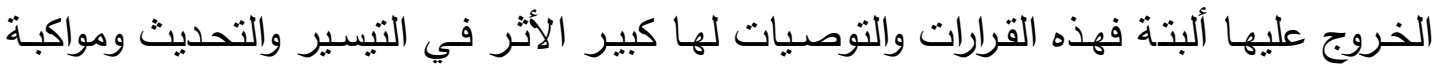
العصر دون التفريط في الفصاحة اللغوية وأيضا دون التتدد الذي قد يحول بينها وبين أهلها.

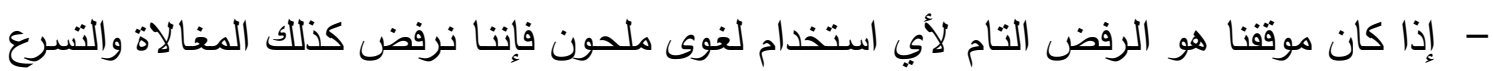

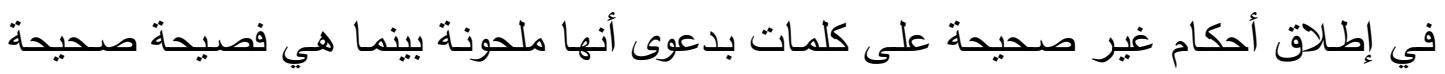

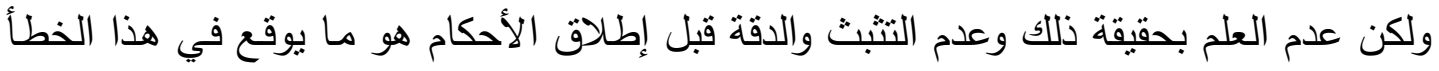
الجسيم وهو خطأ فادح لأنه يحرم العربية من كلمات تزيد من ثروتها اللفظية وتنساعد في نموها وتطورها. - ونا. - الدعوة إلى ضرورة أن تلتزم البرامج المسموعة في الإذاعتين المسموعة والمرئية في برامجهما

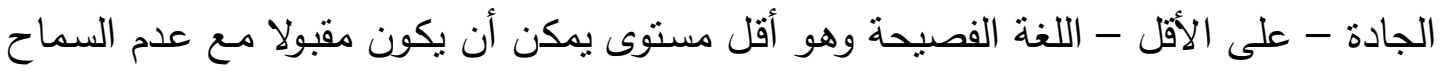
بالعبث بهذه القاعدة تحت أي مسمى أو مبرر . - كذلك يجب أن يلتزم كتاب المقالات في الصحف والمجلات الفصاحة اللغوية في كتاباتهم وعدم

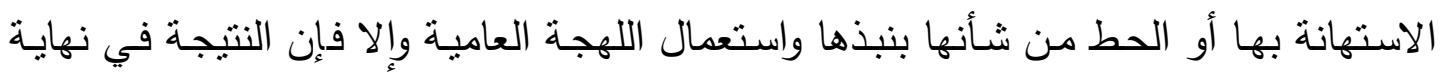
المضاف ستؤدى إلى استشراء آفة اللحن بما يحول بيننا وبين التخلص منه أو القضاء عليه. وأخيرا أرجو أن يكون هذا الجهد المتواضع لبنة من لبنات مقاومة هذه الظاهرة المنكرة ومحاولة لهنة

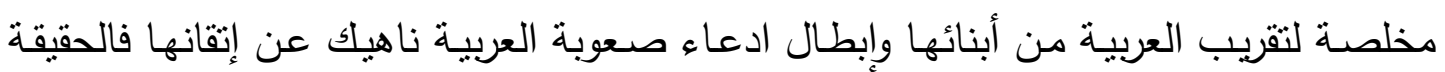
تنبئ بغير ذلك.

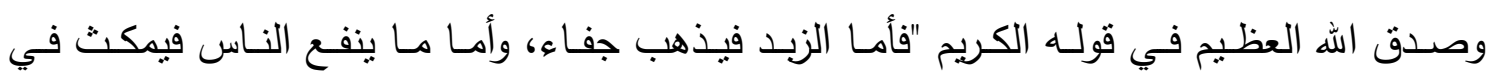

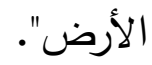
والله أدعو أن ينفع بهذا الذي قدمت ويفيد إنه نعم المولى ونعم النصير . 


\section{المراجع}

1- أساس البلاغة - أبو القاسم جاراله محمود الزمخشري - ت: محمد باسل عيون السود - دار

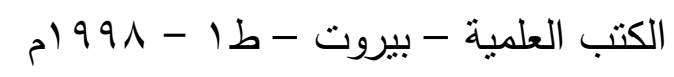

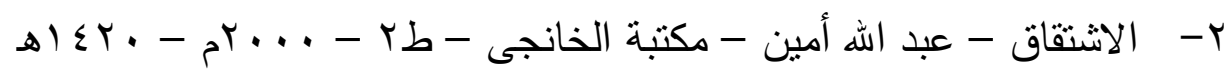

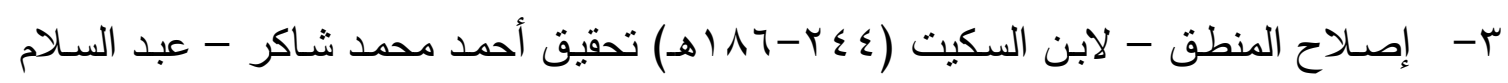

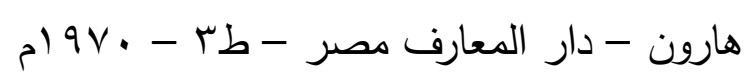

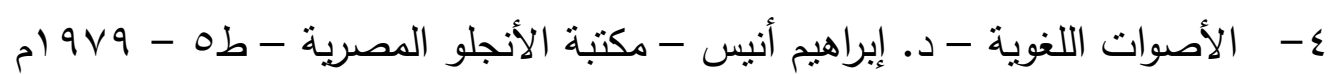

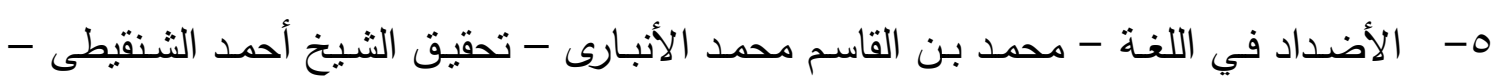

المطبعة الحسينية

צ- الاقتراح في علم أصول النحو - جلال الدين السيوطي - تحقيق د.أحمد محمد قاسم طا-

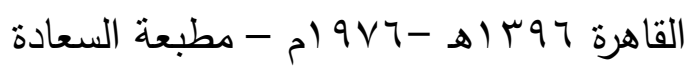

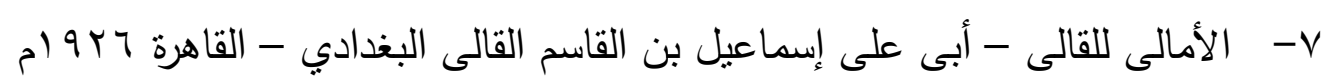

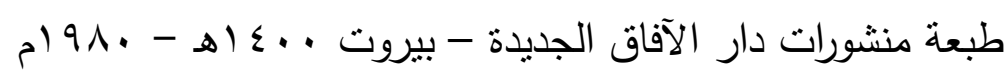

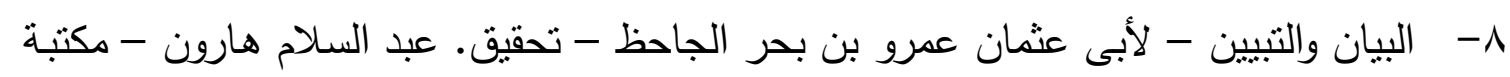

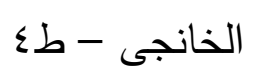

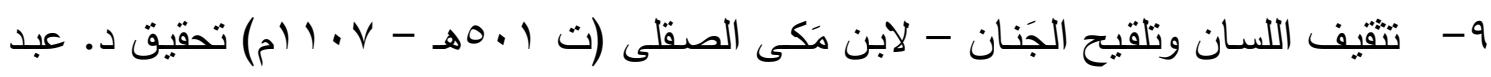

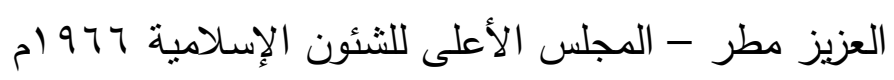

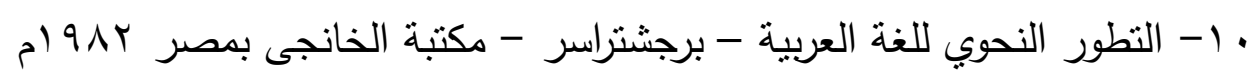

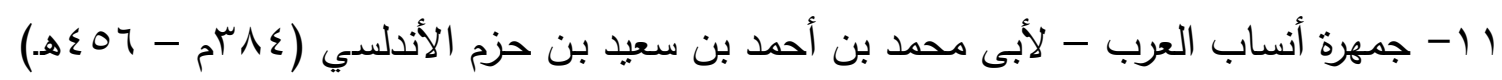

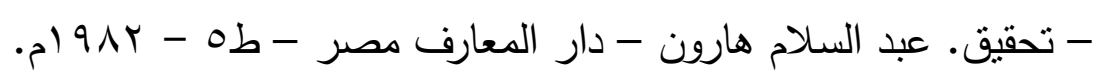

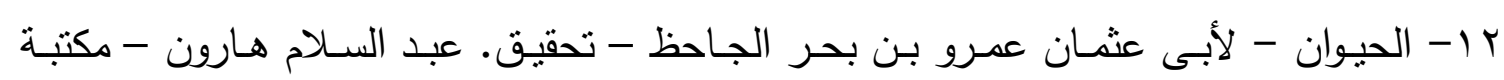

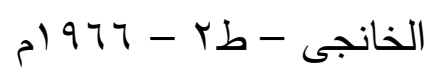

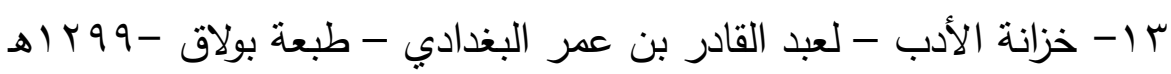

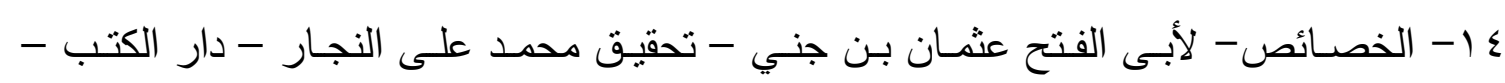

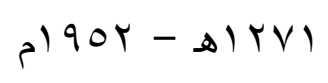

10- دراسات في فقه اللغة - د. صبحي الصالح - الطبعة التاسعة - دار العلم للملايين - بيروت 
17 - سر الصناعة - لأبى الفتح عثمان بن جني - طبعة الحلبي - طا - تحقيق مصطفى السقا - محمد الزفزاف - إبراهيم دصطفى - عبد اله أمين - الجزء الأول IV

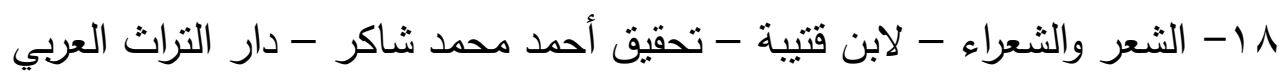

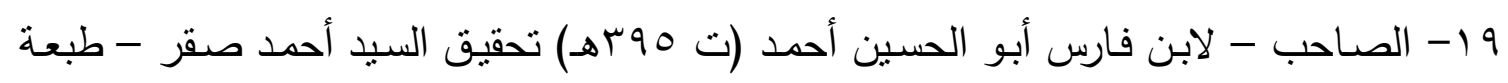
الحلبي $9 V V$

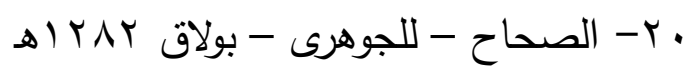
اب- طبقات الندويين واللغويين - لأبى بكر محمد بن الحسن الهن الزُّبيدى الأندلسي- تحقيق محمد

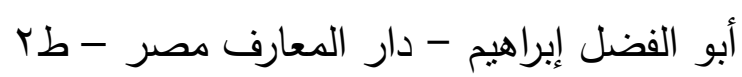

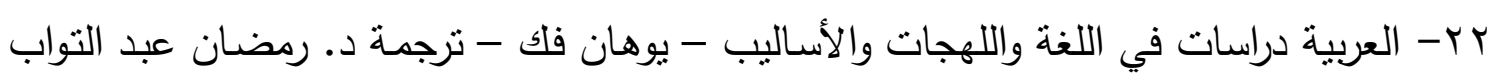

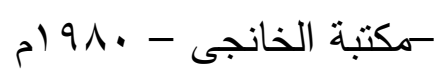

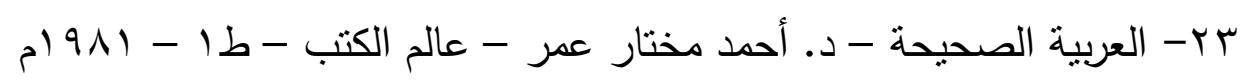

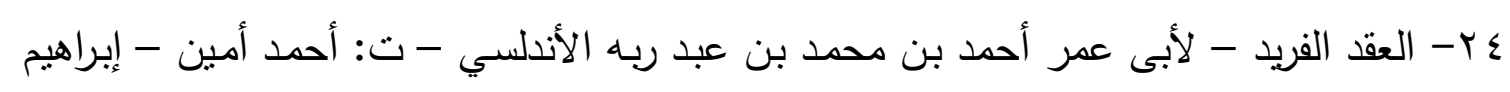

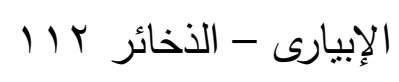

0r- علم اللغة مقدمة للقارئ العربي - د. محمود السعران - طا - دار المعارف

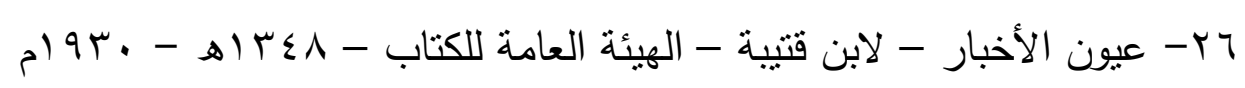
VV

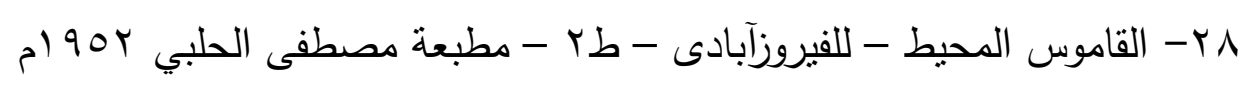
وץ- الكتاب - لأبى بشر عمرو بن عثمان بن قَنبر سيبويه - تحقيق. عبد السلام هارون - الهيئة المصرية العامة للكتاب

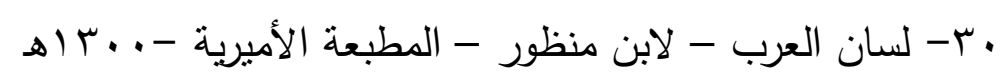

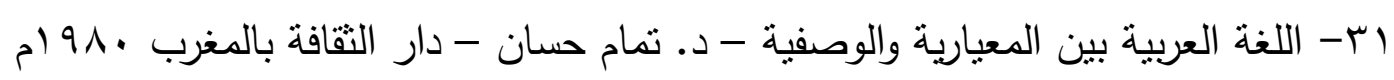

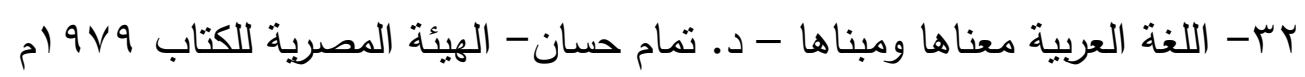
بr- اللغة - فندريس - نرجمة.عبد الحميد الدواخلى - محمد القصاص - الأنجلو المصرية

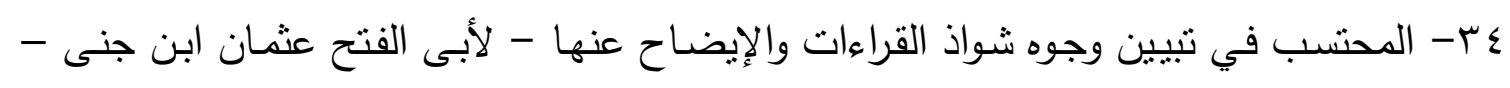

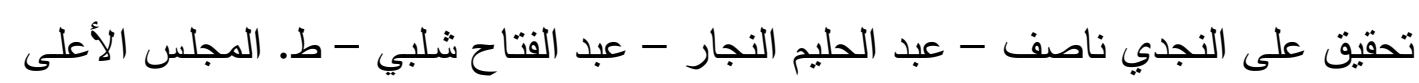

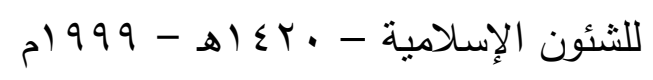


هب - المدخل إلى دراسة النحو العربي على ضوء اللغات السامية - د. عبد المجيد عابدين - دار الطباعة الحديثة

جس- مراتب النحويين - لأبى الطيب اللغوي تحقيق محمد أبو الفضل إبراهيم - دار نهضة مصر VT- المزهر في علوم اللغة وأنواعها - للسيوطي - تحقيق محمد أحمد جاد المولى - على محمد البجاوى - طبعة الحلبي

AT- المستصفى من علم الأصول - لأبى حامد الغزالي - المطبعة الأميرية r Tr اهـ وب- المصباح المنير - للفيومي - المكنبة العلمية بلبنان • ع- المعجم الوسيط - مجمع اللغة العربية بمصر - الطبعة الثالثة اع - مقاييس اللغة - لأحمد بن فارس - تحقيق عبد السلام هارون - ط. عيسي الحلبي الها اهـ م) -

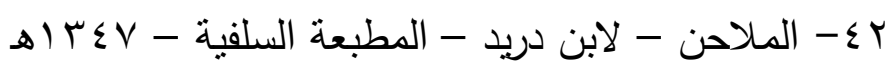

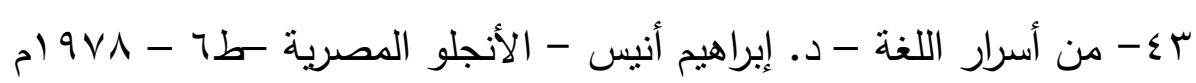
§ - من أصول اللهجات العربية في السودان - د. عبد المجيد عابدين

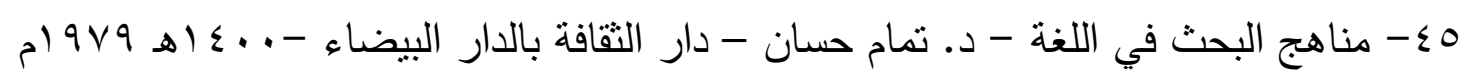
7؟ - المنصف- لأبى الفتح عثمان بن جني - تحقيق :إبراهيم مصطفى - عبد الله أمين - طبعة

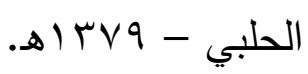

